


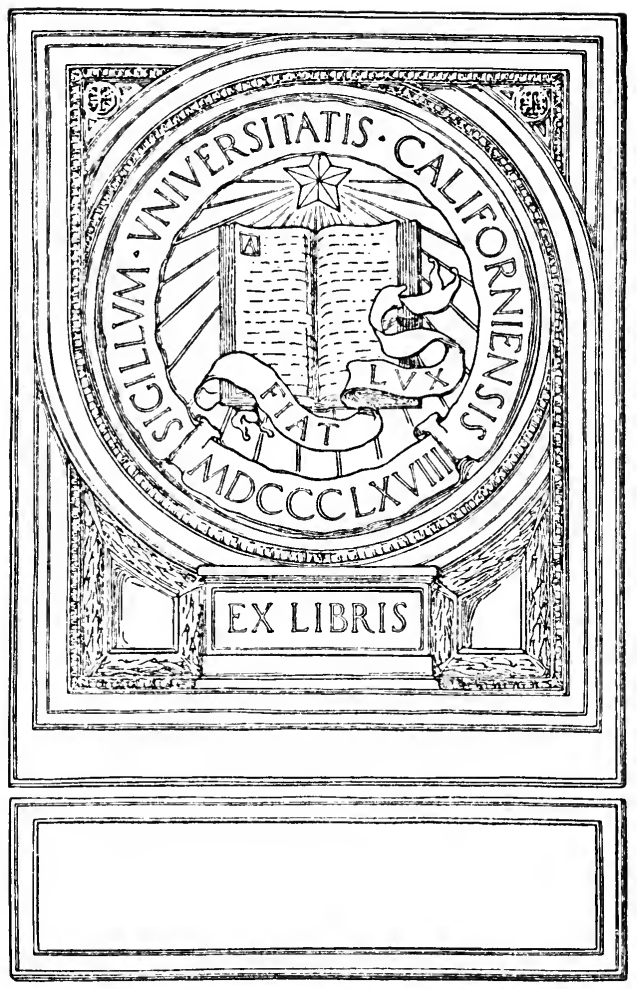





STUDIES IN HISTORY, ECONOMICS AND PUBLIC LAW EDITED BY THE FACULTY OF POLITICAL SCIENCE OF COLUMBIA UNIVERSITY

Volume LXXXIX]

[Number 2

Whole Number 203

\section{THE RETURN OF \\ THE DEMOCRATIC PARTY TO POWER IN 1884}

$\mathrm{BY}$

HARRISON COOK THOMAS, Ph. D.

Instructor in History, DeWitt Clinton High School

New York City

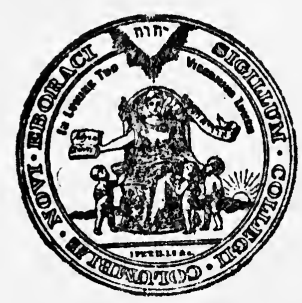

New Work

COLUMBIA UNIVERSITY

LONGMANS, GREEN \& CO., AGENTS

LONDON : P.S. KING \& SON, LTD.

1919 
Copyright, rgig BY

HARRISON COOK THOMAS 


\section{CONTENTS}

\section{CHAPTER I}

\section{Old Parties and New Issues}

Democrats returned because of lack of issues. . . . . . I5

Former issues between the parties. ........... 15

Lack of issues not due to lack of problems . . . . . . . . 16

Economic development $1860-1884 \ldots \ldots . \ldots 16$

Problems arising from economic changes ......... 16

The West. . . . . . . . . . . . . . I7

Relation of government to business ......... I7

Labor problems. . . . . . . . . . . . . 17

Natural resources. . . . . . . . . . . . . 19

No issues on questions admittedly political. . . . . . . 20

Currency . . . . . . . . . . . . . . 20

Sectional lines stronger than those of party ...... 21

History of Democratic attitude toward greenbacks. . . . 2 I

History of Republican attitude toward greenbacks . . . . 22

National banks. . . . . . . . . . . . 22

Indistinctness of party lines shown by state platforms . . . . 23

Parties ends in themselves rather than means ........ 24

Reasons for lack of issues. . . . . . . . . . . , 24

War feeling still alive. ............. 24

Character of leaders. . . . . . . . . . . . 25

Lack of intelligent public opinion......... 25

CHAPTER II

\section{Republican Dissensions}

The Independents. ............... 27

Type of men in movement ........... 27

Not economic reformers. ............ 27

Main aims efficiency and economy. .......... 28 185] 
Campaign of $1872 \ldots \ldots \ldots \ldots \ldots$

Liberal movement . . . . . . . . . . . . . 28

Horace Greeley. . . . . . . . . . . . . . . . . . . . . 29

Grant or Greeley-choice of evils . . . . . . . . . 30

Election results. . . . . . . . . . . . . 3r

Republican scandals lead to landslide of $1874 \ldots \ldots . \ldots 32$

Quarrels over spoils cause split among Republicans. . . . . . . 32

Stalwarts. ................ 33

Half-Breeds. . . . . . . . . . . . . 33

Blaine and Conkling .............. . . 33

Three groups not distinct. . . . . . . . . . . . 34

Grant and Republican nomination in $1876 \ldots . . . . . . .34$

Blaine's early popularity with Independents . . . . . . . 34

Blaine's attack on Jefferson Davis in House . . . . . . . . 35

Blaine's railroad transactions . . . . . . . . . . 35

House committee investigation of sale of Little Rock bonds. . 36

Fisher and Mulligan ......... . . . 36

Blaine's speech in House . . . . . . . . . . . . . 36

Blaine's ruling as speaker in $1869 \ldots . . . . . . .37$

Blaine's activities as bond broker . . . . . . . . . . 37

Failure to make adequate explanation . . . . . . . . 38

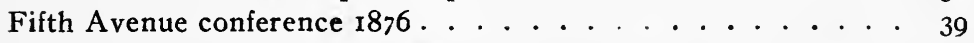

Stalwarts unite with Independents to defeat Blaine's nomination. 39

Tilden nominated by Democrats. . . . . . . . . . . 40

Stalwart and Independent rivalry to control Hayes . . . . . . 4 4 I

Stalwart disgust with Hayes' appointments and policy toward the

South. . . . . . . . . . . . . 42

Accomplishments of Hayes' administration ........ 43

CHAPTER III

Stalwarts and Half-Breeds

Candidates for Republican nomination for Presidency $1880 \ldots . .45$

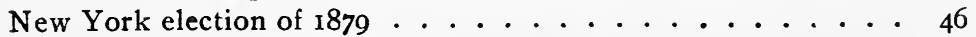

Republican factions............. 46

Democratic factions. . . . . . . . . . . 47

Sherman and Evarts campaign for Conkling's candidate . . . 48

Blaine's strength . . . . . . . . . . . . . 49

Independents oppose Grant and Blaine. . . . . . . . 50

St. Louis anti-third-term convention. . . . . . . . . 50

Republican convention .............. 5 I

Garfield. . . . . . . . . . . . . . . $5^{2}$

Democratic convention . . . . . . . . . . 53 
Platforms. ...................... 54

Campaign of $1880 . \ldots \ldots \ldots \ldots$

Garfield's alleged bargain with Stalwarts. . . . . . 55

Tariff as an issue .............. 55

Republicans gain Presidency and control of Congress . . . 56

Garfield's appointments . . . . . . . . . . . 56

Early harmony destroyed by appointment of Robertson . . . 57

Conkling and Platt resign from the Senate. . . . . . 59

Struggle at Albany over election of their successors . . . . 59

Assassination of Garfield ............ 59

\section{CHAPTER IV}

\section{Arthur's Administration}

Arthur an unexpectedly good President .......... 60

Failure of Republicans to take stand on important questions . . 62

Restriction of Chinese immigration .......... 63

Action during Hayes' administration ......... 63

Act of $1882 \ldots \ldots \ldots \ldots \ldots$

Both parties claim credit for law. .......... 64

Extravagance of Congress. . . . . . . . . . . 64

Business depression makes extravagance more noticeable. . . 65

Condemnation of, in Democratic state platforms ..... 66

Civil service reform as an issue in 1882. . . . . . . . 68

Failure of Congress to act. . . . . . . . . . . 68

State platforms. . . . . . . . . . . . 69

The Irish question as an issue in $1882 \ldots . . . . . .69$

Condemnation of administration for failure to protect American citizens. . . . . . . . . . . 70

State platforms ............... 70

Prohibition question and effect on election ........ . 7I

An issue in various states............ 7I

Attitude of parties toward . . . . . . . . . 7 I

New York election in $1882 \ldots \ldots . \ldots 72$

Democratic factions. . . . . . . . . . . 72

Republican factions............. 73

Cleveland's great victory . . . . . . . . . . . . . 74

Elections of 1882 -reasons for results . . . . . . . . . 75

Arthur's second session of Congress. . . . . . . . . 76

Elections of 1883 ............... . . 76

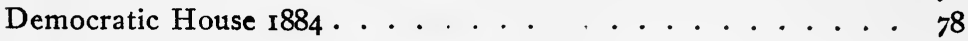

Lack of party policy . . . . . . . . . . . 78

Both parties preparing for Presidential election and refuse to commit themselves. . . . . . . . . . 78 


\section{CHAPTER V}

PAGE

\section{The Issues in i884-Civil Service Reform}

Lack of distinct issues . . . . . . . . . . . . . 8I

Evils of spoils system increases with growth of country . . . . . 8I

Assessment of office-holders. . . . . . . . . . 82

Law of $1876 \ldots \ldots \ldots . \ldots . \ldots . \ldots 8$

Hayes' executive order of $1877 \ldots \ldots . \ldots 83$

Investigation by Senate committee $1879 \ldots \ldots . \ldots 3$

In campaign of $1880 \ldots \ldots \ldots . \ldots . \ldots 84$

In campaign of $1882 . \ldots \ldots \ldots . \ldots . \ldots 85$

Protests of New York Civil Service Reform Association . . . 86

Conviction of General Curtis under act of $1876 \ldots$. . . . 86

Republican attitude toward ............ 87

Star route frauds ............... . . 87

Scandals develop reform spirit. . . . . . . . . . . 88

Slight public interest ............... . 88

Grant's civil service commission. . . . . . . . . . . . 89

Hayes' attitude toward reform. . . . . . . . . . . 89

Growth of reform associations. . . . . . . . . . 90

Garfield's attitude toward reform ........... 90

Arthur urges reform ................ . . 91

Effect of election of 1882 in hastening reform . . . . . . . 92

Pendleton bill ................. 93

Provisions .................. . . 93

Debate in Senate . . . . . . . . . . . . . . 95

Passage by Senate . . . . . . . . . . . . 98

Passage by House . . . . . . . . . . . . . . . . . 98

First civil service commission . . . . . . . . . . . 98

Effect of act on political assessments. . . . . . . . . . 99

Attitude of politicians toward reform. .......... I00

Party platforms on reform in $1884 \ldots \ldots$. . . . . . 02

Importance of attitude of President for success of reform . . . . 103

Blaine's civil service record . . . . . . . . . . . I03

Cleveland's civil service record ............. 104

Importance of civil service reform in campaign of $1884 \ldots \ldots$. . I05

\section{CHAPTER VI}

The Issues in I884-The TARIFF

Tariff much misunderstood as a political issue . . . . . . . I06

High rates originally a war measure. . . . . . . . 107

Bill of $1875 \ldots \ldots \ldots \ldots$. . . . . . . . . . . . . . . . . . . . 
Failure of Democrats to solidify party for tariff reductions, r8751880

PAGE

Tariff in campaign of 1880 .

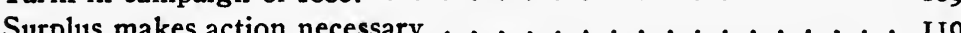

Attempts to reduce surplus by increased appropriations . . . . . II I

Tariff Commission of $1883 \ldots \ldots \ldots$. . . . . . . . II3

Appointment ................. II3

Report................... II4

Bill of $1883 \ldots \ldots \ldots \ldots \ldots$. . . . . . . . . . I15

Arthur's recommendations . . . . . . . . . . II5

Passage. . . . . . . . . . . . . II6

Provisions .................. II

Democratic attempts to make reductions $1884 \ldots \ldots$. . . II

Speakership contest. . . . . . . . . . . . I18

Attitude of President and Secretary of Treasury . . . . . I 18

Morrison bill ............... II9

Provisions ................. . . I19

Defeated by Democratic votes. . . . . . . . . I20

Weakness of Democratic position........... I2I

Effect of business depression of 1884 on tariff as an issue . . . . . I2I

Part played by tariff in Republican nomination. . . . . . . . . I24

Democratic platform on tariff . . . . . . . . . . . I 26

Republican platform on tariff . . . . . . . . . I27

No agreement as to exactly what tariff issue was . . . . . I 28

\section{CHAPTER VII}

The Issues in I884-Minor Issues and Minor Parties

Southern question. . . . . . . . . . . . . . I29

Not a live issue . . . . . . . . . . . . . I29

Investigation by Senate committee of Danville and Copiah outrages ................. I30

Platforms. ................. . I3I

Prejudice against Democrats because of former position . . . I32

Currency .................. . 132

Foreign affairs ................. I33

Questions affecting farmer and workingman ........ I34

Failure of old parties to meet problems. . . . . . . . I34

Farmers' state anti-monopoly and greenback parties . . . . I35

Labor in politics . . . . . . . . . . . I35

Greenback party $1876,1878,1880 \ldots \ldots$. . . . . 135

Effect of business depression on labor party 1884. . . . 136 
Anti-monopoly convention I884 PAGB

Greenback convention I884 . . . . . . . . . . . . . . 138

Benjamin Butler .. . . . . . . . . . . . . . . . I39

Platforms of major parties 1884 .......... . . . . 140

Prohibition ..................... . I I I

Growing importance of movement. . . . . . . . . . . I4I

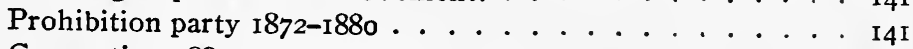

Convention 1884 . . . . . . . . . . . . . . . . . 142

Platform ...................... . . 142

Republican and Democratic platforms on minor issues. . . . . I43

\section{CHAPTER VIII}

\section{The Republican Nomination}

Blaine and Arthur leading candidates ........... I45

Other candidates .................. 145

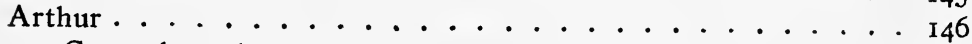

General good record ................ . . . . 146

Sources of weakness . . . . . . . . . . . . I47

Attitude of Independents toward. . . . . . . . . . 147

Blaine . . . . . . . . . . . . . . . . 148

Record in Senate............. 149

Record as Secretary of State. . . . . . . . . . . . . 149

Policy toward Chili and Peru ......... . . 149

Plan for Latin-American peace congress. . . . . . . . I50

Policy toward England . . . . . . . . . . . 152

Vigorous policy unpopular. . . . . . . . . . 155

Attitude toward nomination. . . . . . . . . . . 155

Opposition of Independents to. . . . . . . . . . . . . 156

The Independents. . . . . . . . . . . . . . I57

Formation of conference committee . . . . . . . . 158

Favor Edmunds. . . . . . . . . . . . . ${ }_{158}$

Rules for choosing delegates to convention. . . . . . . . . I59

The convention ................. . . 159

Blaine candidate for temporary chairman defeated . . . . . . 159

Harmony on questions of organization. . . . . . . . . 159

Attempt to bind delegates to support nominee . . . . . . . . 160

Hawley, Sherman, Logan nominated ..... . . . . I6I

Arthur nominated ............... I6I

Blaine nominated. . . . . . . . . . . . . . . 162

Platt seconds Blaine's nomination. . . . . . . . . . 162

Edmunds nominated by Long. . . . . . . . . . . . . 162 
Curtis' speech seconding Edmunds' nomination . . . . . . . I63

Attempts to unite anti-Blaine forces . . . . . . . . . 164

The ballots................... 165

Blaine's nomination fairly won ............ I66

Strength and weakness of Blaine as a candidate ....... I66

Logan nominated for Vice-President. . . . . . . . . . I67

Logan's record and character............. . I67

\section{CHAPTER IX}

\section{The Democratic Nomination}

Multiplicity of weak candidates for Democratic nomination. . . . I69

McDonald . . . . . . . . . . . . . . . I69

Hendricks ..................... I70

Ohio candidates. . . . . . . . . . . . . . I7I

Tilden . . . . . . . . . . . . . . . . . . . I7I

Bayard . . . . . . . . . . . . . I72

Butler . . . . . . . . . . . . . . . . I73

Flower . . . . . . . . . . . . . . . . . . . . I73

Cleveland. . . . . . . . . . . . . . . I73

Mayor of Buffalo . . . . . . . . . . . . . I73

Governor of New York. . . . . . . . . . . I74

Character. . . . . . . . . . . . . . . . I74

Attitude toward party . . . . . . . . . . . I75

Tammany's opposition .............. . . I77

Attitude toward labor . . . . . . . . . . . . I77

Attitude toward corporations . . . . . . . I78

Roman Catholic opposition to. . . . . . . . . . . 179

In New York state convention . . . . . . . . . I80

Attitude of Independents toward. . . . . . . . . . I8t

The convention .................. . . I82

Attempt to defeat unit rule ........... 182

Butler's platform ............... . . I83

Butler's speech defending platform .......... 184

Eulogy of Tilden . . . . . . . . . . . . I86

Nomination of McDonald, Carlisle, Thurman, Hoadly, Bayard,

Randall. . . . . . . . . . . . . 187

Attacks on Cleveland............... I88

Cleveland nominated by Lockwood . . . . . . . . . . I88

Tammany attacks Cleveland. . . . . . . . . . . I89

Genaral Bragg's speech supporting Cleveland . . . . . . I90

Attempt to stampede convention for Hendricks . . . . . . I9I 
Strength and weakness of Cleveland as a candidate $0^{\circ} \cdot 0^{\circ}$ PAOE

Strength and weakness of Cleveland as a candidate . . . . . . I93

Hendricks nominated for Vice-President. . . . . . . . . . . . 193

Hendricks' record and character. . . . . . . . . . . . . I94

\section{CHAPTER $\mathrm{X}$}

\section{The Campaign and the Election}

Candidates' letters of acceptance. . . . . . . . . . I95

National committees ................ . 196

Blaine's speaking tour .... . . . . . . . . . . 196

Cleveland's few speeches .............. . . . I97

Mugwump movement. ............... . 197

Origin of term ................ 197

Organization meeting in New York. . . . . . . . I98

Work of national committee . . . . . . . . . . . I99

Individuals prominent in movement . . . . . . . . 200

Newspapers endorsing . . . . . . . . . . 200

Reformers who refused to join. . . . . . . . . 20I

Attitude of Stalwarts toward. . . . . . . . . . . . 202

Republican tactics toward. ......... . . . 203

Attempt to explain as free-trade movement . . . . . . 204

Blaine's railroad transactions . . . . . . . . . 205

Republican method of meeting attack . . . . . . . . 206

New Mulligan letters... . . . . . . . . . . 206

Other relations with big business brought up against Blaine. . 207

The "millionaire dinner". . . . . . . . . . 208

Attempt to prove Cleveland the enemy of labor . . . . . . 209

Butler's part in campaign . . . . . . . . . . . 209

Charge that Butler was financed by Republicans . . . . . . 2ro

Attack on Cleveland's moral character. . . . . . . . . . 212

Attack on Blaine's family history ............ 214

Southern question. ............. 214

Tariff. .................... . . 215

Democratic attempt to keep in background . . . . . 215

Republicans force it to front. .......... 215

Blaine's part in making it main issue ........ 215

Republicans insincere in declaring it to be main issue ... 217

Prohibition ................... 218

Attempt to get St. John to withdraw . . . . . . . 218

Blaine's attitude toward. . . . . . . . . . 219

Draws strength from Republicans. . . . . . . . . 219

Tammany . . . . . . . . . . . . . . 220

Reluctant support of Cleveland . . . . . . . . 220 
Charge of disloyalty to Cleveland . . . . . . . . 22I

The German vote. . . . . . . . . . . . . . 22I

The Irish vote . . . . . . . . . . . . . . 22 I

"Rum, Romanism and Rebellion". . . . . . . . . 222

October elections . . . . . . . . . . . . . . 223

No definite program offered by either party . . . . . . . . 225

Result of election in doubt. . . . . . . . . . . 225

Republican charges of fraud . . . . . . . . . . 226

Analysis of vote. . . . . . . . . . . . 227

The Congressional election . . . . . . . . . . 228

Reasons for result. . . . . . . . . . . . . 228

Many factors involved. . . . . . . . . . . . 228

Independent movement . . . . . . . . . . . 229

Situation favorable for, in $1884 \ldots \ldots . . . .230$

Reason for Independent distrust of Blaine . . . . . 230

Blaine's strength................. 23I

Part played by business depression in Republican defeat . . . . 23I

\section{CHAPTER XI}

\section{The Democrats in Power}

Problems facing Democrats............. 232

Negative accomplishments of Democrats. . . . . . . 233

Results of war maintained, ........... 233

Pension policy .................. 234

Finances not disturbed ............. . . 235

No scandal. . . . . . . . . . . . . . . . . 236

Civil service reform . . . . . . . . . . . . . . 237

Difficulty of Cleveland's position ... . . . . . 237

Early action of Cleveland pleases reformers . . . . . . 238

Democratic politicians' hostility to ........ . 238

Cleveland yields to party pressure . . . . . . . . . 240

Conflict with Senate over removals . . . . . . . . 24I

Cleveland's impatience with critics. . . . . . . . . 242

Executive order to office-holders $1886 \ldots 243$

Disappointment of Independents. . . . . . . . . . 244

Cleveland's achievements . . . . . . . . . . . . 245

The Tariff . . . . . . . . . . . . . 246

Surplus makes reduction necessary. . . . . . . . 246

Cleveland urges reduction . . . . . . . . . . . 246

Reduction prevented by Democratic votes . . . . . . . 247

Cleveland's message of $1887 \ldots \ldots . \ldots 248$ 
Mills bill

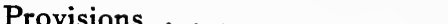

Provisions .......... 250

Minority report . . . . . . . . . . . . . 25I

Debate on bill in Congress . . . . . . . . . 251

Endorsement by Democratic convention $1888 \ldots . . .252$

Passage by House. . . . . . . . . . . . . 252

Republican convention's attack on. . . . . . . . 253

Senate bill ................. . 253

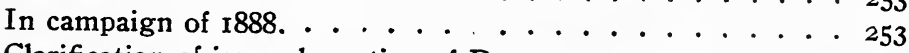

Clarification of issues by action of Democrats . . . . . . 254

Positive achievements of Democrats. . . . . . . . . . 254

Public land policy. . . . . . . . . . . . . . . 254

Navy. . . . . . . . . . . . . . . . . . 255

Laws enacted. . . . . . . . . . . . . . . 255

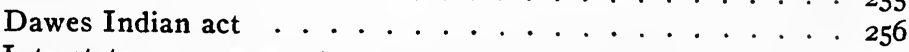

Interstate commerce act. . . . . . . . . . . 256

Labor problems. . . . . . . . . . . . . . . . 257

Lack of party policy toward . . . . . . . . . . . . . . 258

Democratic party not a labor party .......... 258

Main achievements of Democrats negative rather than positive.. 259 Cleveland's part in achievements of Democrats. . . . . . 2 260 Justification for Mugwump movement. . . . . . . . . . . . 260 Effect of return of Democrats to power in uniting North and South. 26r 


\section{CHAPTER I}

\section{Old Parties and New Issues}

On March 4, I885, Grover Cleveland took up his duties as President of the United States, the first Democrat to be trusted with that responsibility since James Buchanan laid it down in the troubled days of March, 186r. In I86I the Democrats had gone out of power on a great issue. They came back to power not on another great issue but because the lack of issues between them and their opponents made the character of the candidates the determining factor for a large number of voters.

The Republican party came into existence with the definite purpose of preventing the extension of slavery, at a time when the Democratic party was committed to permitting or actually encouraging its extension. During the war the Republican party, or Union party as it was called in I864, became the "win the war" party, while the Democrats protested against the exercise of extra-constitutional powers by the federal government and declared that " justice, humanity, liberty, and the public welfare demand that immediate efforts be made for a cessation of hostilities, with a view to an ultimate convention of the States." ${ }^{1}$ At the close of the war there was another realignment on the question of reconstruction. The Republicans, now under the control of the "radical" faction, put through their plan of military reconstruction and negro suffrage, while the

1 Democratic Platform 1864, Stanwood, History of the Presidency, p. 304 . 
Democrats, strengthened by many "win the war" men, were in favor of the Presidential plan of reconstruction and of leaving the question of suffrage to the states. ${ }^{1}$ There were, then, during the period of the war and of reconstructon, clear-cut issues between the parties. But as the problems arising from the war were settled and their settlement accepted, the issues between the parties became more and more indistinct.

The lack of issues was not due to any lack of problems before the nation or to any unanimity of opinion as to the best way of handling these problems. The twenty-four years during which the Democrats had been out of power had been years of great progress throughout the world and especially in the United States. The extension and development of railroads had made available the products of the fertile lands and rich mines of the West. Improvements in ocean shipping had also helped to make the United States the chief source of supply of food products and of raw materials for manufacturing for the countries of Europe. The increased use of steam power and machinery had brought about in manufacturing an industrial revolution hardly less important than the one of half a century before in England. Everything that is commonly summed up in the term "business" had enjoyed a tremendous development. $^{2}$

These changes brought with them new problems. The functions of government were necessarily extended both in number and in kind and there was a constant demand for even further extension. The West, with all the needs of a

${ }^{1}$ Cf. Dunning, "The Second Birth of the Republican Party," in American Historical Review, Oct., I9Io.

The table on the following page shows the growth of the country along various lines during the period. Vide also Bogart, Economic History of the United States, chaps. xxii, xxiv, xxv; Wells, Recent Economic Changes, pp. 5-90. 
new community, was clamorous for attention. Regulation of the railroads on which it was dependent for existence, the establishment of a policy in regard to the public lands that would benefit the actual settler rather than the absentee owner, and expansion of the currency to meet the expansion of business and the consequent increased purchasing power of the dollar were foremost among its demands.

As business became national rather than local in scope the pioneers of business, who had inherited from the pioneers of the previous generation the idea that the public interest was merely a collection of individual interests and that it could best be promoted by stimulating individual economic activity, turned from the state governments to the national government for aid to business in various forms. ${ }^{1}$ The business man and the corporation lawyer came to be common figures in governmental positions. According to the idea of these business men the alliance between business and government ended with the furnishing by the government of the help needed, and business was jealous of any attempt on the part of the government to interfere with what it considered its legitimate functions. Just what privileges business should be given and just how far it should be controlled by the government, had become questions of national importance.

The development of large-scale business and industry necessitated an ever larger proportion of workers dependent on this business and industry for their livelihood. Periods of depression which inevitably came meant suffering for the workers and they began to organize to secure for themselves a larger share of the profits of industry. The "labor vote" had begun to be an element to be considered. Such questions as Chinese exclusion, control of immigration, limita-

${ }^{1}$ Croly, Marcus Alonzo Hanna, chap. xxviii, passim. 
Progress of the United States 1860-I884

From "Progress of the United States" in Statistical Abstract of the United States, I910, pp. 672-723

$$
1860
$$

Population

$31,443,321$

Wealth-total ....... \$16,159,616,000

Wealth-per capita ...

Money in circulation July I .............

Bank clearings .......

Government receipts ${ }^{1}$ ordinary ...........

Government disbursements ${ }^{1}$ ordinary ..

Value of imports ....

Value of exports ....

Number of farms ....

Acreage of farms ${ }^{2}$ improved ..........

Value of farms and farm property .....

Wheat produced(bus.)

Corn produced (bus.)

Cotton produced (500 1b. bales) .........

Wool produced (lbs.)

Value of exports, food stuffs in crude condition and food animals ............

Value of exports of food stuffs partly or wholly manufactured

Value total production minerals ...........

Coal produced (long tons) .............

Iron ore produced (long tons) .......

$\$ 513.93$

$\$ 435,407,252$

$\$ 7,231,143,057$

$\$ 56,054,600$

$\$ 63,200,876$

$\$ 353,616,119$

$\$ 333,576,057$

$2,044,077$

$160,000,000$

$\$ 7,980,493,063$

I73,104,924

$838,792,740$

$3,84 \mathrm{I}, 4 \mathrm{I} 6$

$60,264,913$

$\$ 12,166,447$

$\$ 38,624,949$

$13,044,680$

$2,873,460$
$\$ 266,108,950$

$6,356,998$

$232,500,000$

$\$ 973,382,228$
$\$ 37,182,128,621$

$\$ 333,526,50$ I $^{-}$

$\$ 264,847,637$

$\$ 459,652,883$

$\$ 835,638,658$

$4,008,907$

$280,000,000$

$\$ 12,180,501,538$

$498,549,868$

$1,717,434,543$

$\mathrm{I}, 795,528,000$

$5,682,000$ $300,000,000$

$\$ 193,352,723$

\$194,703,245

$\$ 89,544,435^{3} \quad \$ 364,928,298 \quad \$ 406$, I I 0,405

$63,822,830$

$107,281,742$

1884

54,9 I I,000

$\$ 1,243,925,969$

$\$ 34,092,037,338$

$\$ 348,519,870$

$\$ 244,126,244$

$\$ 457,813,509$

$\$ 740,513,609$

$\$ 130,395,872$

$7,120,362$

1 Fiscal year, ending June 30.

$2 U$. S. Statistical Atlas, 1900, piace no. 128.

s Bogart, Economic History of U. S., p. 323 . 
Pig iron produced

(long tons) ........

Steel produced (long tons) $\ldots . . . \ldots \ldots . .$.

Petroleum produced

(gals.) ............

Miles of railroad in operation ...........

No. of manufacturing establishments .....

No. wage earners in manufacturing .....

Value of manufactured products .......... $\$ 1,885,86 \mathrm{I}, 676 \quad \$ 5,369,579,19 \mathrm{I}$

tation of hours of labor, improvement of conditions of labor, regulation of convict labor, and the establishment of labor bureaus and departments were forced on Congress as well as on the state legislatures. ${ }^{1}$

It had been the policy of the government to make lavish grants of the natural resources of the country to all who asked. There had been no objection to this as long as the resources seemed to be inexhaustible, since the public interest was promoted, for the time at least, by the promotion of private interests. Now, however, there were no longer enough resources to satisfy the demands of all those who wanted them and sound policy demanded that the public itself, rather than any private interest, should derive the benefits from what was left of the public property. Again, the government had given generously of its lands and its credit to encourage the building of railroads, leaving to private enterprise, however, the details of construction. Suffering from the effects of unregulated private control of these public utilities, the people were demanding that the national government take a hand in their regulation.

1 For an interesting account of the early attempts to organize labor by one of the men prominent in the movement vide Powderly, Thirty Years of Labor. 
On none of these questions was there a definite issue between the parties. Their platforms contained either meaningless platitudes which promised no action, or empty acceptances of reforms already forced upon them. Votes in Congress showed a similar lack of party policy. ${ }^{1}$ There was, it is true, but little clarified public sentiment on any of these questions, but the two major political parties had done nothing to develop such a sentiment or to direct that which existed.

The lack of any definite party policy on such questions as these might have been expected, as the dominant political theory of the period, in so far as one existed, was that of laissez faire, the control of private business, using the term in its broadest sense, not being considered a proper field for governmental activity. But even along lines where governmental action was admittedly necessary, there was an equal absence of party policy or of party orthodoxy once a policy had been declared. The politicians of both parties had been for years proclaiming in public their devotion to civil service reform and doing in private all in their power to block it. On questions that involved what is popularly termed "pork", such as appropriations for rivers and harbors, public buildings and pensions, the votes were uniformly non-partisan. ${ }^{2}$

On questions of finance and currency the parties had been in theory at odds at different times, but here too there was great divergence between theory and practice and even between theories in different parts of the country. The Republicans claimed credit for being the party of sound finance and hard money and attacked the Democrats, unjustly the Democrats claimed, for their inflationist and repudiating

${ }^{1}$ McPherson, Handbook of Politics, 1872-1884, gives the party alignment on all important votes during the period.

2 Ibid., passim. 
tendencies and for their hostile attitude toward the national bank act. Neither party, however, could show a consistent record. Sectional and economic lines had always been stronger than party lines. There were in both parties strong elements, mainly from the East, who consistently opposed all attempts at inflation or repudiation; but there were also in both parties strong elements, mainly from the West, who insisted that these things alone would cure the ills of the country. It is true that the Republican party, the party to which most of the Eastern capitalists and bankers belonged, was likely to furnish more votes for any scheme of hard money than the Democrats.

In their platform of I868 the Democrats declared for " one currency for the government and the people, the laborer and the office-holder, the pensioner and the soldier, the producer and the bond-holder," for the taxation of government bonds, and for payment of the obligations of the government in "lawful money" when the law under which they were issued did not expressly provide otherwise. The soft-money men were unable, however, to bring about the nomination of their candidate, Pendleton of Ohio. ${ }^{1}$ In 1872 the Democrats accepted the platform of the Liberal Republicans, which declared that "the public credit must be sacredly maintained" and denounced "repudiation in every form and guise." ${ }^{2}$ Although the Republicans had always announced hard-money principles in their platforms, they had been unable to rally all groups within the party to this standard. They had started to retire the greenbacks at the close of the war but the hostility of the debtor West forced a Republican Congress to pass the act of I868 suspending contraction and that of 1874 attempting inflation.

1 Stanwood, op. cit., p. 322; Dunning, Reconstruction Political and Economic, p. I33.

2 Stanwood, op. cit., p. 343. 
To this latter act, however, President Grant interposed a successful veto. ${ }^{1}$ They delayed for ten years after the war before taking any definite steps toward specie payments and twenty-four Republicans voted against the resumption act of 1875 while the votes of thirty-six were not recorded. ${ }^{2}$ In the Republican National Convention of 1876 the committee on resolutions brought in a financial plank demanding redemption of greenbacks in coin at the earliest possible date "by a continuous and steady progress toward specie payments." The convention refused to replace this by a resolution pledging the party definitely to carry out the provisions of the resumption act already passed. ${ }^{3}$ On various bills introduced in the House from 1877 to 1879 to repeal or emasculate the resumption act, there was always a small number of Republicans voting yea and a larger number who avoided being recorded, so the passage of many of these bills was prevented by the votes of hard-money Democrats. ${ }^{4}$ After resumption was accomplished in 1879 , both parties, so far as their national platforms showed, were in accord in accepting it and equally in accord as to other matters dealing with the currency.

There was the same lack of party alignment in votes concerning the national banks-the West usually voting to limit the power of the banks and the East to sustain or increase it. Neither party had as yet taken a stand on the silver question which was to be so important an issue later. The votes on the Bland-Allison act and on other bills tending in the direction of free silver were not along party lines." In party platforms there had been an issue on the

${ }^{1}$ Dewey, Financial History of the U.S., p. 340.

${ }^{2}$ McPherson, op. cit., 1876, p. 125.

: Proceedings of the National Republican Convention of I876, p. 64

${ }^{4}$ McPherson, op. cit., I876, p. I77, I880, pp. 78, 147, 149.

5Ibid., 1876, p. 182,1878 , p. I28, I880, pp. $46,145,1882$, p. 28,1884 , p. 144 . 
tariff and a great deal was made of it in the campaigns of 1880 and 1884 , but here again the practice of the parties did not follow the theory. ${ }^{1}$

The indistinctness of party lines during this period is brought out strikingly by an examination of party platforms in the different states. The currency and the tariff were the subjects most often treated and the widest divergence in the various state platforms of the same party was common. The Maine Democrats in I874 declared that "an inflated and irredeemable paper currency is among the worst evils that can afflict a community," while the same year the Illinois Democrats opposed any cancellation of greenbacks. By I882 the Maine Democrats had so far forgotten their principles of 1874 as to demand greenbacks and protest against any substitution of national bank notes for them. In I875 the Democrats of New York declared against any further inflation, for a speedy return to specie payments, and that gold and silver should be the only legal tender. The same year Ohio Democrats demanded that the "volume of currency be kept equal to the wants of trade" and that legal tenders should replace bank notes. In 1877 the New York Democrats reaffirmed the currency plank of their platform of 1875 , while the Democrats of Ohio, Iowa and Indiana demanded that there be no contraction of greenbacks and that the resumption act be repealed. In 1878 , while most of the Democratic platforms were calling for a tariff for revenue only, and many in the South for free trade, the Pennsylvania Democrats declared that "the Republicans by reducing the tariff on coal and iron, steel, wool and metals ten percent struck a fatal blow at the interests of Pennsylvania." Similar differences due to local conditions can be found in the state platforms of the Republican party during this period. In general, the platforms of the two 1 Cf. infra, pp. I10, 215 . 
parties in the same states were much more similar than those of the same party in different states. ${ }^{1}$

Differences between political parties are always apt to be more apparent than real. A party organized for the attainment of certain definite ends tends to become, in the minds of many of its followers, an end in itself, and the ideals of the party degenerate into schemes for keeping itself in power. This was especially true of the two great parties in the United States in the years following the Civil War and had become more and more evident in the four years that preceded Cleveland's election.

The Republican party at the close of the war period had a powerful hold on the mind of the North as the party that had abolished slavery and preserved the Union. The Democratic party, on the other hand, was disorganized and discredited. It had a tremendous psychological handicap to overcome before it could hope to be again a powerful national party. Feelings aroused by the war were still strong and emotion was a more potent factor than reason in determining how men would vote. Patriotism was made to cover a multitude of sins. The fact that the Democratic party had been the party of slavery and secession was a premise from which a demagogue could draw the conclusion, and have it generally accepted, that every member of that party was still secretly planning the restoration of slavery and the disruption of the Union. The Democrats felt, therefore, that as long as they were under suspicion of being disloyal they must try to avoid issues rather than make them. The ideal thing would have been for the leaders of both parties to forget the past and to attempt to work out a solution for the new problems before the nation. The easy thing for the Republicans was to keep alive in every

1 McPherson, op. cit., I874-I882, passim. 
a call for a national convention of men with ideas similar to their own to nominate a candidate for the Presidency. The call met with a hearty response from the various groups opposed to the administration. These groups included a large number of the most able and honorable men of the country-statesmen, scholars, lawyers and journalists. They also included a considerable number of disappointed spoilsmen who adopted as their slogan, "Anything to beat Grant," a sentiment which became popular in spite of the efforts of Schurz and his friends to keep the movement on a higher plane. $^{1}$

The convention, which was a mass meeting, adopted a platform which severely arraigned Grant and his friends, demanded reforms in the civil service, and a policy of "universal suffrage and universal amnesty" toward the South. The tariff plank was a disappointment to many but was considered necessary as a concession to the protectionists. It declared that there were differences of opinion on the subject and left it to be decided by the people in the Congressional elections. ${ }^{2}$ When it came to nominating a candidate for the Presidency, the politicians got control and spoiled what chances the movement might have had for success. By a deal between the followers of Gratz Brown and Horace Greeley, to which, however, Greeley himself was not a party, Greeley was nominated. ${ }^{3}$

No one whom they might have chosen could have had better intentions, greater honesty, or greater weaknesses than Greeley. As editor of the New York Tribune since the early forties, he had embraced many "isms", had con-

1 Punning, Reconstruction Pol. and Econ., p. 195; Schurz, Works, vol. ii, p. $36 \mathrm{r}$; Blaine, Twenty Years of Congress, vol. ii, p. 517.

Stan sood, op. cit., p. 34I.

${ }^{3}$ Schurz, Works, vol. ii, pp. 361, 364, 369, 382; Merriam, Life of Samuel Bowles, vol. ii, p. I84; Julian, Political Recollections, p. 339; Bancroft and Dunning, op. cit., p. 338; Rhodes, History of the U. S., vol. vi, p. 422. 
tradicted himself many times, had made many friends and many enemies. He was a national figure of no little influence but he allowed his ambition to get the better of his common sense when he accepted the nomination of such a party on such a platform, especially when it came to him not by the will of those really interested in the movement but by the trick of a group to whom the new party was but a new means for obtaining a share in the spoils. Greeley was not the educated type of reformer that would gain the hearty support of the leaders of the movement. He had, it is true, ever since Lee's surrender, been preaching "universal suffrage and universal amnesty," but here his sympathy with the ideals of the party ended. He had throughout his career been one of the high priests of protection and had never shown any appreciation of the problem of civil service reform. The last grotesque touch was added by the ratification of his nomination by the Democrats, the men to whom for thirty years he had found no epithets too harsh to apply. ${ }^{1}$

Grant was renominated by the Republicans as a matter of course, on a platform which glorified their past record, endorsed the enforcement acts and denounced the Liberals for their disloyalty, but showed the effect of the Liberal movement by declaring for amnesty and civil service reform. $^{2}$ For thoughtful men the choice offered was only a choice of evils. Schurz, Sumner and Trumbull supported Greeley, although without much enthusiasm. ${ }^{3}$ Many others,

'Schurz, Works, vol. ii, p. 386; Merriam, Bowles, vol. ii, p. I9I ; Dunning, Reconst. Pol. and Econ., p. 197; Rhodes, vol. vi, p. 422; Linn, Life of Horace Greeley, passim; Nation, May-Nov., 1872, especially May 9, 16; for Greeley's views on various question vide N. Y. Tribune, especially Dec. 29, 1867, Jan. 4, 7, Feb. 11, 1868, May 31, 1870, Feb. 27, 1871 , May 4, 6, 7, 1872 .

2 Stanwood, op. cit., p. 34I.

schurz, Works, vol. ii, p. 36r et passim. 
while not for the most part doubting Greeley's sincerity, felt that he had the same weaknesses as Grant and that his naiveté would be no match for the wiles of the politicians. They had no desire to exchange a government by the worst element of the Republicans for one by a combination of Republicans and Democrats of the same type. ${ }^{1}$ The $N . Y$. Times, the N. Y. Evening Post, the Nation and Harper's Weekly with Nast's incomparable cartoons supported Grant. Greeley aroused no enthusiasm among Democrats anywhere and many in the North could not bring themselves to support him. ${ }^{2}$ In addition, the business interests were all for Grant and contributed liberally to his campaign fund. ${ }^{3}$ No matter how dishonest or inefficient the administration might be, business was good, and Grant was a "safe" man. No one who had flirted with Fourierism and who held Greeley's views as to the rights of labor could hope to get support of the financial interests. ${ }^{4}$

Greeley carried but seven states, all of them former slave states, while Grant had a popular plurality of more than 750,000 . With this disastrous defeat the Liberal organization disintegrated and as a party ceased to exist. The Liberal idea, however, was not dead, and the Independents remained a force to be reckoned with in future campaigns. The movement had one salutary effect in clarifying the issues, for the Democratic party in accepting the Liberal platform had accepted the results of the war as embodied in the constitution. ${ }^{5}$

${ }^{1}$ Merriam, Bowles, vol. ii, p. I82; Schurz, Works, vol. ii, p. 376; Bancroft and Dunning, op. cit., p. 347.

Julian, Recollections, p. 348.

Rhodes, vol. vi, p. 436; Julian, op. cit., pp. 342, 348.

4 Parton, Life of Horace Greeley, p. I99; N. Y. Times, Aug. I1, I6, Oct. 29, Nov. I, 4, 1872.

${ }^{5}$ Schurz, Works, vol. ii, p. 446. 
The satisfaction of the radicals over their victory was doomed to be short-lived. The "salary grab" act raised a storm of protest, which was increased by the revelations in regard to the Credit Mobilier. Other scandals followed, some of them proven, others only hinted at, until it was the general opinion that every department of the government was inefficient and corrupt from bottom to top. ${ }^{1}$ These scandals together with the hard times caused by the panic of 1873 were too much for the Republicans. In the elections of 1874 the Democrats carried a majority of the states, including Pennsylvania, Ohio, Indiana and Massachusetts and changed the majority in the national House of Representatives from more than one hundred Republican to nearly seventy Democratic. ${ }^{2}$ The Demccratic House, blocked from passing any partisan legislation by a Republican Senate and President, devoted itself to laying bare the sordid record of the Republican administration. One after another of the executive departments was subject to investigation and practically without exception was shown to be honeycombed with inefficiency and corruption.

The scandals in which they became involved were not the only bad effects on the Republicans of the orgy of spoils in which they had been indulging. A party which exists mainly for the spoils of office is bound to suffer from the fact that there are never spoils enough to go around. There grew up in the Republican party during Grant's administrations factions whose origin was due partly to dissatisfaction over the distribution of the patronage and partly to personal jealousies among the leaders. The faction which had the favor of the administration came later to be called the "Stalwarts". The other faction received the name

${ }^{1}$ Dunning, op. cit., chaps. xiv, xv; Rhodes, vol. vii, chap. xl; Hoar, Autobiography of Seventy Years, vol. i, p. 305.

$2 A m$. Ann. Cyc., 1874, articles on the several states. 
"Half-Breeds". Both of these factions differed from the Independents in that they put allegiance to party above all else. With them principles were secondary to party success. The Stalwarts, confident of their power, had little regard for public opinion and were openly scornful of " reform". ${ }^{1}$ It is difficult to say whether the Half-Breeds were more devoted to the interests of the country or merely more hypocritical. They were much more respectful of public opinion and were usually ardent in their protestations of their devotion to " reform ".

The more conspicuous Stalwart leaders were Conkling, Morton, Logan and Cameron. These men had gained power in national affairs through their control of the party organizations in their respective states and they used the power of the administration to maintain their hold in those states. Besides those states - New York, Indiana, Illinois and Pennsylvania - the Stalwarts had complete control of the Republican organizations in the South. The HalfBreeds were stronger in New England and in the middle West. The Half-Breed leader par excellence was James G. Blaine; others were G. F. Hoar, John Sherman and Garfield. ${ }^{3}$

Blaine had entered Congress at about the same time as Conkling. Both men were able, ambitious and intolerant, and a struggle between them for leadership was inevitable. An open break occurred in I866 when they expressed reciprocally uncomplimentary opinions of each other on the floor of the House, after which time they never had personal relations of any kind with each other. ${ }^{4}$ In the opinion of

${ }^{1}$ Conkling, Life of Roscoe Conkling, pp. 538, $55 \mathrm{I}$.

'Schurz, Works, vol. iii, p. 232.

${ }^{3}$ Hoar, Autobiog., vol. i, p. 379; Foulke, Life of O. P. Morton, vol. ii, p. 396; Hamilton (Dodge), Life of James G. Blaine, p. 490.

4 Stanwood, Life of J. G. Blaine, p. 66; Cong. Globe, 39 Cong., I s., pp. $2180,2298$. 
several writers this enmity was the main cause of the lack of harmony in the party. ${ }^{1}$

The line between Stalwarts, Half-Breeds and Independents was, of course, not closely drawn. The groups were continually changing and at any given time it would be difficult to classify many men prominent in the party in any of these three categories. The strength of each varied with the fortunes of the leaders. There was no definite body of political beliefs which made one who held them either a Stalwart or a Half-Breed. Each group was made up of individuals with widely divergent views and abilities who merely acted together for partisan purposes. These three groups can be distinguished, however, throughout the period from Grant to Cleveland and they were the contending factions in the Republican national conventions of 1876 , I880 and 1884 .

In 1876 Grant was in a receptive mood for a third term ${ }^{2}$ but the cry of " Cæasarism" raised by the Democratic politicians, and echoed by some of the Half-Breeds and all the Independents, made his candidacy impossible. Grant favored Conkling as his successor and the betting was in his favor. $^{3}$ The other Stalwart candidate was Morton of Indiana, who controlled a majority of the delegates from the South. ${ }^{*}$ The foremost Half-Breed candidate was Blaine.

Blaine, who was decidedly out of favor with the administration, ${ }^{5}$ seemed likely at first to get Independent support. $\mathrm{He}$ had been in the House since 1863 and had been Speaker from 1869 to 1875 . He had made a reputation as a bril-

${ }^{1}$ Julian, Recollections, p. 277; Sherman, Autobiography, vol. i, p. 550 ; Rogers, Development of the North Since the Civil War, pp. 23, 39.

${ }^{2}$ Appleton's Anmual Cyclopedia, 1875, p. 743.

${ }^{3}$ Foulke, Morton, vol. ii, p. 397.

4 Ibid., p. 389.

${ }^{5}$ Stanwood, Blaine, p. 224. 
liant and hard-working representative. He was an excellent speaker and possessed in a high degree that intangible quality so essential to a successful politician, personal magnetism. Although he was a strong party man and identified closely with the organization, he had worked to moderate the policy of the radicals toward the South and, in spite of some poor committee appointments in the forty-third Congress, he was looked on with favor by the Independents. As the Nation put it, " He has his faults, no doubt, but, compared with Morton, Logan and the present leaders of the Republicans, he seems like an ancient Roman for virtue." 1 His name had been mentioned in connection with the Credit Mobilier scandal but he had been completely absolved by the investigating committee. ${ }^{2} \mathrm{He}$ " killed himself" with the Independents, however, by "too much smartness." ${ }^{3}$ Not relishing the idea of a defensive campaign, he made a bold attempt to discomfit the Democrats and at the same time steal the Stalwart thunder by proposing in an impassioned speech in the House, to exclude Jefferson Davis from the benefits of a bill removing all disabilities remaining under the Fourteenth Amendment, on the ground that Davis was responsible for the horrors of Andersonville. ${ }^{4}$ This gave a new angle to the "bloody shirt" issue and was a shrewd move, but it did not help Blaine's reputation among the thinking men of the country. It was good politics but it was not statesmanship.

On top of this there came a rumor that bonds of the bankrupt Little Rock and Fort Smith Railroad which the Union Pacific Railroad had bought in I87I, at a price far 'above their market value, had belonged to Blaine. Blaine

${ }^{1}$ March II, 1875.

${ }^{2}$ House Report, 42 C., 3 S., no. I7, p. v:

${ }^{3}$ Schurz, Works, vol. iii, p. 218.

${ }^{4}$ Cong. Rec., 44 C., I S., p. 324. 
denied this in a speech in the House, ${ }^{1}$ but the rumor persisted and the whole matter was referred to the judiciary committee. In the hearing before the sub-committee much conflicting testimony was brought out, but Blaine seemed to be having the better of it until the arrival of Warren Fisher and James Mulligan of Boston. Fisher was a business man who had been interested in the promotion of various projects and Blaine had had a long series of financial transactions with him. Mulligan was Fisher's confidential clerk. Mulligan in his testimony declared that he had been told by a director of the Union Pacific that the bonds had belonged to Blaine. In the course of his testimony he mentioned that he had several letters written by Blaine to Fisher. Blaine, on hearing this, secured an adjournment of the hearing, ${ }^{2}$ and that night went to Mulligan's hotel and got possession of the letters, promising to give them back after reading them. He then refused to return them or to deliver them to the committee, presenting a statement by his attorneys that he was entirely within his rights in refusing to surrender them.

Blaine was too shrewd a politician, however, not to realize that, whatever his rights in the matter might be, the country would demand some further explanation. On June $\therefore$, after attacking the judiciary committee for their political motives in a dramatic speech, he read the letters and closed with an accusation that the committee had suppressed an important telegram. ${ }^{4}$ This was a clever stroke, for although the telegram was of little importance and the chairman had been holding it only to verify its authenticity, ${ }^{5}$ it put Blaine

${ }^{1}$ Cong. Rec., 44 C., I S., p. 2724.

${ }^{2}$ Ibid., p. 36r1.

3 The Proceedings of the committee are in House Misc. Doc., $44 \mathrm{C}$., I S., no. 176.

${ }^{4}$ Cong. Rec., 44 C., I S., p. 3602.

"Ibid., p. 5126. 
before the country in the light of being a persecuted man. The hearings before the sub-committee dragged on for a few days but were interrupted by Blaine's sudden illness, and before they were resumed Blaine had been appointed to complete Morrill's term in the Senate. The hearings were dropped for lack of jurisdiction and no report was ever made.

The Republican newspapers treated the matter as though Blaine were the grossly maligned victim of a Democratic plot and as though he had satisfactorily answered all charges. As a matter of fact, Blaine had indulged in a great deal of oratory but had really answered nothing. Although actual corruption was not proven, no one can doubt that Blaine was guilty of conduct unbecoming a Congressman. As Speaker of the House in I 869 he made a ruling which extended the life of the land grant to the Little Rock Railroad. Although this was quite proper at the time, as he had then no interest in the read, a little later we find him sending a copy of the Congressional Globe containing this ruling to Fisher to be used by Fisher to secure him an interest in the enterprise. ${ }^{1}$ Acting under contract with Fisher, he sold bonds of the Little Rock and Fort Smith Railroad to his friends in Maine and took, as his commission, bonuses which would have gone ordinarily to the purchasers of the bonds. When the road fell into financial difficulties and was unable to pay the interest on its bonds, Blaine took these bonds off the hands of the investors, acting, as he said, purely from a feeling of moral responsibility. We can realize how acute this feeling must have been when we consider the probable effect on his political career of the publication of the fact that he had been acting as a broker, and especially of the terms on which he had sold the bonds. He paid back $\$ 168,150$ to his friends in Maine between the spring of $187 \mathrm{r}$ 
and the spring of 1872 , although he made it clear in his correspondence that he did not have the means to pay anywhere near this sum out of his own pocket. He had at that time over $\$ 275,000$ worth of Little Rock bonds which he had received as commission or taken back from his friends. He turned in $\$ 67,000$ worth of these bonds at the reorganization of the road but he never explained what became of the balance. At the same time the Union Pacific, the Atlantic and Pacific and the Missouri, Kansas and Texas Railroads bought from some one approximately $\$ 200,000$ worth of Little Rock bonds, paying for them at par although they were practically worthless in the market. There may be an explanation of these transactions other than the obvious one, but the damning fact for Blaine is that it was never made. ${ }^{1}$

In spite of the proven corruption of Grant's administration few of the Liberals had allied themselves with the Democratic party. Grant's veto of the inflation bill of 1874 encouraged them to believe that the Republican party, in spite of its shortcomings, was more favorable to hard money than the Democratic. Then, too, the return of many of the old-line politicians to power in the Democratic party made it seem hopeless to accomplish anything in civil service reform through that organization. ${ }^{2}$ Although there was always in the background the possibility of a third party, ${ }^{3}$ the best policy seemed to be to try first what could

The question of Blaine's financial cealings played an important part it the campaign of 1884 . My authorities are the government records cited supra; the files of the Nation, N.Y. Times, N.Y. Tribune, for 1876 and 1884 ; Stanwood, Life of Blaine; Hamilton, Blaine; pamphlets published during the campaign of 1884 , e. g. Storey, Blaine's Record, Blaine's Railroad Transactions, The Mulligan Letters, The Charges Against Mr. Blaine Examined by a Republican; and the excellent account in Rhodes, vol. vii, p. I94 et seq.

$\because$ Bancroft and Dunning, Schurz's Political Career, p. 362.

"Ibid., pp. 36ז-364. 
be done with the Republican party. On the initiative of Schurz a conference was held at the Fifth Avenue Hotel in New York, May 15 and 16, " to consider what may be done to prevent the National Election of the Centennial year from becoming a mere choice of evils." ${ }^{1}$ The conference published an address laying down the qualifications which a candidate must have to gain their support. The address made it evident that Blaine was no more in favor than was Conkling or Morton. The favorite of the Independents was Bristow of Kentucky, who had recommended himself by his able and non-partisan management of the affairs of the Treasury department. ${ }^{2}$

In the Republican convention of 1876 the radicals and the Blaine men combined to adopt a platform the dominant note of which was the declaration that the Democratic party had been and still was the party of treason and rebellion. ${ }^{3}$ When it came to the selection of a candidate it was plain that the factions could not be brought together to support any of the men who had been prominently mentioned. Blaine received 285 votes on the first ballot and 308 on the sixth. ${ }^{4}$ He could have been nominated at any time that either the Stalwarts or the Independents were willing. There was considerable Blaine sentiment in Pennsylvania, and to counteract this Cameron had put forward as a candidate Governor Hartranft, who had no chance of being nominated, and secured the passage of a resolution in the state convention that the Pennsylvania delegation should vote solidly for Hartranft as long as his vote kept increasing. ${ }^{5} \quad$ An arrangement was

${ }^{1}$ Schurz, Works, vol. iii, pp. 155, 228.

${ }^{2}$ Hiaworth, The Disputed Election of 1876 , p. I5.

3 Stanwood, Presidency, p. 369.

${ }^{4}$ Proceedings of the Rep. Conv. of 1876, p. 44.

' Rogers, Devclopment of the North, p. 92; Blaine, Twenty Years, vol. ii, p. 568 . 
then made with Morton's managers whereby a few of Morton's votes should be transferred to Hartranft on each ballot in order to keep him in the field. ${ }^{1}$

Governor Hayes of Ohio had been prcposed and received sixty-one votes on the first ballot, the forty-four of Ohio and seventeen scattered. The previous year Hayes had carried Ohio for Governor on a hard-money platform. He had a good record but was not well known outside his own state. He seemed the best that the Independents could hope for, and after Morton had been withdrawn on the seventh ballot and twenty-five of his votes given to Hayes, Bristow's name was withdrawn and the solid vote of Kentucky was cast for Hayes. Cameron brought Pennsylvania into line with twenty-eight votes for Hayes and Conkling furnished sixty-one from New York. ${ }^{2}$ It was evident that the Stalwarts preferred taking their chances with the unknown Hayes rather than with Blaine, whom they knew too well.

The Democrats had their issue ready made for them in the record of Republican misgovernment and they made the most of it. That Samuel J. Tilden should be the candidate was almost a foregone conclusion. Tilden was one of the foremost corporation lawyers of the country and had made a large fortune as the reorganizer of bankrupt railroads. He had had a long training in New York state politics, having been chairman of the Democratic state committee from I866 to I874, the period when Tammany under the leadership of Tweed was at its worst. When the movement against Tweed was started, however, Tilden had aided in his overthrow and was elected governor in 1874 on a reform platform. His efficient and economical administration and his campaign against the canal ring gave him a wide

1 Foulke, Morton, vol. ii, p. 400.

${ }^{2}$ Proceedings of Conv., pp. 107, 108. 
reputation as a reformer. He was a strong supporter of hard money and was acceptable to the business interests. ${ }^{1}$ His chief opponent was Hendricks of Indiana, a politician of the old school and a soft-money man. Tilden was a much more fitting candidate for a reform platform and he was nominated on the second ballot in spite of the protest of John Kelly of Tammany Hall. ${ }^{2}$

With Hayes' nomination the struggle began between the Stalwarts and the Independents to control him. Schurz was in constant communication with him, advising him as to his letter of acceptance and his campaign policy, insisting that the support of the Independents was necessary for his election and that it could be gained only by a hearty endorsement of civil service reform and of a policy of conciliation toward the South. ${ }^{3}$ Hayes' anxiously awaited letter of acceptance was a triumph for the Independents, for he came out with a strong declaration for reform in the civil service and for making an end of the Southern question. ${ }^{4}$ The Stalwarts were determined, however, that Hayes should not be dominated by the reformers. Zachariah Chandler, a notorious spoilsman, was made chairman of the national committee and all the Stalwarts fell into line. Hayes, being too good a politician to refuse support from any quarter, urged the Stalwarts to support him, and in the later part of the campaign even urged the use of the bloody-shirt issue. ${ }^{5}$

${ }^{1}$ Haworth, op. cit., p. 27; Merriam, Bowules, vol. ii, p. 245; Bigelow, Life of S. J. Tilden, vol. i, pp. 241-295.

${ }^{2}$ Procecdings of Nat. Dem. Conz' of 1876, p. 131.

${ }^{3}$ Schurz, Works, vol. iii, pp. 248, 260 et passim.

${ }^{4}$ Procecdings of Conv., p. II5.

${ }^{5}$ Vide letters of Hayes to Conkling and Blaine in Conkling, Life of Conkling, p. 508; Hamilton, Blaine, p. 422 ; vide also Bancroft and Dunning, op. cit., pp. 372, 394. 
With both candidates committed to reform, the Fifth Avenue conferees might well congratulate themselves. Most of them, and the great majority of the Independents, decided to support Hayes, feeling that the Republican party was safer on the financial question and that Tilden was too much of a politician to be trusted. Hendricks, the Democratic candidate for Vice-President, did not add to the strength of the ticket in the minds of the hard-money Independents. ${ }^{1}$ A few, who were normally Republicans, fearing the influence of the Stalwarts over Hayes, supported Tilden. Among them were the two Charles Francis Adamses and Parke Godwin, who had signed the address of the Fifth Avenue conference. ${ }^{2}$

In the violent and dangerous conflict that arose over the result of the election, the Stalwarts continued their strenuous efforts of the campaign to secure the necessary electoral votes for Hayes, ${ }^{3}$ and their surprise and disgust were supreme when his cabinet appointments were announced. Hayes' cabinet was not all that the Independents might have desired, ${ }^{4}$ but from the Stalwart point of view it was hopeless. It included the Half-Breed, John Sherman, as Secretary of the Treasury, a former officer of the Confederate army, David M. Key of Tennessee, as Postmaster-General, and what was still worse from a partisan point of view, Carl Schurz, the bolter, as Secretary of the Interior. When, after an investigation of affairs in Louisiana by a special committee and a conference at Washington with the rival claimants to the governorship of South Carolina, Hayes

${ }^{1}$ Schurz, Works, vol. iii, pp. 259, 26I ; Eaton, Independent Movement, p. 24; Bigelow, Tilden, vol. i, pp. 302, 305.

2 Bigelow, $o p$. cit., i, p. 299; Bancroft and Dunning, op. cit., p. 369; N. Y. Tribune, July 22,1876 .

${ }^{3}$ For an account of the disputed election vide Haworth, op. cit.

"Schurz, Works, vol. iii, pp. $366,376,384$. 
proceeded to withdraw the troops from these two states, the break with the organization was complete. ${ }^{1}$ Blaine declared in the Senate that Hayes' desertion of Packard in Louisiana was an admission that his own claim to the electoral votes of that state was fraudulent, since the same returning board passed on both. ${ }^{2}$ Hayes was spoken of as a traitor and as a man who had climbed to his seat over the dead bodies of the loyal men of the South. ${ }^{3}$

The fact that Hayes had not taken an active part in national affairs and therefore had no factional following to which he must cater, had been an element of strength in attracting to himself the votes of many Independents. But when it came to the actual administration of the government, the lack of a definite body of supporters was a handicap to him. Many of the reformers, once Hayes was inaugurated, felt that their work was, done and gave him no sustained support. ${ }^{4}$ And finally he was handicapped in putting through any constructive legislation by a Democratic House throughout his term and a Democratic Senate during the last two years. Any gratitude which the Democrats might have felt toward him for his policy toward the South was obscured by the fact that they looked upon him as an usurper who had gained his office through fraud. They made strenuous efforts to repeal the various laws for the federal control of elections. Riders which would repeal or emasculate these laws were attached to a number of the appropriation bills during the last two years of Hayes' term. Hayes made liberal use of his veto power and the Democrats were unable to pass the acts over his veto, although they

${ }^{1}$ Sparks, National Development, p. 89; Platt, Autobiog., p. 83.

${ }^{2}$ Cong. Rec., 45 C., 2 S., p. 2047.

${ }^{3}$ Nation, July 12, 1877, Speech of Chandler at Woodstock, Conn.; Speech of Platt at N. Y. Rep. Conv. 1877, in Platt, Autobiog., p. 85.

${ }^{4}$ Nation, Aug. 21, I879. 
forced him to call two special sessions of Congress to make up deficiencies in the appropriations. ${ }^{1}$ This Democratic attack necessarily solidified the Republicans in opposition and partially quieted the criticisms of Hayes from members of his own party.

Although he disappointed the radical civil service reformers, yet, in the opinion of George W. Curtis, Hayes, by a practical demonstration in the New York Post Office and Custom House of what might be accomplished, did more for the reform than any previous President. ${ }^{2}$ Hayes himself considered the pacification of the South and the settlement of the urgent questions of the currency to be the most important problems of his administration, ${ }^{3}$ and his solid achievements along those lines in the face of a hostile Congress must guarantee him an honorable place among our Presidents. From any but a narrow partisan view the Republican party was much stronger in 1880 than in 1876 .

${ }^{1}$ Sparks, op. cit., chap. viii, passim.

${ }^{2}$ Harper's Weekly, Feb. 26, I88I.

${ }^{3}$ Williams, Life of R. B. Hayes, vol. ii, p. I Io. 


\section{CHAPTER III}

\section{Stalwarts and Half-Breeds}

The candidates of the two main factions of the Republican party for the Presidential nomination in 1880 were early in the field. Hayes had announced in his speech of acceptance his determination not to be a candidate for reelection $^{1}$ and the various enmities that he had aroused made any reconsideration on his part impossible. The Stalwart leaders realized that Grant was a stronger candidate than any one else of their group and therefore united on him, maintaining that the valid arguments against a third term applied only to a third consecutive term. The Republicans had been claiming for two years that the attempts of the Democrats to repeal the election laws were nothing less than attempts to break up the Union. ${ }^{2}$ The Stalwarts turned all this to their own advantage by claiming that the crying need of the times was for a "strong man" at Washington, and of course the ideal "strong man" was Grant. ${ }^{3}$ That distinguished warrior and exPresident, who had just returned from a triumphal trip around the world, was easily persuaded to be a candidate. ${ }^{4}$ Blaine had maintained his leadership among the Half-

${ }^{1}$ McPherson, I876, p. 212.

${ }^{2}$ Vide N. Y. Tribune editorials, Aug., Nov., I879, Jan., March, I880, also speeches of Sherman and Evarts in Tribune, Oct. 10, 22, 1879, March 3, I880.

${ }^{3}$ N. Y. Times, Oct. 10, I879; Nation, Oct. 16.

${ }^{4}$ Garland, U. S. Grant, p. 48r. 
Breeds and his candidacy was taken as a matter of course. The New York Tribune had been carefully nursing Blaine's boom by showing the deficiencies of every other candidate. Another Half-Breed candidate was John Sherman. Sherman favored Blaine but had hopes that he might be turned to in case of a deadlock between Blaine and Grant. ${ }^{1}$

The Democrats had developed no pre-eminent leader during their period of control in Congress. The main question with them was whether Tilden would be able either to get another nomination for himself or to dictate that of one of his friends. The Democrats lost no opportunity to assert that the election of 1876 had been stolen and the Republican newspapers, realizing that Tilden, now regarded as a martyr, was the Democrats' strongest candidate, never ceased their attacks on him. ${ }^{2}$

Both parties were keenly interested in the election of a governor in New York in 1879 because of its bearings on both the nominations and election of 1880 . The faction in either party that could nominate and elect its candidate in I879 would have, it was believed, a good chance of repeating the feat in the national election of the following year. ${ }^{3}$ The contest for the Republican nomination had its prelude in Hayes' struggle to put the merit system into effect in the New York custom house, where gross inefficiency and waste had been reported by a special commission. Chester A. Arthur, collector of the port, was Conkling's chief lieutenant in New York state and refused to cooperate in any reform. Alonzo Cornell, the naval officer of the port, was also treasurer of the Republican state committee and was

${ }^{1}$ Sherman Autobiog., vol. ii, p. 766; Blaine, Twenty Years, vol. ii, p. 660.

${ }^{2}$ Alexander, Political History of New York, vol. iii, p. I8o; Bigelow, Tilden, vol. ii, pp. 254, 264.

${ }^{3}$ Sherman, op. cit., vol. ii, p. 748 ; Nation, Aug. 24,$1879 ;$ N. Y. Tribune, Aurg. 25, Nov. 1, 4, 1879 . 
using the custom house as Republican headquarters. Hayes, after suggesting that Arthur resign and offering Cornell the choice of resigning his position either in the federal service or on the state committee without result, sent the nominations of their successors to the Senate. Through the influence of Conkling and Platt the Senate refused to ratify the appointments. After the adjournment of Congress Hayes suspended Arthur and Cornell and appointed Edwin A. Merritt as collector and Silas W. Burt as naval officer in their places. In the next session of Congress they were confirmed after a two months struggle. ${ }^{1}$

In the New York state Republican convention of 1879 Conkling, to show his own power and his contempt for Hayes, backed Cornell for nomination as governor. The Half-Breeds, convinced that they could not nominate one of their own group, supported Cornell against the Independents' choice, George W. Curtis, and the former was nominated. The Independents refused to support Cornell and formed an Independent Republican Committee which issued an address to the Republicans of the state calling on them to scratch Cornell and Soule, the candidate for state engineer, who was identified with the canal ring. ${ }^{2}$

In the Democratic party Tilden and his friends were engaged in a factional fight with Tammany Hall under the leadership of John Kelly. Lucius P. Robinson, who had succeeded Tilden as governor in 1876 , was a Tilden man and Tilden was anxious, for the sake of his own prestige in the party, to have him renominated in I879. Kelly, however, had quarreled with Robinson over a question of patronage and announced that he would not support him for a second

${ }^{1}$ Sparks, op. cit., p. I57; Sherman, op. cit., vol. ii, p. 673; Conkling, op. cit., p. 555; Nation, Dec. I3, I877; Williams, Hayes, vol. ii, p. 77.

'Appleton's Annual Cyclopedia, 1879, p. 679; Eaton, Independent Movement, p. 38; Alexander, op. cit., vol. iii, p. 412; Nation, Sept. II, 18, 1879 . 
term under any circumstances. When it became apparent that the Tilden men controlled the convention by a narrow margin and that Robinson was to be nominated, the Tammany men withdrew in a body and held a convention of their own. The regular convention proceeded to nominate Robinson while the bolters nominated Kelly. ${ }^{1}$ The Democrats and the "scratchers," that is those Republicans who opposed Cornell, charged that Kelly had sold out to the Republicans. $^{2}$

Under these circumstances the campaign was closely and bitterly fought. To counteract the infiuence of the scratchers, Stalwarts and Half-Breeds forgot their differences and worked together for Cornell. Two members of Hayes' cabinet, Evarts and Sherman, went to New York and made speeches for Cornell in which they entirely neglected state issues and waved the bloody shirt in the best Stalwart style. ${ }^{3}$ Sherman in a letter to Silas B. Dutcher, a custom-house employee, "cordially approved" of his taking part in the campaign and declared that he had no objections to government employees making contributions to the campaign fund. " Sherman justified his disregard of Hayes' famous executive $\operatorname{order}^{5}$ and his willingness to support a man whom he had removed from office for inefficiency and neglect of duty by citing the overwhelming necessity for the victory of the Republicans in 1879 if they wished to win in 1880 and " not see all the results of the war overthrown and the constitutional amendments absolutely nullified." " For a

${ }^{1}$ Ann. Cyc., p. 680; Breen, Thirty Years of New York Politics, pp. 58r, 622 et passim.

${ }^{2}$ Nation, Sept. 25, Oct. 2, 1879; N. Y. World, Oct. I7, 20, 24, 1879.

${ }^{3}$ N. Y. papers, Oct., 1879 .

${ }^{4}$ Nation, Oct. 16, 1879 .

${ }^{5}$ Vide infra, p. 83.

'Sherman, Autobiog., vol. ii, p. 748. 
man who had hopes of being a compromise candidate in I88o, it was important not to alienate entirely so powerful a person as Conkling. Cornell's plurality over Robinson was about 40,000 but Kelly polled 77,000 votes that would normally have gone to Robinson. The other Republican candidates were elected by majorities of less than 5,000, excepting Soule, who was defeated by the Democratic candidate for state engineer. ${ }^{1}$ The scratchers asserted that they had polled about 20,000 votes and claimed credit for Soule's defeat.

Considering that the campaign had been fought almost entirely on national lines, these results were not particularly encouraging to either party. The Stalwarts, however, made the best of such prestige as their victory gave them and were able to dominate the New York state Republican convention of 1880 . In spite of Half-Breed and Independent protests, they forced through a resolution heartily endorsing Grant and instructing all delegates for him. ${ }^{2}$ Cameron in Pennsylvania and Logan in Illinois did similar yeoman work and, despite bitter opposition from the Blaine men, sent delegations to Chicago solidly pledged for Grant."

In spite of these reverses the Blaine men found much to encourage them. State conventions showed that Blaine had great strength in the states where the Republican party was strongest. W. H. Robertson, Blaine's chief lieutenant in New York, who had been elected a delegate to the convention, announced in a letter to the Albany Evening Journal that he would not be bound by the instructions of the state convention inasmuch as they were contrary to the rulings of the national convention of 1876 . Three other delegates followed his lead with statements in the state senate that they would not support Grant. ${ }^{4}$
1 Ann. Cyc., 1879, p. 68 r.
'Ibid., I880, p. 573.
'Ibid., pp. 382, 616 .
${ }^{4}$ Ibid., p. 575. 
Hayes' administration had not been bad enough or good enough to keep the Independents united. Edmunds of Vermont was their candidate but he never developed sufficient strength to make him a real contender for the nomination. The most that the Independents could hope to do was to prevent the nomination of any one entirely unacceptable to them. They early recognized the dangers of the Grant boom ${ }^{1}$ and soon, to the great disgust of the Blaine men who had been forming anti-third-term leagues of their own, added Blaine to their list of undesirables. The Independent Republican Committee of New York sent a circular to all delegates to the Republican state convention, pointing out their strength as shown in the campaign of 1879 and announcing that they would support neither Grant nor Blaine. ${ }^{2}$ The Massachusetts Young Republicans and the National Republican League of Philadelphia adopted similar resolutions. ${ }^{3}$ An anti-third-term convention was held in St. Louis May 6 which was attended by several prominent independent Republicans and which received messages of endorsement from independent groups and individuals in all parts of the country. This convention, presided over by ex-Senator John B. Henderson, adopted resolutions demanding "from a party without a master the nomination of a candidate without a stain" and appointed a committee of Ioo which was instructed to meet in New York if Grant were nominated and take such action as seemed best. ${ }^{4}$

The Republicans assembled in Chicago with both Grant and Blaine men claiming victory. The Blaine men gained an important point in the adoption of a rule, reported by

'Schurz, Works, vol. iii, p. 494.

${ }^{2}$ Nation, March 4, 1880.

'Ibid., March 4, II.

4 Official Proceedings of the Anti-Third Term Republican Convention; Ann. Cyc., 1880, p. 694. 
the committee of which Garfield was chairman, which provided that on the roll call of states any delegate might demand that his delegation vote as individuals and have the vote so recorded. ${ }^{1}$ This meant that the unit rule was not to be applied and that the convention would not attempt to enforce instructions given by state conventions. It cost Grant seventeen votes from New York, twenty-three from Pennsylvania and ten from Illinois. On the first ballot Grant received a total of 304 votes, of which 107 came from New York, Pennsylvania and Illinois, nineteen from other northern states and the balance from the South. Blaine received 284, of which but fifty-nine came from the South and the rest mainly from strong Republican states. Sherman had the thirty-four votes of Ohio, ten from other northern states and forty-nine from the South. Edmunds received the ten votes of Vermont and twenty from Massachusetts. Thirty-four ballots were taken without material change. Sherman's votes would have nominated Blaine at any time and he would have been glad to deliver them but was unable to do so. ${ }^{2}$ On the other hand, Sherman felt that Governor Foster, the chairman of the Ohio delegation, who, although he was pledged to Sherman, was known to favor Blaine, had not done all that he might have to push Sherman, when it became evident that Blaine could not be nominated. ${ }^{3}$ Garfield, who made the speech nominating Sherman, has also been charged with being half-hearted in his support, not being able to put the idea of his own nomination out of his mind, ${ }^{4}$ but Sherman himself later absolved Garfield from any charge of double dealing. ${ }^{5}$

${ }^{1}$ Proceedings of the Rep. Nat. Conv'. of 1880, pp. 43, 159.

${ }^{2}$ Sherman, Autobiog., vol. ii, pp. 771, 773; Stanwood, Blaine, p. 226.

Sherman, Autobiog., vol. ii, p. 776.

${ }^{4}$ McClure, Our Presidents, p. $27 \mathrm{I}$.

${ }^{5}$ Sherman, Autobiog., vol. ii, p. 778 . 
It finally became evident that neither of the leading candidates could be nominated. Garfield had received one or two votes on most of the ballots, although he had announced in the convention that he was not a candidate. ${ }^{1}$ On the thirty-fourth ballot Wisconsin gave him sixteen votes, on the thirty-fifth Indiana transferred twenty-seven from Blaine to him, and on the thirty-sixth he received all of the Edmunds votes and the greater part of the Blaine votes, thus securing the nomination. ${ }^{2}$ Grant's Stalwarts never wavered, giving him 306 votes on the final ballot. Conkling was furious, the nomination of Arthur for Vice-President, which was looked upon as a peace offering, doing little to pacify him. ${ }^{3}$

Garfield was one of the better sort of Half-Breeds. He had been prominent in Congress and was well-informed on most public questions. The report of the Poland committee in the Credit Mobilier scandal had implicated him, but his explanations convinced most of his friends at least that his action had been the result of ignorance rather than of evil intention. ${ }^{4}$ The Independents were favorably inclined toward him. The Nation said that although he had had moments of weakness, "he is most honorably associated with every question of importance that has come up in Congress during the past twelve years." ${ }_{5}^{5}$ Garfield's great weakness was his willingness to let party expediency rather than his own judgment of what was right dictate his actions. ${ }^{6}$ He had a reputation within the party of being

${ }^{1}$ Proc. of Conv., p. 269.

2 Ibid., passim; Ann. Cyc., I880, p. 694.

'MoClure, Recollestions of Half a Century, p. I10; Hudson, Random Recollections of an Old Political Reporter, p. 97.

"Rhodes, vol. vii, p. 16.

${ }^{5} \mathrm{June} 17, \mathrm{1880}$; vide also Schurz, Works, vol. iii, p. 507.

- Vide e. g. his letter to Hayes March 2, 1876, in Williams, Hayes, vol. i, p. 428 . 
weak and vacillating, which his friends declared was due to his desire to be fair to all sides, while his enemies attributed it to his devotion to his own selfish interests. ${ }^{1}$

The Democratic convention assembled with the question of what was to be done with Tilden still unsettled. Many felt that the strongest issue would be the charge of fraud in 1876 and that Tilden was the only logical nominee. ${ }^{2}$ Tilden controlled the delegation from New York, but Tammany had refused to attend the state convention, had held one of their own and had sent a contesting delegation to Cincinnati instructed to fight Tilden to a finish. ${ }^{3}$ After a struggle before the committee on credentials, where Kelly declared that Tammany would not support Tilden if nominated, and on the floor of the convention, the Tammany delegates were given seats on the floor but were not allowed to vote. ${ }^{4}$ Tilden's manager announced to the convention that Tilden was not a candidate and that he requested his friends to vote for Payne of Ohio. This was thought to be a trick to feel out Tilden's strength in the convention. After the first ballot had shown that there was no strong demand for him, a letter was read from him to the convention in which he positively declined to run on account of his health and recommended the nomination of Randall of Pennsylvania. $^{5}$ On the first ballot opportunity was taken to honor favorite sons, nineteen different men receiving votes, but on the second all factions united to nominate General Hancock.

After the nomination John Kelly took the platform,

${ }^{1}$ Hoar, Autobiog., vol. i, chap. xxviii; Sherman, Autobiog., vol. ii, p. 807; Platt, Autobiog., p. I25.

${ }^{2}$ Bigelow, Tilden, vol. ii, p. 271; N. Y. Sun, June 22, 1880.

3 Alexander, op. cit., vol. iii, p. 449; Ann. Cyc., I880, p. 573.

4 Official Proceedings of the Nat. Dem. Conv., pp. 43, 49, 51 .

${ }^{5}$ Breen, op. cit., p. 595; Bigelow, Letters and Literary Memorials of S. J. Tilden, vol. ii, p. 599; Proc. of Conv., p. I03. 
announced Tammany's complete satisfaction and promised its loyal support. John R. Fellows, the anti-Tammany leader, then mounted the platform and wrung Kelly's hand while the convention roared its approval. ${ }^{1}$ The reconciliation resulted in but one Democratic ticket being nominated for the New York city offices. The nomination of a Roman Catholic for mayor caused complications, however, which resulted in an unexpectedly small vote for Hancock in New York and Kelly was charged with having betrayed him. ${ }^{2}$

The nomination of Hancock was an attempt to answer the Republican charge of disloyalty and at the same time to capitalize the popularity of a military hero. Hancock's record as a soldier was excellent, not the slightest flaw could be found in his private character, but he had had absolutely no experience in politics and possessed but little knowledge of the problems of government. ${ }^{3}$ )

The platforms of both parties were vague and evasive. The choice offered Independents and others who put actual accomplishment along progressive lines above getting office, was a difficult one. Most of the Independents, having had enough of a military hero in the White House, chose Garfield, although his conduct of the campaign made that choice increasingly difficult. His letter of acceptance was a disappointment. In it he gave but perfunctory approval to civil service reform, practically repudiating what Hayes had done. On other issues left unsettled in the platform he was equally vague. ${ }^{4}$

It was Blaine votes that nominated Garfield and it was

1 Proc. of Conv., p. I2I ; Breen, op. cit., p. 599; Alexander, op. cit., vol. iii, p. 454 ; Ann. Cyc., I880, p. 697.

${ }^{2}$ Breen, op. sit., p. 620; McClure, Our Presidents, p. 278; N. Y. Herald, Nov. 5, I880.

${ }^{3}$ Nation, July I, I880.

${ }^{4}$ Ann. Cyc., I88o, p. 700; Bancroft and Dunning, op. cit., p. 395; Schurz, Works, vol. iv, p. I, et passim. 
Blaine who was Garfield's chief adviser throughout the campaign. ${ }^{1}$ The Stalwarts were at first inclined to sulk and Garfield made strenuous efforts to placate them. ${ }^{2}$ In August a conference between Garfield and the Stalwart leaders was called at the Fifth Avenue Hotel in New York, from which Conkling was conspicuously absent. According to Stalwart accounts Garfield pledged in return for Stalwart support that their wishes "should be paramount with him touching all questions of patronage." $\mathrm{He}$ is also said to have offered Levi P. Morton his choice of an appointment as either Secretary of the Treasury or Ambassador to England in return for his services in taking charge of the finances of the campaign. ${ }^{3}$ Whatever the bargain, the Stalwarts from that time on took an active part in the campaign. Even Grant, in spite of his antipathy to oratory, was persuaded to take the stump for Garfield. Conkling spoke in New York and then made a tour of the Middle West, in the course of which a meeting was arranged between him and Garfield at Garfield's home. At this meeting Garfield is reputed to have said, "Conkling, you have saved me. Whatever man can do for man, that will I do for you."

In the campaign there was little discussion of any real issues. The Republicans started out by painting in lurid colors the dangers of southern domination; out of seventy documents published by the Republican Congressional Committee, twenty-six dealt with some phase of the southern question. This issue soon lagging, Blaine advised that it be dropped." Garfield himself recommended that the tariff should receive more attention, ${ }^{6}$ and during the latter part

1 Hamilton, Blaine, p. 486; Sherman, Autobiog., vol. ii, p. 807.

${ }^{2}$ Conkling, Conkling, p. 278; Andrews, Last Quarter Century, p. 3 I4.

3 Platt, Autobiog., p. 127; Conkling, Conkling, p. 623.

${ }^{4}$ Platt, Autobiog., p. I35; Conkling, Conkling, p. 623.

${ }^{5}$ Hudson, op. cit., p. 212.

'Sherman, Autobiog., vol. ii, p. 787. 
of the campaign it received much more than the circumstances warranted. ${ }^{1}$ The Democrats, after an attempt to stir up excitement with the old cry of fraud, turned a large part of their fire on Garfield's Credit Mobilier record, and as a last-minute argument the celebrated "Morey" letter appeared. This letter, later proven to be a forgery, was supposed to have been written by Garfield and to show his desire to allow the immigration of Chinese laborers for the sake of providing employers with cheap labor. ${ }^{2}$

In the election Garfield received a plurality over Hancock of less than 10,000 in the popular vote, but in the electoral college he had 2I4 votes to I 55 for Hancock. Hancock carried every former slave state and California, $\mathrm{Ne}$ vada and New Jersey. In the Congressional elections the Republicans gained control of the House for the first time since 1873 . As a result of elections by state legislatures, each party had thirty-seven Senators, with Mahone of Virginia classified as a Readjuster and David Davis of Illinois as an Independent. Mahone voted with the Republicans, and this with the vote of the Vice-President assured Republican control. ${ }^{3}$

Garfield's cabinet was an evident attempt to please everybody, and at first he seemed to have succeeded. ${ }^{4}$ Blaine as was expected was Secretary of State. Windom of Minnesota, the Secretary of the Treasury, was another HalfBreed, prominent in the West, who had flirted with the softmoney men enough to be acceptable to them, but who had given assurances of the soundness of his present financial views sufficient to satisfy the East. ${ }^{5}$ Wayne MacVeagh of

${ }^{1}$ Cf. infra, p. Iro.

${ }^{2}$ Sparks, op. cit., pp. 176, 244; N. Y. Times, N. Y. Tribune, July 16, 1884.

${ }^{3}$ McPherson, Handbook, 1882, pp. 115, 186.

'Vide comment of N. Y. papers, March 6-8 and Nation, March to.

${ }^{5}$ Sherman, Autobiog., vol. ii, p. 815. 
Pennsylvania as Attorney-General was a concession to the Independents. James of New York, who was made Postmaster-General, was a Conkling man whose conduct of the New York post office had been such as to make him acceptable to all factions. ${ }^{1}$ Robert T. Lincoln of Illinois, the Secretary of War, was also classed as a Stalwart, but his appointment was generally approved out of respect for his name if nothing more. Neither James nor Lincoln was a man whom Conkling personally would have favored. Kirkwood of Iowa, as Secretary of the Interior, and Hunt of Louisiana, as Secretary of the Navy, were unknown and unobjectionable.

The harmony brought about by these early appointments was, however, to be short-lived. With Blaine in the cabinet and looked upon as "premier," and with Conkling. imperious and quarrelsome, a conflict was inevitable. It came over the New York appointments. Garfield claimed that he told Conkling in a conference that he would make one conspicuous appointment of a friend of Conkling for the sake of party harmony but that future appointments would be on the basis of merit alone. ${ }^{2}$ Conkling claimed that Garfield had definitely promised him that he would consult him before making any New York appointments. ${ }^{3}$ At any rate Garfield's early nominations included that of Levi P. Morton as minister to France and several other Stalwarts as federal marshals and district attorneys. Among these were a number whom Hayes had refused to reappoint because they were inefficient or hostile to civil service reform. ${ }^{4}$ These nominations were supposedly made

${ }^{1}$ Nation, March 10, $188 \mathrm{I} ; N . Y$. Tribune, March 6.

${ }^{3}$ Hoar, Autobiog., vol. ii, p. 56.

${ }^{3}$ Vide Conkling's and Platt's letter of resignation in $A n n . C y c$., 1881, p. 644; article by Boutwell in McClure's Magazine, vol. xiv, p. 86.

${ }^{4} N$. Y. Times, March 30, $188 \mathrm{r}$. 
with the approval of the New York Senators, but it developed later that they had not been consulted and were in fact opposed to at least two of them. Before these were confirmed the nominations of Edwin A. Merritt, who had been collector of the port of New York, for consul-general to London, and of William H. Robertson, Blaine's lieutenant in New York and the man who had led the revolt against Grant in the New York delegation, as Merritt's successor, were sent to the Senate. It has been claimed that Blaine had no hand in this nomination and was opposed to it on grounds of policy, ${ }^{1}$ but this is difficult to believe and was contrary to the general opinion at the time. ${ }^{2}$

The Republicans and Democrats in the Senate were wrangling over organization and adjourning from day to day wthout doing anything, so immediate action was impossible. Conkling, Platt, Arthur, and James united in a letter, which was later endorsed by Governor Cornell, protesting, on grounds of devotion to civil service reform, against Merritt's removal and "earnestly and respectfully" asking that the nomination of Robertson be withdrawn. The Half-Breeds and Democrats in the New York legislature combined to pass a resolution urging the consent of the Senate to Robertson's appointment. Conkling did his best to make a deal with the Democrats to refuse consent, offering, it was reported, to help defeat W. E. Chandler's appointment as Solicitor-General, an appointment which, evidently dictated by Blaine without the approval of MacVeagh, was distasteful to the Democrats because of Chandler's reputation as one of the most conspicuous wavers of the bloody shirt. After nearly two months Garfield, in order to make the issue a clear'one and prevent adjournment

${ }^{1}$ Rogers, Development of the North, p. I42; Boutwell, Reminiscences of Sixty Years, vol. ii, p. 274; Alexander, op. 'cit., vol. iii, p. 469.

2 Vide Nation, Harper's Weekly, Independent, N. Y. papers for March and April, $188 \mathrm{I}$. 
without action, withdrew all nominations except that of Robertson. Conkling and Platt thereupon resigned, stating their position in a long public letter to Governor Cornell. After their resignation Robertson's nomination was confirmed.

The struggle was then transferred to Albany, where the legislature proceeded to the electon of Senators to fill the vacancies. Both Conkling and Platt announced their intention of standing for re-election as a vindication. The Democrats in the state legislature voted for their own candidates and neither faction of the Republicans had enough votes to control the election. The balloting began on May $3^{I}$ and continued until July I without result. Then Platt withdrew, seven Stalwarts deserted and Warner Miller was chosen as Platt's successor. A few days later Elbridge G. Lapham was elected in Conkling's place. ${ }^{1}$

President Garfield was shot by Guiteau on July 2 and died September 19. The assassin declared that he removed the President as a public necessity in order to unite the two factions of the Republican party. ${ }^{2}$ No one believed that any responsible person had any connection with the crime, but the evident fact that it was the result of the bitterness of partisan feeling reacted against the Stalwarts. It doubtless hastened the settlement at Albany and furnished an additional reason for Conkling's permanent retirement as a * national leader. Conkling took up the practice of law in New York city and never again took an active part in politics. His retirement was another step in that disintegration of the Stalwarts which had begun with their defeat in the convention of 1880 .

${ }^{1}$ The best account of the details of the struggle in the Senate and at Albany can be had from the N. Y. newspapers, the Nation and Harper's Weekly, March-July, I88r; vide also Ann. Cyc., I881, p. 644; Platt, Autobiog., p. I39; Conkling, Conkling, p. 637 ; Breen, Thirty Years, p. 648; Sherman, Autobiog., vol. ii, p. 817; Sparks, Nat. Develop., p. I84.

2Sparks, op. cit., p. 192. 


\section{CHAPTER IV}

\section{Arthur's Administration}

The first reaction of many people to the news of Garfield's death was doubtless similar to that of the man who exclaimed, "Chet Arthur President of the United States! Good God!" ' Arthur was known mainly as a bon vivant, a "good mixer" and as Conkling's chief lieutenant in New York. The only public office that he had ever held was that of collector of the port of New York, from which he had been removed by Hayes. He stood in the popular mind for most of the things that were objectionable in politics. Even at the time that Garfield was shot, he was with Conkling and Platt at Albany working for their re-election. ${ }^{2}$ To those, however, who had expected that he would be merely a partisan as President, his administration was a disappointment. His opponents, whether Democrats or Republicans, could find few grounds for legitimate criticism. The Nation declared in 1884 that his administration "will not suffer by comparison with any of its predecessors since Lincoln's. Indeed it is above the average of post-bellum administrations in point of respectability." 3

Arthur's cabinet appointments were such as to allay party prejudice and gain general approval. Although the only member of Garfield's cabinet to be finally retained was Lin-

1 A. D. White, Autobiography, vol. i, p. 193.

${ }^{2}$ Platt, Autobiog., p. 163; Alexarder, op. cit., vol. iii, p. 445; Peck, Twenty Years of the Republic, p. 4; Nation, July 7, 188I.

${ }^{3}$ April 24.

60 
coln, the changes were made gradually and with evident care. Most of the appointees were from the Stalwart wing of the party but they were not prominent politicians. None of them was objectionable and most of them were highly creditable. The poorest appointment was that of W. E. Chandler, a prominent supporter of Blaine, as Secretary of the Navy. Chandler was a notorious spoilsman and bloodyshirt waver and his nomination as Solicitor-General by Garfield had failed of ratification in the Senate. ${ }^{1}$ Arthur's record on removals and appointments to minor positions will stand comparison with that of any of his predecessors. ${ }^{2}$ They did not gain him popularity, however, with any branch of the party. The Stalwarts were disgusted because he did not make a general house-cleaning of Half-Breeds, the retention of Robertson as collector of the port of New York being particularly distasteful to them. ${ }^{3}$ The Half-Breeds felt that Blaine should have been retained and that they should have been given more prominent offices. ${ }^{4}$ The Independents were repelled by a few bad appointments in the customs and internal revenue services. ${ }^{5}$

Arthur's first message to Congress was also reassuring to friends of good government, particularly the parts of it which dealt with the tariff and civil service reform. ${ }^{6}$ It was remarkable in being the first one in forty years that made no mention of the South. ${ }^{7}$

1 Nation, Nov. 2, 1882. For comment on other appointments, vide Nation, Nov. 3, Dec. 15, 22, 1881, March 2, April 13, I882; Wheeler, Sixty Years of American Life, p. I23.

${ }^{2}$ Vide annual message I882; Richardson, Messages and Papers of the Presidents (ed. of 1898 ), vol. viii, p. I47.

${ }^{3}$ Platt, Autobiog., p. I8o; Peck, op. cit., p. 7.

'Boutwell, Reminiscences, vol. ii, p. 275 ; Hoar, Autobiog., vol. i, p. 405.

${ }^{5}$ Nation, April I3, June I, I882.

${ }^{8}$ Richardson, op. cit., vol. viii, p. 37 ; $c f$. also infra, pp. 9I, I13.

${ }^{7}$ Nation, Dec. I5, I881. 
The knowledge that, as a result of the elections of 1880 , the Senate, the House and the Presidency were all to be controlled by the Republicans for the first time since 1874 had been a cause for much rejoicing by that party. ${ }^{1}$ Good politics as well as statesmanship demanded that the Republicans make use of their opportunity and unite on a program of constructive legislation which would make an appeal to the voters strong enough to carry the party safely through the elections of 1882 and pave the way for victory in 1884 . In spite of the fact that factional clamor had been temporarily stilled, at least on the surface, the Republicans failed. The prime reason for their failure was their inability or their unwillingness to take alstand on questions that were important enough to become national issues. The Hayes administration had left no effective issue and Arthur's first Congress developed no new ones.

The tariff question was disposed of in the first session, after considerable oratory, by the appointment of a commission to study the question. ${ }^{2}$ Several bills to reform the civil service were introduced but were allowed to slumber peacefully in committee. Reagan of Texas made an unsuccessful attempt to bring his bill for the regulation of interstate commerce before the House. ${ }^{3}$ The nearest approach to a partisan vote on any question of national importance was that on the bill to extend the charters of national banks. The Democrats by dilatory motions prevented action for several weeks, but on its final passage it received twentytwo Democratic votes in the House and eight in the Senate while many Republicans failed to vote. ${ }^{4}$

${ }^{1} V i d e$ e. g. Letters of Mrs. James G. Blaine, vol. i, p. 180.

${ }^{2} C f$. infra, p. I1 3 .

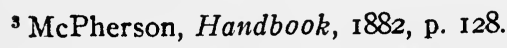

'Ibid., pp. I44, I46; Nation, May 25, I882. 
Both parties hoped to gain advantage by their attitude toward Chinese immigration. The Pacific coast was rabid against the Chinese and its sentiments were shared to a lesser extent by all the states west of the Mississippi. Labor throughout the country had been aroused to fear Chinese competition. Here, then, was an opportunity for some party to make a strong bid for western and labor support and at the same time offend no one except a few "doctrinaires" who believed that the spirit as well as the letter of international treaties should be upheld. The Burlingame treaty of I 868 gave the Chinese full rights of immigration and provided that Chinese residing in the United States should have the same privileges as citizens of the most favored nation. The Democratic Congress in 1879 passed a bill requiring the President to notify the government of China that the provisions of the treaty providing for free immigration would be considerd null and void after July I, I879. Hayes vetoed this bill on the ground that it was an usurpation of the authority of the executive but sent a mission to China to modify the treaty. This mission secured a modification of the treaty which provided that the United States might " regulate, limit or suspend" but might not absolutely prohibit the coming of Chinese, whenever it affected or threatened to affect the interests or endanger the good order of the country. It was further provided that this limitation was to be "reasonable" and to apply only to laborers. Both parties favored restriction of Chinese immigration, according to their platforms of 1880 , and the attempt of the Democrats to show by the Morey letter that Garfield was secretly in favor of unlimited immigration played a prominent part in the closing days of the campaign. ${ }^{1}$

A bill was introduced by the Republicans in Arthur's first

${ }^{1}$ Sparks, National Development, chap. xiv; Ann. Cyc., I882, p. 387. 
Congress prohibiting the immigration of Chinese laborers for twenty years after the passage of the act. The Democrats were determined that the Republicans should get no advantage from it, however, and quite generally supported it. George of Mississippi pointed out in the debate in the House that it was a discrimination on account of race, and was therefore an admission on the part of the Republicans of the justice of the Democratic contention, made for so many years in regard to the negro, that such discrimination was proper. ${ }^{1}$ On its final passage the bill received seven Republican and twenty-two Democratic votes in the Senate, fifteen Republicans and one Democrat voting against it. In the House fifty-eight Republicans and one hundred and nine Democrats voted for it and sixty-two Republicans and four Democrats against it. ${ }^{2}$ This bill was vetoed by President Arthur on the ground that twenty years was not a " reasonable" suspension of the privilege. A similar bill with the time lowered to ten years was then passed and became a law.

In 1882 the Republican platform of California declared that it was a cause for congratulation that the question had finally been settled, " the treaty having been framed by Republican commissioners and ratified and approved by a Republican administration." The California Democrats tendered their thanks "to the Democrats of the Union for a long, earnest and partially successful struggle, through the Democratic Congressmen, with a hostile Republican administration against Chinese immigration. ${ }^{3}$

The one record that the Republicans did make in the first session was that of being one of the most extravagant Congresses in the history of the country. With the tariff left at war-time heights and many of the internal revenue taxes

${ }^{1}$ Cong. Rec., 47 C., I S., p. 1637; Nation, March 16, 30, 1882.

${ }^{2}$ McPherson, i882, pp. 95, 96.

s Ann. Cyc., 1882, pp. 79, 82. 
still in force, a surplus had been piling up in the treasury, and Congress found the reduction of this surplus by means of increased appropriations a pleasant duty. There were large increases in appropriations all along the line, especially in those for pensions and for rivers and harbors. ${ }^{1}$ President Arthur won the approval of the country by vetoing the rivers and harbors bill, asserting that many of the items in it were not "for the common defense or general welfare" and did not " promote commerce among the states." 2 Congress braved public opinion and passed the bill over the veto. The Republicans, being in the majority, were blamed for the extravagance, but votes on appropriations were always non-partisan when all districts were well "cared for." Most of the pension bills were passed without a roll call. Sixty-five Republicans and fifty-one Democrats voted against thirty Republicans and twenty-four Democrats to pass the rivers and harbors bill over the veto in the House, and in the Senate eighteen Republicans and twenty-three Democrats voted against twelve Republicans and three Democrats. $^{3}$

The extravagance of Congress might have gone unrebuked by the voters had not the good times of the past few years abruptly ended. There had been a general failure of crops in I881, both in the United States and in Europe, with resulting high prices of foodstuffs, which had been accentuated by various attempts to corner the market. Labor felt the pinch and demanded higher wages. The crop shortage lowered exports, and gold exports reached the highest mark since 1876 . Money was therefore scarce and the interest rate high. Still another effect of the crop short-

I Cf. infra, p. II2.

${ }^{2}$ Richardson, vol. viii, p. I20; Hoar, Autobiog., vol. ii, p. II2; Nation, Aug. 3, Io, I882.

${ }^{3}$ McPherson, 1882, p. 202. 
age had been to reduce the revenue of railroads and the resulting drop in railroad securities with efforts of speculators to unload caused a general depression in the stock market. More important still was the fact that the means of production of the country had developed faster than the means of consumption and the effects of overproduction were beginning to be felt. Business was poor. The depression was general though not acute. Manufacturers were unable to meet the demands for higher wages and were often glad of an excuse to close down or limit their output. Strikes and lockouts were common. Among the more important labor troubles was a general strike of iron workers west of the Alleghanies and a strike of freight-handlers in New York city. In both these strikes the men were unsuccessful and returned to work with their demands unsatisfied. ${ }^{1}$ When governmental extravagance and high taxes were combined with economic depression and low wages the result was disastrous for the party in power.

The Democrats made the most of the popular feeling in the campaign for the election of Congressmen and state officials in I882, and put resolutions condemning Republican extravagance into practically every state platform. The Michigan Democrats "denounced without distinction of party" all who had voted for the "iniquitous River and Harbor bill." The Connecticut Democrats went so far as to "cordially approve" Arthur's veto. The Republicans themselves were in some cases apologetic as to the appropriations. Those of Kansas endorsed Arthur's veto and the action of the Kansas delegation in voting to sustain it. The New York Republican platform declared that Arthur's " courage in resisting the enactment of the River and Har-

1 Ann. Cyc., I882, pp. I10, 453; 1883, p. 332 ; Paxson, The New Nation, p. 96; Noyes, Forty Years of American Finance, p. 83; Commercial and Financial Chronicle (N. Y.), Jan. 6, 1883. 
bor bill . . . has secured for him the admiration even of his enemies." The California Republicans were alone in having a good word to say for the river and harbor bill, asserting that it had long been Republican policy and was the duty of the federal government "to maintain waterways in their highest standard of usefulness . . . as a constant check on the exorbitant exactions of artificial highways."

Along with the condemnation of extravagance usually went demands for lower taxes, especially for a reduction of the tariff. Both parties demanded tariff revision in Massachusetts, Illinois, Michigan, Nebraska and Iowa, and the Democrats alone in Maine, New Hampshire, Connecticut, Pennsylvania, New York, Ohio, Kansas and Oregon. The tariff planks of the two parties differed in most cases in phraseology rather than in sense. The Republicans usually insisted that in reducing the tariff the protective principle be maintained, while a favorite Democratic formula was for a tariff so fixed that the revenue should not exceed the needs of the government economically administered, and so adjusted as to protect American industry and labor without fostering monopolies. There were, however, a few exceptions. In Maine, New Hampshire and Ohio, the Republicans praised protection with no demand for reduction. Oregon Democrats demanded a tariff for revenue only. Those of Maine did the same and added the assertion that the tariff commission had been packed with protectionists. Michigan Democrats declared themselves " unalterably opposed" to a protective tariff and demanded "immediate and aggressive reform in the direction of free trade." The Democratic platforms of Iowa and Kansas had almost identical planks which declared that "every description of industry should stand or fall on its own merits," and that "the existing protective tariff is an outrageous scheme to 
plunder, and in principle and detail violates every principle of right and justice." 1

The failure of Congress to take any definite steps toward a reform of the civil service was also a source of weakness in the Republican campaign. The evils of the spoils system had been brought vividly before the people by the ConklingGarfield quarrel and Garfield's assassination. The assessment of officeholders, continued in spite of protests, the implication of prominent Republican politicians in the Star Route frauds, ${ }^{2}$ the insolence of Stalwart leaders in New York and Pennsylvania in manipulating conventions and forcing unpopular nominations, and a few flagrant abuses of the power of removal and appointment on the part of Arthur and his subordinates had not helped to allay popular disapproval. Arthur's declaration for reform in his first message, the assertions of such men as Blaine and Harrison, in the course of the campaign, of their devotion to the principle, ${ }^{3}$ and the general adoption of civil-service-reform planks in the state platforms of both parties were indications that the politicians realized that the people had changed their minds about civil service reform even if they had not themselves. The state platform that did not announce civil service reform as one of the main objects of the party's existence was exceptional. There was in most cases extreme vagueness as to the quality and quantity of reform denianded and as to just what steps should be taken to get it. The Massachusetts Republicans were an exception in that they set forth a definite program which included competitive tests for appointment, removals for cause only and promotion by merit. The California Democrats de-

1 Platforms may be found in $A n n . C y c$., I882, articles on the several states.

2 Vide infra, p. 87.

${ }^{3}$ Nation, Sept. I4; Harper's Weekly, Sept. 23, I882. 
clared for the principles embodied in the Pendleton bill introduced at the last session of Congress. In New York both parties declared for reform in their platforms, and in response to a letter from the Civil Service Reform Association both candidates announced their devotion to the principle. Grover Cleveland, the Democratic candidate, definitely endorsed the Pendleton bill. ${ }^{1}$ In Pennsylvania growing dissatisfaction with the high-handed conduct of the Cameron machine had resulted in the candidacy of an independent Republican for state treasurer in $188 \mathrm{I}$ and the formation of an independent organization. This organization was continued in 1882 when the regulars refused to recognize the claims of the independents in the state convention. The independents nominated a state ticket on a platform entirely devoted to civil service reform. ${ }^{2}$ The following extracts from their platform, however, arouse the suspicion that this movement was inspired as much by the desire of the Half-Breeds to chastise the Stalwarts as by zeal for real reform. "The election of Garfield signified to us the triumph of true reform in the civil service . . . the calamity of his assassination has been followed by the overthrow of these reforms in the hands of his successor. ... We declare our purpose to take up the work which fell when Garfield fell." 3

Another factor in the campaign of 1882 was the IrishAmerican vote. The Irish had always largely enrolled in the Democratic party and the Democrats made political capital out of the attitude of the administration toward the Irish question. The Irish in America were in active sympathy with the efforts of the Irish Land League to overthrow the landlords and with the activities of Parnell in

${ }_{1} A n n . C y c$., 1882, p. 609.

${ }^{2}$ Cooper, American Politics, p. 307.

3 Ann. Cyc., I882, p. 678. 
Parliament for home rule. In the course of the trouble several American citizens, mostly naturalized Irishmen, were imprisoned in England under the Coercion act, some of them, it was claimed, on insufficient charges or merely on suspicion. James Russell Lowell, the American ambassador at London, protested in a dignified way against these arrests and secured the release of several against whom there were no definite charges. ${ }^{1}$ His action was not vigorous enough to suit some of the Irish sympathizers in this country, however, and Congress received several petitions for Lowell's recall. The House requested that the President furnish them the correspondence on the subject and the Democrats took the opportunity to attack the administration for laxness in protecting American citizens, on one uccasion introducing a resolution for Lowell's recall. ${ }^{2}$ The board of aldermen of New York city passed a similar resolution. $^{3}$ Democratic newspapers were loud in their denunciations of the administration. A large mass meeting held at Cooper Union in New York city on April 3 was addressed by Mayor Grace, Congressmen Randall and Scranton of Pennsylvania, S. S. Cox of New York, Orth of Indiana, and Senator Jones of Florida. Letters expressing sympathy with the purpose of the meeting were read from Roscoe Conkling, Samuel J. Tilden, Governor Curtin of Pennsylvania and a long list of Democratic Congressmen. A resolution was adopted condemning Lowell's " sycophantic bearing" and declaring that the "honor of the nation demands his recall." 4 The Democratic platforms of New York, Indiana and Illinois contained condemnations of the administration for neglecting to protect American citizens in the United Kingdom.

${ }^{1}$ House Ex. Doc., 47 C., I S., no. 155.

${ }^{2}$ Cong. Rec., 47 C., I S., pp. 765, 3277, 3297.

${ }^{3}$ N. Y. World, March 27, 1882.

'N. Y. World, April 4; Irish World (N. Y.), April I, 15, 1882. 
In 1882 the question of the regulation or prohibition of the liquor traffic had become one of importance and prohibition sentiment was noticeably increasing, especially in the Middle West. This was an important issue in several states and received general attention in the party platforms. The Republicans usually evaded making any statement of their attitude but favored submitting the question to the people. The Democrats, for the most part, came out strongly against any attempt to handle the question by legislation. The assertion, made in many of their state platforms, that sumptuary laws were an unconstitutional and improper infringement on the rights of the individual had the double advantage of being in line with the traditional policy of the party and also of gaining them the support of the liquor interests. Kansas had ratified a constitutional amendment in 1880 prohibiting the manufacture and sale of liquors except for medical, scientific and mechanical purposes, but poor provision had been made for its enforcement and the consumption of liquor in the state had increased. The Republicans of the state renominated Governor St. John on a platform which called for additional legislation to secure rigid enforcement of the act. The Democrats were opposed to prohibition and in a campaign which turned largely upon this issue St. John was defeated although the remainder of the Republican ticket was elected. In Iowa there was a question as to the legality of a recently passed prohibitive amendment to the constitution. The Democrats declared their intention of using every legal means to eliminate the measure from the constitution, while the Republicans made no statement as to prohibition but were supposed to favor it. In Indiana the question was whether the constitutional amendment adopted by the previous legislature should be submitted to the people at a regular or a special election. The Democrats carried the state on the proposition that it 
should be submitted at a regular election. In Illinois the refusal of the Republican convention to endorse a plank favoring a submission of the question to the people led to the formation of a state prohibition party which polled over I I,000 votes in the election. The Illinois Democrats adopted a strong resolution against dealing with the question by law which was praised by the Illinois liquor dealers association as a "manly outspoken resolution." ${ }^{1}$ In Ohic the question was one of licensing the liquor traffic and of enforcing the Sunday closing law, a law providing for license which had passed the previous legislature having been declared unconstitutional. The Republicans stood for license and the Democrats against. The German vote, a strong factor in Ohio, had been largely Republican and it was believed that the Republican attitude toward the liquor question played a large part in turning that vote to the Democrats and enabling them to carry the state in a close election. ${ }^{2}$

The New York election of 1882 is important not only because it resulted in an overwhelming Democratic victory but also because it had important bearing on both the Republican and Democratic nominations for the Presidency in 1884. Factionalism had been rife in both parties since I880. In the elections of $188 \mathrm{I}$ the Republicans elected all but one of their state candidates but lost the assembly as a result of Half-Breed and Stalwart quarrels in the various districts. $^{3}$ A new Democratic organization, known as the County Democracy, had been formed in New York city in an attempt to unite the Democrats into one body which would be free from the control of either Tammany or Irv-

$1 A n n . C y c$., 1882, articles on the several states.

'Sherman, Autobiog., vol. ii, p. 485; Nation, Oct. 19, 1882.

${ }^{3}$ Nation, Nov. 17, 1881 ; Ann. Cyc., I881, p. 656; Alexander, op. cit., vol. iii, p. 486 . 
ing Hall. The County Democracy was recognized as the official organization by the Democratic convention of $188 \mathrm{I}$, but as both the other organizations remained in the field the net result was three warring factions.instead of two. Most of the legislative session was spent in wrangles between the factions over the patronage, but as the state convention of I882 approached talk of harmony was heard on all sides, which finally resulted in dividing the delegates from the city between the three factions. Each faction had its candidate for the gubernatorial nomination but none of them was strong enough to control the convention. Grover Cleveland, who had served as sheriff of Erie county and was then mayor of Buffalo, had been mentioned but had little support at the beginning outside of an enthusiastic delegation from Erie county. It has been charged that his nomination was an accident brought about through a misunderstanding and mutual distrust between the leaders. ${ }^{1}$ At any rate it was received with general approval by Democrats and Independents throughout the state. The Democratic platform contained a strong labor plank, the usual demand for civil service reform and a long indictment of Republican misrule in both state and nation. Cleveland's letter of acceptance cleared up several of the ambiguities of the platform, notably that on civil service reform, and enhanced his popularity. ${ }^{2}$

Republican efforts for harmony were not so successful. Cornell, whose nomination for governor had been forced by Conkling in 1879 , had displeased the Stalwarts by not supporting Platt and Conkling strongly enough in their efforts to vindicate themselves. The breach had been widened by Cornell's veto of a bill regulating the taxation of the ele-

${ }^{1}$ Breen, Thirty Years, p. 680.

'Ann. Cyc., 1882, p. 607; Breen, op. cit., p. 662; Alexander, op. cit., vol. iii, p. 486; Hudson, Recoll., p. 134; N. Y. papers Sept. and Oct., 1882. 
vated railroads of New York city, for which Conkling was attorney. ${ }^{1}$ The Half-Breeds supported Cornell for renomination in I882; the Stalwarts endorsed Folger who had left the New York state bench to become Arthur's Secretary of the Treasury and was understood to be Arthur's candidate. There was much dissatisfaction in the party with the composition of the convention, which was declared not to be representative of the Republicans of the state because of the "rotten borough" system of apportioning delegates. The ill-feeling was aggravated when the nomination of Folger was rushed through with the aid of a forged proxy in the state committee. ${ }^{2}$ So much indignation developed at the methods of the convention that A. B. Hepburn, who had been nominated for Congressman-at-large, refused to accept the nomination and Folger's letter of acceptance sounded almost like an apology. ${ }^{3}$ With only lukewarm support of Folger on the part even of Republican papers, Cleveland received a majority of more than I90,000, the largest majority ever given a candidate for governor in any state. ${ }^{4}$

The elections resulted in an overwhelming Democratic victory throughout the country. Maine, New Hampshire and Nebraska elected Republican governors, but in the other thirteen states where gubernatorial elections were held, including New York, Pennsylvania, Massachusetts, Connecticut, Michigan, Kansas, Colorado, California and Nevada, the Democrats were successful. In Illinois, Indiana and Ohio, where no governor was elected, the Democrats elected other state officers and gained members of Congress. ${ }^{5}$ The

1 Ann. Cyc., I882, p. 600; Alexander, op. cit., vol. iii, pp. 479, 493.

${ }^{2}$ Nation, Sept. 28, Oct. I5, 1882.

"Alexander, op. cit., vol. iii, p. 492 ; Ann. Cyc., 1882, p. 600.

'Harper's Weekly, Nov. 18, 1882.

5 Ann. Cyc., I882, passim. 
Republicans might explain the result in New York by the fact that it was normally a Democratic state and that the huge vote was a rebuke to Arthur for interference in state politics. ${ }^{1}$ Pattison's 40,000 majority in Pennsylvania could be laid at the door of the independent movement. The election of a Democratic governor with the balance of the state ticket Republican in Massachusetts could be explained by Butler's personal popularity. A similar result in Kansas and Michigan might be due to fusion between Democrats and Greenbackers in Michigan and to the opposition of the liquor interests to St. John in Kansas. But all the explanations could not alter the fact that the Democrats had gained seventy-one seats in the House of Representatives. A large number of prominent Republican Congressmen were defeated. Out of fifty-seven of the Republican chairmen of committees appointed by Speaker Keifer in the forty-seventh Congress, only twenty-three were returned. ${ }^{2}$

Causes of political failure or success are always hard to isolate. Many minor issues both national and local complicated the situation in 1882 and contributed to the result. Hard times, disgust with Republican boss domination, Republican extravagance, their failure to reduce taxation, their indifference to civil service reform, the temperance question, the Irish trouble, all doubtless played some part. ${ }^{3}$ Above all these, however, was the fact that there were no great issues between the parties. The Republicans had no program on the questions before the country that would hold their supporters together. Platforms of the two parties were practically identical in many states. Under these circumstances many voters took the opportunity to rebuke

${ }^{1}$ N. Y. Tribune, Nov. 18, 1882.

${ }^{2}$ Nation, Nov. I6, 1882.

${ }^{3}$ Cf. Cooper, op. cit., p. 299. 
the Republicans on the theory that the Democrats could do little worse. ${ }^{1}$

Arthur's message to the second session of the fortyseventh Congress, which assembled in December, I882, dealt mainly with the necessity for reform in the revenue and the civil service. With the results of the November elections fresh in their memory, the Republicans took up these questions, determined to forestall action by the Democrats and to make whatever political capital they could for themselves. Debate on these subjects and on the appropriation bills took up the greater part of the session. ${ }^{2}$ The appropriation bills for the session dropped from the record total of $\$ 25 \mathrm{I}, 000,000$ for 1883 to $\$ 187,000,000$ for $\mathrm{I} 884$. No appropriation was made for rivers and harbors. ${ }^{3}$ Arthur called attention in his message to the need for legislation to repeal the silver coinage act, to provide for counting the electoral vote, to provide for the presidential succession and to provide a new bankruptcy law. The questions of encouragement for the merchant marine, of the control of interstate commerce and of national aid to education were also recommended for the consideration of Congress. ${ }^{*} \mathrm{Al}$ though bills were introduced dealing with all these subjects, nothing definite was accomplished.

I 883 was an off year politically in most states, but where elections were held they were on the whole encouraging to the Republicans. An exception was Ohio, where the Democrats, after a close and hard-fought campaign, were successful in electing a governor and other state officers and in gaining control of both houses of the legislature. There were in Ohio no clear-cut issues between the parties. The

${ }^{1}$ Nation, Nov. 9, 16, 1882.

${ }^{2}$ Vide infra, pp. 93, I16.

${ }^{3}$ U. S. Stat. Abst., I885, p. 4.

4 Richardson, vol. viii, p. 126 . 
liquor question dominated the campaign. Two constitutional amendments were submitted to the voters; the first, which was endorsed by both parties, would give the legislature power to regulate and license the liquor traffic, the second provided for total prohibition. Both failed, as neither received a majority of all the votes cast in the election. The Democratic success was attributed to the strength of the liquor interests, which had more confidence in the friendliness of the Democrats. The desire of many Republicans to rebuke their party for failure to take a more definite stand on the question also affected the vote. ${ }^{1}$ New Jersey elected a Democratic governor by a normal majority. In New York the Democrats elected their state ticket of minor offices with the exception of secretary of state, but their majorities of the previous year were greatly reduced, and partly due to factional fights among the Democrats, the Republicans gained control of both houses of the legislature. $^{2}$ In Massachusetts, Butler was defeated for re-election by Robinson, the Republican candidate. In Pennsylvania the Republican factions united and elected their candidates for state treasurer and auditor. The Republicans made large gains in Connecticut, and carried Iowa, Nebraska and Minnesota by their customary majorities. In the campaign for the control of the Virginia legislature, the Democrats made strenuous efforts and defeated Mahone's

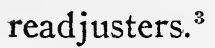

One reason for the Republican gains was that the machine remained in the background, particularly in New York and Pennsylvania. There were no scandals about political assessments and no attempts at federal interference. The

1 Nation, Oct. I8, I883; Ann. Cyc., I883, p. 816.

2 Breen, op. cit., p. 688.

3 Nation, N. Y. Times, N. Y. Tribune, Oct. and Nov., I883; Ann. Cyc., I883, passim. 
independent vote, in the main, seemed to have returned to the Republicans. The principal reason was, however, that the Democrats had no issues. They seemed determined not to take a definite stand on anything except that "the Republicans must go," and to trust that dissatisfaction with the Republicans would be sufficient to carry them into power and keep them there.

In the forty-eighth Congress, which met for the first time in December, I883, the Democrats had a majority of seventy-five over all opponents in the House but the Republicans still controlled the Senate. The minds of the members of both parties were turned toward the approaching Presidential election and all action was subordinated to it. One method of preparing for it would have been the enactment of a definite program of legislation by each house which, even if it failed to become law, would have made the issues clear. Another method, and the one adopted, was to avoid all partisan questions and the taking of any definite stand as a party, leaving the campaign to be made on party loyalty and attacks on the general wickedness of the opposing party.

The President in his annual message recommended that no further reduction be made in the tariff until the effects of the existing law could be determined. He urged that provision be made for keeping up the volume of the national bank notes, that the trade dollar be retired from circulation, that the navy be enlarged, that a territorial government for Alaska be organized, that attention be given to the question of providing for federal aid to education, that the Presidential succession be provided for, that the problem of control of interstate commerce be taken up and that some provision be made for preserving the national forests. ${ }^{1}$

The only strictly partisan legislation attempted was for a

${ }^{1}$ Richardson, vol. viii, p. I70. 
further reduction of the tariff. The House spent a large part of the session debating this question, but as the Democrats were unable to unite their own party on any program, nothing was accomplished. ${ }^{1}$ The actual accomplishments of the session in legislation were confined to a bill providing civil government for Alaska, a bill to encourage American shipping, the creation of a bureau of labor in the department of the interior and a bureau of animal industry in the department of agriculture, a supplementary Chinese exclusion act to provide for the better enforcement of the act of the previous year, and the repeal of the test act. All these bills were non-partisan in character, the votes both for and against being quite evenly distributed between the parties. ${ }^{2}$

General pension bills to provide pensions for all veterans, of the Mexican and various Indian wars received support from both sides but were not passed. The House passed, almost unanimously, a resolution that all public lands "heretofore granted and subject to forfeiture because of non-fulfilment of conditions" be forfeited, and in accordance with this several bills were passed providing for forfeiture of particular grants, but the Senate took no action on them. ${ }^{3}$ A bill prohibiting the importation of contract labor also passed the House but was not acted upon by the Senate. ${ }^{4}$ The Senate passed a bill for federal aid to common schools and also a bill permitting national banks to issue notes to the full amount of the bonds held by them, both of which failed through lack of action in the House. ${ }^{5}$ Another bill passed by the Senate providing increases in the navy.

1 Vide infra, p. IIg.

${ }^{2}$ McPherson, 1884, passim; Ann. Cyc., 1884, p. 185.

${ }^{3} \mathrm{McPherson,} \mathrm{I884,} \mathrm{p.} 155$.

${ }^{4}$ Ibid., p. 193 .

${ }^{5}$ Ibid., pp. 142, 147. 
had support from both sides although the opposition was almost entirely Democratic. The House failed to agree, however, and finally a naval appropriation bill was passed appropriating fifty per cent of the amount of the previous year. ${ }^{1}$ The Senate's electoral count bill also failed when the House refused to agree. ${ }^{2}$ The Democrats were attacked by the eastern papers for their unsound financial views when they struck out of the bill for the redemption of the trade dollar the provision that the amount of silver in the redeemed dollars should be deducted from the $\$ 2,000$,000 per month provided for in the Bland-Allison act. ${ }^{3}$ On none of the measures here mentioned, however, was there a strict party alignment, nor was there any serious effort on the part of party leaders to make them party issues. The most that can be said is that the parties showed tendencies in certain directions, and that certain questions, while having support from both parties, could expect more from one than from the other.

The general feeling of the country on the adjournment of Congress was that it had done nothing very bad. It kept the appropriations within respectable limits, permitted no big jobs and prevented some bad legislation. ${ }^{4}$ Although its accomplishments were small, the absence of scandals made it compare favorably with many of its predecessors. The action of both parties made it evident that they were determined to go into the Presidential campaign with no big issues clearly drawn. It meant that the character of the candidates would be the factor of greatest importance in determining the votes of the great majority of those who did not vote blindly for a party emblem.

$1 \mathrm{McPherson,} \mathrm{I884,} \mathrm{p.} 165$.

'Ibid., p. I32.

'Nation, March 10, 1884.

4 N. Y. Tribune, N. Y. Times, July 8; Nation, July 10. 


\section{CHAPTER V}

The Issues in i884-Civil Service Reform

There was in 1884 no issue on which the parties were clearly divided, either by their records or their formal statements, no issue on which one party outlined a definite program which the other challenged with an opposite one. The voter who wished by his vote to register his approval or disapproval of a certain policy had no obvious choice, but must weigh many considerations where probabilities rather than certainties were involved. Two questions that had claimed a great deal of the attention of Congress and in which there was considerable public interest were civil service reform and the tariff. On neither of these was the issue between the parties clearly drawn. Both parties claimed to be the friends of civil service reform. The Republicans, while admitting the necessity for a reduction of the tariff, declared that the principle of protection was safe only in their hands as the Democrats were aiming at free trade, a statement which the Democrats emphatically denied. A review of the previous action of the parties on these two questions and of their attitude toward them will be useful in determining to what extent they influenced the election.

The abuses of the spoils system which had been notorious before the war had been augmented by the great extension of governmental activities and the multiplication of civil servants. During the long period when the Republicans were in control with no effective opposition, conditions had growing steadily worse. The report of the Senate committee 26r] 
on the reform bill of 1883 declared that the main evil of the existing system was, that with the growth and expansion of the country the appointing power was unable to give the necessary personal attention to appointments, and what attention was given was a distraction from more important duties. Also that political influences had come to dominate and subordinate all other considerations in making appointments, and that offices had come to be sought as so many charities furnishing support to the needy and exacting a return of partisan service. ${ }^{1}$ Besides the inefficiency in the service that resulted from the existing method of making appointments, the indirect effects were even more serious. By use of patronage the professional politician was able to build up his local organization and keep himself in power, excluding anyone who was really interested in or capable of solving the problems before the country.

Another phase of the spoils system that had attracted even more attention than inefficiency in the service or favoritism in making appointments was the assessment of officeholders for campaign purposes. The system of raising campaign funds by contributions from office-holders, which, though nominally voluntary, were really made under fear of dismissal, had originated in the early days of the spoils system and had been practiced by both parties in state and local as well as in national politics. ${ }^{2}$ It was left, however. to the Republican Congressional Committee to systematize thoroughly the procedure so far as concerned federal officeholders. To meet this evil an act was passed by Congress in 1876 which provided that "all executive officers or employees of the United States not appointed by the President, with the advice and consent of the Senate, are

${ }^{1}$ Sen. Rep., 47 C., I S., no. 576.

${ }^{2}$ Lalor, Cyclopedia of Political Science, vol. i, p. 153. 
prohibited from requesting, giving, or receiving from any other officer or employee of the government any money or property or other thing of value for political purposes." 1 On June 22, I877, President Hayes issued an executive order forbidding officers of the government to take any active part in politics and adding "No assessment for political purposes should be allowed." 2 This order added to the disgust which most of the politicians of his party felt for Hayes. They declared it to be an infringement of the personal liberty and rights of citizenship of office-holders and it was not strictly enforced.)

The Senate in 1879 authorized a special committee to investigate the question of political assessments. This committee reported that in the campaign for the Congressional election of 1878 the Republican Congressional Committee sent the following letter to every official and employee of the United States with a salary of $\$ 1000$ or more: ${ }^{3}$

This committee call with confidence upon you, as a Republican, for such contributions in money as you may be willing to make, hoping that it will not be less than $\$-$.

The Committee deem it proper in thus appealing to Republicans generally, to inform those who happen to be in Federal employ that there will be no objection in any official quarter to such voluntary contribution. . . . Please make prompt and favorable response to this letter and remit at once.

Gorham, the secretary of the committee, testified that the part of the letter promising no objection from any official quarter had been submitted to President Hayes and approved by him. ${ }^{4}$ A second letter was sent as a reminder to

1 Ann. Cyc., I882, p. 694.

2 Richardson, vol. vii, p. 450.

${ }^{3}$ Sen. Rep., 46 C., I \& 2 S., no. 427 , p. 2.

I Ibid., p. 20. 
those who had not responded informing them that arrangements had been made to have a representative of the committee at the German American National Bank after office hours for the convenience of those who wished to contribute. Still a third letter was sent to those who had not paid up. ${ }^{1}$ A representative of the committee was sent into the offices of the various departments with a letter from Jay A. Hubbell, the chairman of the committee, authorizing him to receive subscriptions and asking that "every facility be afforded him in the prosecution of his labors." 2 According to Gorham's testimony a total of $\$ 106,000$ was raised by the committee for the campaign, of which all but $\$ 13,000$ came from office-holders.

In I880 similar letters were sent out by the same committee of which Hubbell was still chairman. It is estimated that at least $\$ 100,000$ was raised in this way. ${ }^{3}$ Garfield's attitude toward this method of raising campaign funds is shown in a letter to Hubbell under date of Aug. 23, I880, which came out in connection with Garfield's dispute with Conkling. In this letter he said, "Please tell Brady I hope he will give us all the assistance possible. I think he can help effectively," and asked to be told "how the departments are generally doing." " The Brady referred to was Thomas W. Brady, Second Assistant Postmaster-General, who had charge of the collections among employees of the Post Office department and who was later implicated in the Star Route frauds.

In addition to the contributions requested by the Con-

1 Sen. Rep., 46 C., I \& 2 S., no. 427, p. 3.

'I bid., p. 33 .

'Lalor, op. cit., vol. i, p. I53.

4 Rep. Camp. Textbook, I882, p. I03. Other letters showing that Garfield was not averse to political assessments were published in the N. Y. Herald, Dec. I I, I882. 
gressional Committee, the federal office-holders in most of the states were "given an opportunity" to contribute a second time by their respective state committees. The New York state committee sent three letters, each more insistent than the preceding, and finally sent to each department head a list of those who had not contributed, saying, "You will find opposite each name the amount yet due. The total unpaid at this date and due from the employees of your office, therefore, appears to be $\$$ - Your immediate attention to this matter is very important." ${ }^{1}$

In 1882 the Republican Congressional Committee sent out a letter similar to that of the two previous campaigns. State committees also again sent letters asking for contributions from federal employees. Reformers raised a strong protest against these attempts to hold up office-holders, ${ }^{2}$ and in the Senate, Pendleton of Ohio introduced a resolution for an investigation by the committee on civil service and retrenchment, ${ }^{3}$ but in spite of these protests the Congressional Committee sent a second letter more importunate than the first. (This letter expressed the surprise of the committee at the failure to respond to the first and continued:

Great political battles can not be won in this way. This committee can not hope to succeed in the pending struggle, if those most directly benefited by success are unwilling or neglect to aid in a substantial manner. We are on the skirmish line of r884. . . . Unless you think that our grand old party ought not to succeed help it now. . . . It is hoped that by return mail you will send a voluntary contribution equal to $2 \%$ of your annual compensation, as a substantial proof of your earnest desire for the success of the Republican party this fall. . ...

${ }^{1}$ Lalor, op. cit., vol. i, p. I54.

${ }^{2}$ Nation, June 15, 22, 29, I882.

s Ann. Cyc., I882, p. I5I.

${ }^{4}$ Ann. Cyc., I882, p. 694. 
The New York Civil Service Reform Association sent a circular letter to federal employees warning them that they were liable, under the act of 1876 , to fine and removal if they contributed. Hubbell, in reply, sent a letter to G. W. Curtis, president of the New York association, challenging the association to get an opinion from the Attorney General as to the legality of the contributions, or to fight it out in the courts. Curtis in his reply declared that the contributions were not voluntary and that the Congressional Committee had no right to send out letters without authorization by the party. The New York association then offered to bring a test case into court, but Hubbell refused and accused Curtis and the association of being accomplices of the bulldozers of the South. Finally, Secretary of the Treasury Folger in a letter to an employee of the Treasury department said that he had received an opinion from the Attorney General that Congressmen were not officers of the United States in the meaning of the statute of 1876 , and that contributions to the committee were therefore legal. A statement was later given out by Arthur that no one should be removed or injured in any way for refusing to contribute. ${ }^{1}$

General Newton M. Curtis, an official of the United States Treasury department, was chairman of the New York state Republican committee in I88I and had received contributions from federal office-holders in New York state. The New York Civil Service Reform Association had him indicted in the U. S. Circuit Court, which found him guilty under the statute of 1876 and fined him \$10oo. Curtis appealed to the Supreme Court on the ground that the law was unconstitutional, but the Supreme Court upheld the constitutionality of the law and sustained the decision. ${ }^{2}$

1 Richardson, vol. viii, p. I47; Rep. Camp. Textbook, I882, p. 94; Nation, June and July, 1882.

2 Ann. Cyc., 1882, p. 694; Wheeler, Sixty Years, p. 267. 
The Republicans were quite willing to admit that contributions had been asked for, but declared that they were entirely voluntary and that no one had been removed for failing to contribute. The Democrats found it difficult to prove that there had been dismissals for this reason alone. The Republican Campaign Text-book for 1882, published by the Congressional Committee, attacked the law of 1876 as a trick of the Confederate brigadiers " to defeat if possible the Republican majority in the approaching Presidential campaign by depriving them of the sinews of war . . ." and declared that any attempt to limit a man's right to contribute was an intolerable infringement of his personal liberty. It then proceeded to give a history of campaign contributions, showing that all the prominent men in the party, including Hayes and Garfield, had favored contributions, but that all Republicans, particularly the members of the Congressional Committee, were aghast at the idea that there was anything compulsory about them. After devoting several pages to proving that contributions were quite proper, it went on to show that they had "their rise in the corrupt party practice of the Democratic party." 1

Another thing that helped to arouse the country to the need for reform was the disclosure of frauds in the Post Office department. On certain routes mail was carried by private contract. These routes were known as the "Star Routes." James as Postmaster General began an investigation as to the method of letting these contracts and disclosed what appeared to be a conspiracy between Brady, the Second Assistant Postmaster-General, ex-Senator Dorsey of Arkansas and various subordinates in the executive departments, to increase the number of star routes and increase the compensation for old ones, the profits being divided between the members of the ring. Brady resigned and several sub- 
ordinates either resigned or were removed. Indictments against Brady, Dorsey and several others were found by the grand jury of the District of Columbia. The defendants took advantage of every technicality to obstruct the trial, attempts to bribe the jury were charged, and after one disagreement all except one minor defendant were discharged. ${ }^{1}$

The assessment of office-holders, the inefficiency and corruption of many civil servants and the generally low moral tone of political life convinced a considerable group that the main issue in American politics was reform of the civil service. As is likely to be the case with reformers, many of them overestimated the efficacy of a statute to regenerate the country. The more moderate ones realized that it would take something more than the passage of a law to correct such a state of affairs as was shown to exist by the investigations of the Sanborn contracts, the whiskey ring and the other scandals of the Grant administration. They believed, however, that a law which would prohibit the levy of political assessments, provide competitive examinations for entrance to the service and provide for promotion by merit, would go a long way toward improving the conduct of the nation's business by breaking the hold of the politicians. These reformers included a few of the men of both parties who were prominent in national affairs and a larger number of educated, able and patriotic private citizens. They were the nucleus of the Independents in the Republican party.

The general public was but little interested in the question. The voters had grown up knowing of no other way of appointing public officers except the spoils system and were slow to appreciate its evils. The politicians of both parties realized that a real reform of the civil service would

1 Ann. Cyc., I882, p. 753, 1883, p. 777 ; Sparks, Nat. Develop., p. 188. 
be a blow at their power. At first, knowing that the public had little interest in the reform, they were frankly hostile and ridiculed it openly. As the reformers by constant propaganda began to arouse public interest, most of the politicians found it expedient to do a certain amount of lip service to the principle while doing all in their power to prevent any reform in practice. When at last public sentiment became too strong to be ignored and the reform bill was passed, the parties vied with each other in claiming credit for it.

The first step toward reform was the excellent report on the civil service from the joint select committee on retrenchment of the fortieth Congress, written by Jenckes of Rhode Island, published in I868. ${ }^{1}$ Thanks to the activities of the reformers and to the favorable attitude of Grant, a commission was created in $187 \mathrm{I}$ which established rules providing for competitive examinations for entrance to the service. These rules were applied to the departments at Washington and to the federal offices in New York city. The commission, however, encountered much opposition from the politicians and was not always given the support which it should have had from Grant. After two years Congress failed to make any appropriations for the commission, and Grant, after putting the responsibility up to Congress, ${ }^{2}$ allowed the whole system of competitive examinations to lapse. ${ }^{3}$

In the campaign of 1876 civil service reform was given attention in the platforms of both parties and both candidates were committed to it by their records and their statements during the campaign. ${ }^{4}$ Although the actual accom-

${ }^{1}$ House Rep., 40 C., 2 S., no. 47.

${ }^{2}$ Richardson, vol. vii, p. 301.

${ }^{3}$ Fish, The Civil Service and the Patronage, p. 212; Dunning, Reconst. Pol. and Econ., p. 243; Report on Pendleton bill, Sen. Rep., 47 C., 2 S., no. 576 , p. v.

${ }^{4}$ Vide supra, pp. 40, 4I. 
plishments of the Hayes administration in this respect were small, a valuable demonstration of the practicability of the reform was made in the New York custom house and post office and in the Interior department. The quarrel over the changes in the New York custom house ${ }^{1}$ attracted considerable attention to the movement and various societies were formed to study the reform and work for its adoption. The New York association, one of the strongest and most active, was formed in 1877 and others sprang up in Boston, Philadelphia, Milwaukee and San Francisco. In August, I88I, a national league of civil service reform associations was formed at Newport with George W. Curtis as President. $^{2}$ The membership in these associations was relatively small but it included many men of ability and influence. Several newspapers and magazines, notably Harper's Weekly and the Nation, endorsed the movement and hundreds of articles were printed in these magazines and separately as pamphlets.

Garfield's record in Congress on civil service reform and his expressed attitude toward it ${ }^{3}$ were important factors in turning the Independents to him in the convention of I880. His later lukewarmness in his letter of acceptance and his statements during the campaign were disappointing. ${ }^{4}$ As practical a politician as John Sherman found it necessary to warn him that he could not afford to ignore the question. ${ }^{5}$ In his inaugural address Garfield declared that he would at the proper time ask Congress to fix the tenure of the minor offices and also to prescribe the grounds on which removals might be made. ${ }^{6}$ It was evi-

1 Vide supra, p. 46.

${ }^{2}$ Wheeler, op. cit., p. 264; Fish, op. cit., p. 217.

${ }^{3}$ Vide article by Garfield in Atlantic Monthly, July, 1877.

4 Schurz, Works, vol. iv, p. I, letter of Schurz to Garfield.

"Sherman, Autobiog., vol. ii, p. 779.

6 Richardson, vol. viii, p. 6. 
dently his intention to shift the burden to Congress and let the reformers get what they might there. ${ }^{1}$ Before his first Congress assembled, however, Garfield had fallen, a victim, many believed, to the spoils system. ${ }^{2}$

Arthur's remarks on the civil service in his first message were an agreeable surprise to friends of reform. He declared that he was "impressed with the grave importance of correcting the evils which inhere in the present methods of appointment." He pointed out certain features of the English system which he did not think were adaptable to the United States but declared that he would feel bound to give his approval "to a statute incorporating all the essential features of the English system." $\mathrm{He}$ recommended that at least an appropriation of $\$ 25,000$ be made to enable him to carry out the law of 187 I which was still on the statute books. $^{3}$

In spite of Arthur's recommendations nothing was accomplished during the first session of the forty-seventh Congress. Pendleton of Ohio introduced a reform bill in the Senate drafted by Dorman B. Eaton and other members of the New York Civil Service Reform Association." Hearings were held by the committee and the bill was reported favorably, but no action was taken. ${ }^{5}$ The House in committee of the whole voted down the proposition to appropriate $\$ 25,000$ for the enforcement of the act of I87I, but later had a partial change of heart and voted to appropriate $\$ 15,000 .^{6}$ Considerable attention was devoted to the reform in the state platforms of $1882^{7}$ and the re-

${ }^{1}$ Vide letter of Garfield to Blaine, Hamilton, Blaine, p. 493.

${ }^{2}$ Vide speech of Pendleton in Senate Cong. Rec., 47 C., I S., p. 79.

${ }^{3}$ Richardson, vol. viii, p. 60.

${ }^{4}$ Wheeler, op. cit., p. 276.

${ }^{5}$ Cong. Rec., 47 C., I S., pp. 20, 23, 57, 47 I.

'Nation, July 13, 20, 1882.

${ }^{\top}$ Vide supra, p. 68. 
formers declared that the Republicans were defeated because of their lack of action on the question.

In his message to Congress in December, 1882, Arthur showed that he, in part at least, shared this view. "The people of the country," he said, "apparently without distinction of party, have in various ways and upon frequent occasions given expression to their earnest wish for prompt and definite action. In my judgment such action should no longer be postponed." Assuring Congress of his hearty cooperation in any measures for the correction of the evils in the existing method of appointment, he specifically recommended the Pendleton bill then before the Senate. As to details, he said that the term for all officials should be definite and the tenure stable and that "neither should be regulated by zeal in the service of party or fidelity to the fortunes of an individual." $\mathrm{He}$ also felt called upon to defend himself from the charge of making an unusual number of removals for partisan reasons and gave a summary of appointments and removals made by Hayes, Garfield and himself. As to political assessments, he said, referring to his announcement of the previous summer that giving or refusing to give to campaign funds would not affect the status of any office-holder :

I acted upon the view . . . that a public officer should be as absolutely free as any other citizen to give or withhold a contribution for the aid of the political party of his choice. It has, however, been urged, and doubtless not without foundation in fact, that by solicitation of official superiors and by other modes such contributions have at times been obtained from persons whose only motive for giving them has been the fear of what might befall them if they refused. It goes without saying that such contributions are not voluntary, and in my judgment their collection should be prohibited by law. A bill which will suppress them will receive my cordial approval. ${ }^{1}$

${ }^{1}$ Richardson, vol. viii, p. I45. 
Senator Beck introduced a resolution to refer the quesion of political assessments to the judiciary committee with instructions to investigate and bring in a bill. Hale of Maine offered an amendment to the resolution that would widen the scope of the investigation to take in the campaign funds of both parties and especially the amounts contributed by liquor dealers and brewers. After considerable partisan debate the resolution with the amendment was referred to the judiciary committee, which, however, took no action, as the Pendleton bill contained a section prohibiting political

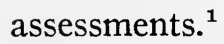

The first week of the session Pendleton called up his bill which had been reported the previous session and it was discussed nearly every day until its passage on December 27. The committee in its report on the bill summed up the evils in the existing system and declared that, "The spectacle exhibited of the Chief Magistrate of this great nation, feeding, like a keeper, his flock, the hungry, clamorous, crowding, jostling multitude which daily gathers around the dispenser of patronage, is humiliating to the patriotic citizen interested alone in national progress and grandeur." 2

The Pendleton bill as originally reported to the Senate provided for a commission of five to be appointed by the President, two of whom were to be persons holding other positions in the government service, and no more than three of whom were to be members of the same political party. The duties of the commission were to aid the President by formulating rules which were, as far as possible, to provide for open competitive examinations for entrance to the public services classified in the bill, for appointment from those passing with the highest grade, for apportion-

${ }^{1}$ Cong. Rec., 47 C., 2 S., pp. 23, 72.

'Sen. Rep., 47 C., I S., no. 576. 
ment of appointments as nearly as practicable among the states according to population, for entrance to the service at the lowest grade only and for promotion from lower to higher grades on merit. No one was to be under any obligation to contribute to campaign funds and no coercion was to be used. The act was to apply only to classified lists of clerks in the executive departments at Washington and in custom houses and post offices where their number was more than fifty, but the President was given power to add other classes of employees. The provision that entrance was to be at the lowest grade only, the higher being filled by promotion, immediately drew the attack of the Democrats, who declared that it was a scheme to keep the Democrats out of the higher offices, and it was dropped. The number of commissioners was changed from five to three, none of whom was to hold other government position. In considering the section on political assessments, an amendment providing that no employee of the government might either solicit or give money for any political purpose was voted down by a strictly partisan vote-eighteen Democrats against twenty-four Republicans - but an amendment was unanimously adopted which provided that no government employee of any kind should either solicit or receive political contributions, that no person should solicit or receive such contributions in a room in use by the government and that no one was to be favored or injured for giving or failing to give. Various other amendments were introduced by the Democrats with the purpose of displacing Republicans already in the service but they failed of adoption. Among them was one to declare vacant all positions in the services affected by the law and to compel those holding these positions to compete with new applicants for appointment. Another provided that if two or more persons were equally qualified for a position, until there was approxi- 
mately an equal share of offices between the parties, all appointments should be made from the party having fewer offices. ${ }^{1}$

The bill had supporters on both sides of the Senate. Pendleton introduced it with a vigorous attack on the spoils system, charging that the existing civil service was inefficient, extravagant and corrupt. He admitted that the bill was not perfect and applied to but few offices, but justified it as an experiment. ${ }^{2}$ Other Democrats who spoke for the bill were Jones of Florida, Morgan of Alabama, George of Mississippi and Bayard of Delaware. ${ }^{3}$ Prominent among the Republicans who spoke for the bill were Hawley of Connecticut, the chairman of the committee, Hoar of Massachusetts, Miller of New York and Sherman of Ohio. ${ }^{4}$ The open opposition was mainly from the Democratic side. Maxey of Texas, Call of Florida, Brown of Georgia, Vest and Cockrell of Missouri, Williams of Kentucky and Voorhees of Indiana attacked it as undemocratic, unnecessary, unjust to Democrats, and a fraud. ${ }^{5}$ Many Republicans, especially some of the Stalwarts, were no more pleased with the bill than were the Democrats, but for the most part they maintained a discreet silence. The two Senators from Kansas, Plumb and Ingalls, were the only two Republicans to speak against the bill, and Plumb voted for it on its final passage. Mahone, the Virginia Readjuster, who usually voted with the Stalwarts, spoke against the bill, ${ }^{6}$ but Logan, one of the Stalwart leaders, spoke for it. $^{7}$

${ }^{1}$ Cong. Rec., 47 C., 2 S., pp. 200-867, passim; McPherson, I884, p. II.

${ }^{2}$ Cong. Rec., 47 C., 2 S., p. 204.

I Ibid., pp. 281, 324, 360, 468.

'Ibid., pp. 24I, 273, 282, 362 .

5 Ibid., pp. 277, 355, 359, 461, 497, 505, 597.

- Ibid., p. 560.

${ }^{7}$ Ibid., pp. 246, 326. 
Most of the speeches, especially those against the bill, were frankly partisan. The Democrats assumed in their remarks that they were going to win in I884 and were openly opposed to any plan which would not replace with Democrats the Republicans who had enjoyed the spoils for more than twenty years. They took occasion to rake up all the old scandals of Republican administration and characterized Republican zeal for reform as death-bed repentance. The Republicans, they said, were not so anxious for reform as they were to save what they could from the wreck. Some of the Republicans, notably Hoar and Miller, admitted the justice of the Democratic attacks, but maintained that the spoils system was really a source of weakness to a party and appealed to the Democrats to be patriotic enough to forego their chances for spoils. ${ }^{1}$

Pendleton, in his opening speech, declared that the election of 1882 had been a Republican defeat rather than a Democratic victory, and that the passage of the bill would be the best thing that could happen to the Democratic party. Brown of Georgia declared that the mandate of the election had been to turn the Republicans out and not to pass a reform bill. ${ }^{2}$ George of Mississippi answered Brown, saying that his (Brown's) policy would put the Democrats in the same position on the question in which the Republicans were and that unless the Democrats showed their sincere desire for reform, there would be no spoils for them to distribute in $1884^{3}$ Williams of Kentucky said that he was in favor of a clean sweep of Republican office-holders.

I am for a house cleaning from garret to cellar. I am for ferreting out all these old rats who have been in the Treasury

${ }^{1}$ Cong. Rec., 47 C., 2 S., pp. 273, 282.

${ }^{2}$ Ibid., pp. 277, 597.

sIbid., p. 28r. 
so long that they know where the ripest cheeses are, and the best kind of cheeses too. I am for pouring water into their holes and bringing the last one of them from the bottom of his berth. The only way to reform is to put a good honest Democratic President in, in 1884; then turn on the hose and give him a good hickory broom and tell him to sweep the dirt away. ${ }^{1}$

The most scathing attack on the bill was made by Voorhees of Indiana. He praised the spoils system as being the only really democratic one, and declared that the bill was dishonest in design and would be useless in practice. $\mathrm{He}$ ridiculed the whole idea of competitive examinations and proposed the following amendment, which he assured the Senate was not an attempt to burlesque the bill, as the bill was "in itself so complete a burlesque that nothing could add to it in that respect." ${ }_{2}$

That all applicants for appointment as commissioners under this act, shall as a prerequisite to their appointment, undergo a public examination before a committee composed of five practical school teachers, not more than three of whom shall be males, who shall be selected for that purpose by the Commissioner of Education, and the object of such examination shall be to ascertain, first, the competency of said applicants to make a sensible and suitable examination of other applicants for office touching their qualifications in reading, writing, arithmetic, and English grammar; second, the business habits and associations of such applicants for appointment as commissioners, and whether they consider a knowledge of the interior of Africa, the headwaters of the Amazon, the isothermal line, the Monroe doctrine, and the momentum of a body of known weight moving with a given velocity, necessary to the proper discharge of clerical work in the civil service of the Government; and provided further, that such

\footnotetext{
1 Cong. Rec., 47 C., 2 S., p. 505.

${ }^{2}$ Ibid., p. 611.
} 
Senators and Members of Congress as desire to avoid the trouble and responsibility of recommending their constituents for appointment in the civil service of the Government shall be permitted to be present and propound questions at the examinations provided for in this amendment. ${ }^{1}$

The bill passed the Senate by a vote of thirty-eight to five. The affirmative vote included thirteen Democrats, while those voting in the negative were all Democrats. Thirteen Republicans and nineteen Democrats failed to vote. $^{2}$

In the House the bill was reported by unanimous consent and the previous question was carried, in spite of some Democratic opposition, without the usual discussion in committee of the whole. In the one-hour debate that was allowed, Reagan of Texas, a Democrat, attacked the bill as a sham, asserting that it would accomplish no real reform. Herbert of Alabama, a Democrat, said that the bill was of little account but was a step in the right direction. He charged that the Republicans had shut off debate to avoid having their record shown. ${ }^{3}$ On its final passage the bill received the votes of one hundred and two Republicans, forty-nine Democrats and four Nationals. Seven Republicans, thirty-nine Democrats and one National voted against it. The eighty-seven not voting in the House included forty-three Republicans and forty-one Democrats.

Arthur's appointment of Dorman B. Eaton of New York, John M. Gregory of Illinois and Leroy D. Thoman of Ohio as the first civil service commission was received with approval by the friends of the reform. Silas D. Burt, who

1 Cong. Rec., 47 C., 2 S., p. 497.

McPherson, 1884, p. I5.

${ }^{3}$ Cong. Rec., 47 C., 2 S., p. 862.

4 Ibid., p. 867; McPherson, I884, p. 16. 
as naval officer of the port of New York had installed reforms, was appointed to the position of chief examiner, but refused. It was charged that the appointment had been offered him as a means of putting a spoilsman in his place in the New York custom house. ${ }^{1}$ E. O. Graves of the Treasury department also refused the appointment, which was finally accepted by Charles Lyman. The commission immediately proceeded to draft rules, which were approved by the President. In his annual message of December. 1883, Arthur reported that eleven customs districts and twenty-three postoffices had been put under the operation of the statute and said that he was persuaded that the effects of the act had "thus far proved beneficial." 2 The first report of the commission was submitted to Congress by the President in February, I884, with the statement that Congress and the people were to be congratulated on the good results which the law had already accomplished, and a recommendation that adequate appropriations be allowed to continue the work. The report further stated that about 14,000 employees had been classified according to the law and contained reports from the various places where the law was in effect that were almost unanimous in approval. It closed with the statement that the commission " in every stage of its work has had the constant and unwavering support of the President." 3 ..

The provisions of the law checked but did not entirely eradicate the attempts to make office-holders contribute to campaign funds. In the campaign of I 884 the Republican Congressional Committee evaded the spirit of the law by appointing a sub-committee of five who were not officeholders to act as a finance committee and receive contribu-

${ }^{1}$ Nation, March 8, 15, 1882.

2 Richardson, vol. viii, p. I87.

House Ex. Doc., 48 C., I S., no. I05. 
tions from government employees. ${ }^{1}$ Several state committees asked for contributions as usual. The Indiana Republican committee announced that a list of those who contributed and of those who did not would be sent to the national committee. ${ }^{2}$

The passage of the civil service reform law is an excellent example of a reform forced on politicians against their will by the pressure of public opinion aroused by a few earnest advocates. The politicians of neither party really wanted the reform, but few of them dared attack it openly. In the Republican national convention of I880 the committee on resolutions cut out the plank on civil service reform and it was put back by the convention only after a warm debate. In the course of the debate what many Republicans probably really thought of the reform was naively expressed by delegate Flanagan of Texas. "Texas," he said, "has had quite enough of civil service reform . . . We are not here for the purpose of providing offices for the Democrats. There is one plank in the Democratic party that I have ever admired and that is "To the victor belongs the spoils.' What are we up here for?" ${ }^{3}$ The Republican Congressional Committee, in the Republican campaign textbook for 1882, characterized George W. Curtis and the New York Civil Service Reform Association as "bogus reformers" and as a "combination of unprincipled yclept reformers." 4

What many Democrats really thought of the reform was expressed by some of their number in their speeches against the Pendleton bill. It also might be guessed from

${ }^{1}$ N. Y. Times, Aug I, Nation, Aug. 7, 1884 .

${ }^{3}$ N. Y. Times, Oct. 26; Nation, Oct. 30, 1884.

3 Proc. of the Conv., p. 168.

4P. II4. 
the fact that they, while attacking the Republicans for abuses, had made no attempt to force the issue in all their period of control of the House. In the next session of Congress, after the passage of the reform act, the House committee on civil service brought in a report unanimously favoring the abolition of the four-year limit for the tenure of federal officials. This was a logical extension of the idea of reform, but it was rejected by a vote of 146 to 99 , I2I of the 146 being Democrats. ${ }^{1}$ A bill for the repeal of the civil service act was introduced in the same Congress by a Kentucky Democrat but no action was taken on it. ${ }^{2}$ The attitude of Democrats toward the reform was further shown by the action of the Ohio legislature in refusing a re-election to Pendleton and electing in his place Oliver Payne, who, as one Ohio paper expressed it, had not had his head turned with the "buzzing of the Presidential bee, thereby un-Americanizing him into the originating, championing, and passage of a bastard British Civil Service class law". 3

The classic speech of the period, however, was made by Benjamin Butler in the Democratic convention of 1884 . Butler said:

You start off in your platform at one point and say that you are for an honest Civil Service reform. Now I will venture to say that there is not a man in this Convention that is in favor of Civil Service reform unless he is a schoolmaster. One of the first statesmen of Ohio, one who had a right to be brought here, brought by his Delegation and put before you for your suffrages as President, an able and learned man, got carried away by the doctrinaires and started once more a Civil Service reform. And it carried him so far out of sight

${ }^{1}$ McPherson, 1884, p. 187.

'Nation, Jan. 17, 1884.

${ }^{3} N$. Y. Tribune, Jan. 8; N. Y. Times, Jan. Io; Nation, Jan. 17, 1884. 
with the Ohio Democracy that he never has been heard of since. What is this Civil Service reform? It is to give the man the preference who shall appear to have the most learning. He signs a paper containing questions, and if he can answer the questions, he is said to be "selected." Now, what I want is that men from the people, honest and earnest men, men of purity and integrity, shall have the offices; and you cannot learn that by any schoolmaster examination.

Oh, what is this above my head? The portrait of George Washington! And he could not have passed examinations for a clerkship. Let me repeat. George Washington could not have passed a Civil Service examination in the capital named for him for a \$1200 clerkship. His early education had been neglected, and in his will, written by his own hand, he spells "clothes", c-1-o-a-t-h-e-s. Therefore I have said that the offices belong to the people. And there ought to be frequent change of officers, in order to look over the books and see who are defaulters. And they want to be all turned out, or else when you try to punish them they will all protect one another, as they did in the star route trial.

Again, I want frequent change of officers in order to counteract the great tendency of these times to a caste of aristocratic life officers. If an office is a good thing, then I want all the people to have a shot-have a chance at it. If it is a bad thing, it is too hard to put it onto a poor fellow for his whole life. ${ }^{1}$

The New York Sun in commenting on this speech said: " In these days of sentimentality and humbug it is delightful to find a fellow cool-headed enough and manly enough to declare the old-fashioned doctrine." 2

Both parties endorsed the reform in their platforms of I884. The Democrats rather casually included a statement that they favored "honest civil service reform and the

${ }^{1}$ Proc. of Dem. Conv., 1884, p. 209.

${ }^{3}$ July 24,1884 . 
compensation of all United States officers by fixed salaries" in the same paragraph in which they announced that they favored the separation of church and state and the diffusion of free education. The Republican statement was more definite and complete. It asserted that the reform, "auspiciously begun under Republican administration" should be extended to "all the grades of the service to which it is applicable," that the spirit and purpose of the reform should be observed in all appointments and that all laws at variance with it should be repealed. ${ }^{1}$

The friends of the reform realized that, in spite of platforms, the great majority of the politicians of both parties were hostile to it and that it was necessary, therefore, to elect a President who was really in sympathy with it. The Pendleton law was not mandatory upon the President, and although it was hardly probable that any President would be bold enough to disregard the law entirely, he could make it practically a dead letter by not extending it to other services or by appointing a commission not actively interested in it and not likely to enforce it faithfully. The attitude of the nominees was, then, all-important. No matter how strongly either party might endorse the reform in its platform, unless the candidate was believed to be sincerely in favor of it, the reformers would not support him.

Blaine, as chairman of the Maine Republican committee and as a leader of his party in Congress, had been for years in a position where he might have done a great deal for the reform. Neither by word nor by deed, however, had he done anything to promote it and, in fact, his influence had been against it. As Speaker of the House in the forty-third Congress he had prevented the idea from getting any consideration by the appointment of a committee on the reform, of which Benjamin Butler was the most prominent

${ }^{1}$ Stanwood, Presidency, pp. 430, 437. 
member, ${ }^{1}$ which in the language of the New York Tribune, "strangled the reform, and scalped it, and then executed a war dance over it." 2 A series of articles by Gail Hamilton appeared in the New York Tribune from April to August, 1877, ridiculing the reform in general and the attempts of the Hayes administration at reform in particular; and these articles were supposed, because of the author's close relations with the Blaine family, to reflect Blaine's views on the subject. ${ }^{3}$ In the campaign it was pretty well proven that these articles were inspired by Blaine himself." According to his opponents, Blaine, while Secretary of State "wallowed in spoils." " His declarations in favor of the reform in the campaign of 1882 and his subsequent assertions of his devotion to the principle were looked upon as the "traditional tribute paid to virtue." "

(Perhaps it was Cleveland's good fortune that he came into prominence when the reform was already popular. At any rate his record was a contrast to that of Blaine. Throughout his public career he had consistently favored the reform and worked for it. In his letter accepting the nomination for governor he gave it a prominent place, and in reply to a letter of the civil service reform association he declared that he fully approved the principles embodied in the Pendleton bill. ${ }^{7}$ In his message to his first legislature he strongly urged the enactment of a law to establish the

${ }^{1}$ House Journal, 43 C., I S., p. 65; Harper's Weekly, Oct. 25, I884; Fish, op. cit., p. 217.

${ }^{2}$ June 19, 1874

Eaton, Indep. Movement, p. 162.

4 Report of Ex. Com. of Independents, p. I5.

${ }^{5}$ Nation, Sept. 14, 1882.

- N. Y. Times, July $2 \mathrm{I}, \mathrm{I} 884$.

'Parker, Writings of Grover Cleveland, p. 38. 
merit system in appointments, ${ }^{1}$ and when the legislature $\downarrow$ enacted such a law, he appointed a commission actively interested in its success. ${ }^{2}$

Although the Republican party probably contained a larger proportion of men interested in civil service reform than the Democratic, and although their platform declaration was more definite and outspoken, it seemed to the Independents that the Democrats with Cleveland as President offered more promise of a continuance and extension of the reform than did the Republicans with Blaine. The desire to promote reform of the civil service was one of the main reasons for the "Mugwump" revolt, and must therefore be given a prominent place among the real issues ? of the election.)

${ }^{1}$ Public Papers of Grover Cleveland, 1883, p. 25.

${ }^{2}$ Nation, May 5, 1883. 


\section{CHAPTER VI}

The Issues in I884-The Tariff

The tariff has been widely discussed in practically every Presidential campaign since the Civil War. In some of them it has been a real issue, but more often it has been brought forward as a device for distracting attention from other issues which politicians have not wished to have discussed. The tariff has lent itself to this sort of handling for various reasons. The whole question of a protective tariff involves many complicated technical details which the average citizen has neither the time nor the inclination to master. The effects of a tariff are hard to isolate. The manufacturer with capital invested in a protected industry has a selfish reason for desiring protection and has not shown himself to be overscrupulcus in the methods used to get it. The voter employed in a protected industry, being anxious to safeguard his own interests and not being a trained economist, is likely to accept at their face value arguments advanced for protection, especially when they emanate from his employer. For example, a comparison of wages in protectionist United States with those of freetrade England is often accepted without stopping to compare wages in protectionist Germany and free-trade England. Tariff discussion played an important part in the campaign of I884. A brief survey of the history of the tariff since the war will be useful in determining whether or not it was a real issue in that campaign.

One of the most pressing problems before Congress at 106 
the close of the war was a general reorganization of finances. During the war the exigencies of the treasury had compelled recourse to every known means of raising revenue. Manufacturers were compelled to pay a tax on their raw material and on the finished product, a license tax for doing business and an income tax on their profits. At the same time, because it was desired to stimulate manufactures, tariff duties were raised to counteract the effect of these internal taxes. In the bustle of war-time when little discrimination could be made as to what were proper rates of duty, the manufacturers received practically any rate that they asked. ${ }^{1}$ These war tariffs were avowedly temporary, ${ }^{2}$ but when the time came for reducing taxes, although the internal taxes were taken off, the tariff remained practically the same. The average citizen was too much distracted by the spectacular features of reconstruction to pay much attention to complicated questions of finance. The manufacturers, however, were interested in the tariff, even if the public was not, and were able to resist any attempt to reduce the rates. The producers of raw materials were brought into line by increased duties on their products, and efforts fairly successful were made to convince labor that protection was in its interest. In time these high rates, which were to have been temporary, came to be looked upon as the results of a definite economic policy and their maintenance became the main aim of a large group of influential citizens. ${ }^{3}$

The tariff was always more of a sectional than a party issue. Sections in which manufacturing interests predominated were usually for protection whether they elected $\mathrm{Re}$ publican or Democratic Congressmen, while those sections

${ }^{1}$ Stanwood, American Tariff Controversies, vol. ii, p. I29.

${ }^{2}$ Ibid., p. I27.

${ }^{3}$ Taussig, Tariff History of the U. S., p. I7I. 
in which the main interest was agriculture or shipping were usually either only moderately for protection or against it entirely. ${ }^{1}$ So we see in the Democratic party a growing element that favored protection and in the Republican a considerable group of moderate protectionists and even a few free-traders. As has been mentioned, ${ }^{2}$ these " tariff reformers" in the Republican party played a considerable part in the Liberal movement of 1872.

The reductions in the tariff bill of that year were an attempt to allay the growing dissatisfaction with the attitude of the administration toward the tariff. ${ }^{3}$ This bill, beside repealing the duties on tea and coffee and making a few additions to the free list, provided for a horizontal reduction of ten percent on all rates. ${ }^{4}$ This reduction was short-lived. The falling off of the foreign trade, due to the panic of 1873 , together with the reduction in duties, caused the income from import duties to fall from $\$ 216,000,000$ in 1872 to $\$ 163,000,000$ in $1874,{ }^{5}$ a fact which gave an excellent excuse to the protectionists to countermand the ten percent reduction and also to add twenty-five percent to the duties on molasses and sugar. Although this bill was nominally for the purpose of safeguarding the treasury, the protectionists uniformly supported and the revenue reformers opposed it. ${ }^{6}$ The bill became a law on March 3, 1875, the day before the Republicans went out of power in the house for the first time in fourteen years.

For the next six years neither party had control of both houses of Congress and the Presidency at the same time.

1 Cf. supra, p. 23.

${ }^{2}$ Vide supra, p. 28.

3 Stanwood, Tariff, p. I77.

' Dewey, Financial History, p. 398.

${ }^{5}$ U. S. Stat. Abst., 1885, p. 2.

-Stanwood, Tariff, p. 189. 
During this period no tariff legislation of importance was passed, although there was a great deal of discussion. It was a situation dear to the hearts of politicians, where they might promise great things without any danger of being held responsible for not making good their promises. Although the tariff was not made much of in the campaign of $1876,{ }^{1}$ it occupied a prominent place in the platforms of both parties. The Republicans declared that the revenue should be "largely drawn" from duties on imports "so adjusted as to promote the interests of American labor and advance the prosperity of the whole country." The Democrats denounced the existing tariff in a long paragraph that began by calling it "a masterpiece of injustice, inequality, and false pretence," and closed with a demand that "all custom-house taxation shall be only for revenue." ${ }^{2}$ In spite of this unequivocal declaration a resolution introduced into the House December I, 1877 , to instruct the committee on ways and means " to so revise the tariff as to make it purely and solely a tariff for revenue, and not for protecting one class of citizens by plundering another," failed through lack of Democratic support. ${ }^{3}$ A bill introduced by the committee of which Fernando Wood of New York was chairman, providing for a reduction of rates on manufactures, failed for the same reason. Of the $\mathrm{I} 34$ votes against the bill, nineteen were Democratic, thirteen of them being from Pennsylvania and New Jersey; of the I2O votes for the bill, seven were Republican, two from " unredeemed" southern states and five from the Middle West. Twentytwo Democrats did not vote. ${ }^{4}$

In I880 the tariff, quite unexpectedly, played a prominent

'Haworth, Disputed Election of 1876 , chap. iv.

${ }^{2}$ Stanwood, Presidency, pp. 37I, 376.

${ }^{3}$ Cong. Rec., 45 C., I S., p. 8II; McPherson, I878, p. 201.

'Cong. Rec., 45 C., I S., p. 4I54; McPherson, I878, p. 202. 
part in the campaign. In their platform the Republicans briefly affirmed " the belief avowed in 1876 , that the duties levied for the purpose of revenue should so discriminate as to favor American labor." The Democrats in a brief platform merely mentioned "a tariff for revenue only" as one of the doctrines and traditions of the party, the same doctrine, be it noted, though not so strongly worded, as that contained in the platform of 1876 , to which no particular attention was paid in the campaign by their opponents, or in Congress by themselves. ${ }^{1}$ As a matter of fact, " tariff for revenue only" was merely a phrase. The Democrats, even if they had wished to, could not have united the party in support of such a policy. ${ }^{2}$ The Republicans, however, in their search for an issue in a campaign practically devoid of issues, seized upon these words as of gigantic import and spent the closing weeks of the campaign in picturing the woes that would follow an attempt to reverse "the traditional policy of the country." General Hancock's naive remarks on the subject did not strengthen the position of his party. ${ }^{3}$

The Republicans might have accepted the vote of the country as a vindication of the existing tariff and have felt under no compulsion to change had not the question of protection become complicated with the broader one of revenue. With the general revival of business that began in 1879 the income from both internal and tariff taxes increased enormously. Customs receipts grew from $\$ 130$,000,000 in 1878 to $\$ 220,000,000$ in 1882 and internal revenue receipts from $\$ 110,000,000$ to $\$ 146,000,000$ in the same period. This resulted in a surplus of receipts over

${ }^{1}$ Stanwood, Presidency, pp. 405, 4I3.

${ }^{2}$ Cf. Nation, Oct. 21, 1880.

3 Stanwood, Tariff, p. I90; vide also N. Y. Times, Tribune and Nation, Oct. and Nov., 1880. 
expenditures of $\$ 65,000,000$ in $1880, \$ 100,000,000$ in 1881 and $\$ 145,000,000$ in 1882 , with an unexpended balance for the same years respectively of $\$ 386,000,000, \$ 231,000,000$ and $\$ 280,000,000 .^{1}$

A governmental surplus is never a thing to be desired, as it encourages extravagance and withdraws money from circulation. From a purely political point of view also it is undesirable, as the argument that more taxes than are necessary are being taken from the people. is likely to be a disastrous one for the party in power. What should be done, then, with these huge balances? Pay off the national debt, some said. True, the debt in I 882 amounted to nearly two billions, but the larger part of this amount would not come due until I89I and 1907. Experience had shown that an attempt to cancel this long-time debt by buying bonds in the open market would raise their price so high that it would be poor policy to purchase them. There was, besides, some doubt as to whether the Secretary of the Treasury had the legal power to purchase bonds at a premium. \$414,000,000 of the debt was due and payable at the time, but the Secretary did not consider it wise to pay all this off, as there would then be no outlet for the surplus in case of a sudden financial stringency in which the country needed currency. At the best, such action would afford but temporary relief. ${ }^{2}$ As to reduction of internal taxes, those taxes still in force were mainly on liquors and tobaccos and their retention was urged for moral reasons.

The protectionists were therefore faced by the problem of either reducing the tariff or finding new ways of spending money. One of the most obvious methods of getting rid of the surplus was to increase the expenditure for pensions. This method offered an almost unlimited field for

${ }^{1} U$. S. Stat. Abst., 1885, pp. I and 2.

${ }^{2}$ Report of Sec. of Treas., 1882 , pp. xxv-xxvii. 
expenditure and at the same time an opportunity to a Congressman to make himself popular by securing appropriations for an ostensibly worthy and patriotic purpose. Appropriations for pensions had decreased between 1874 and 1879, but the arrears act of 1879 caused large increases, not only by payment of arrears but also by stimulating new claims. In 1879 appropriations amounted to but $\$ 29,000,-$ 000 ; in 1883 they were $\$ 116,000,000 .^{1}$ Another form of extravagance, which grew into an abuse then and which still exists, was in the appropriations for rivers and harbors. This expenditure, also useful in strengthening a Congressman in his home district, increased from a negligible amount before the war to $\$ 8,000,000$ in 1879 and $\$ 18,000,000$ in 1883 , the later bill being passed over the veto of President Arthur.

The surplus and the resulting extravagance of Congress played an important part in the political overturn of $1882 .^{2}$ When the new Congress assembled a Democratic House shared the responsibility for expenditures, and appropriations for 1884 showed a decrease of $\$ 21,000,000$. The Republican Senate was still busy with plans for spending money. Many schemes were advocated and some actually passed which would have extended the pension system to ridiculous limits. ${ }^{3}$ Another plan, which gained the support of many on account of its real merit but whose main purpose was to use up the surplus, was the Blair bill, passed by the Senate in 1884 , which provided for the distribution of $\$ 77,000,000$ among the states in aid of education. ${ }^{4}$

${ }^{1}$ U. S. Stat. Abst., 1885, p. 4; Glasson, Hist. of Military Pension Legislation, p. 90.

${ }^{2}$ Vide supra, p. 65.

${ }^{3}$ McPherson, I884, p. 169; N. Y. Times, March 24, 25, I884.

'Sen. Rep., 48 C., I S., no. Ior; McPherson, 1884, p. I47; Nation, March 10, 1884 . 
The moderate protectionists had realized all along that, in spite of the attempts to reduce the surplus, eventually the tariff must be reduced. In his message of $188 \mathrm{I}$ President Arthur declared that the time had arrived when the people might " justly demand some relief from their present onerous burden of taxation." $\mathrm{He}$ recommended the abolition of all internal revenue taxes except those on tobaccos and liquors, but added that the tariff also needed revision, and suggested a commission to aid Congress in this work. ${ }^{1}$ A tariff commission had been suggested several times in Congress by both Republicans and Democrats, ${ }^{2}$ but when it was proposed in 1882 , it was attacked by the Democrats as being merely a protectionist ruse to delay revision. ${ }^{3}$ It passed the House with but thirty Democratic votes and the Senate with only six. ${ }^{4}$ The bill provided for the appointment of nine commissioners from civil life who were to conduct an investigation of all industries affected by the tariff with a view to a revision "that would be just to all interests." All of the members appointed were favorable to protection and four of them were directly connected with protected industries. The chairman was John L. Hayes of Massachusetts, secretary of the National Association of Wool Manufacturers. ${ }^{5}$

The commission traveled over the country taking testimony for three months. Its itinerary included Boston, New York, St. Paul, Des Moines, St. Louis, Savannah, Pittsburgh and Philadelphia. Anybody who chose was allowed to appear before the commission and state his views, which

${ }^{1}$ Richardson, vol. viii, p. 49.

${ }^{2}$ Cong. Rec., 45 C., 2 S., pp. 3252, 4155; 46 C., 2 S., pp. 4102-4116.

${ }^{3}$ Ibid., 47 C., I S., p. 3668.

${ }^{4}$ McPherson, I882, p. I10; Stanwood, Tariff, p. 203.

${ }^{5}$ Report of Tariff Com., House Misc. Doc., 47 C., 2 S., no. 6; Stanwood, p. 204. 
were fully embodied in the report. Only public officials were summoned to appear. Naturally of the 604 witnesses examined the majority were representatives of protected interests, although there was a liberal sprinkling of freetraders. It was noticeable that the representatives of each industry were willing to subscribe to the doctrine of tariff reform as a general proposition but were sure that a reduction in their own particular industry would be disastrous. The commission declared that the aim of its members was " to divest themselves of political bias, sectional prejudice. or consideration of personal interest" and to "serve no particular party, class, section, or school of political economy." Without doubt they accomplished this so far as they were consciously able. Considering the economic background of the members, their report was a surprise. ${ }^{1}$ They reported that,

early in its deliberations the Committee became convinced that a substantial reduction of tariff duties is demanded, not by a mere indiscriminate popular clamor, but by the best conservative opinion of the country . . . such a reduction of the existing tariff the Committee regards not only as a due recognition of public sentiment and a measure of justice to consumers, but one conducive to the general industrial prosperity. . . . No rates of defensive duties, except for the establishment of new industries, which more than equalize the conditions of labor and capital with those of foreign competitors, can be justified.

Some tariff reformers, however, were disappointed when they came to the details recommended, insisting that the commission had failed to put their conclusions into practice. $^{2}$ The reductions recommended, the commission esti-

${ }^{1}$ H. C. Baird, The Tariff of the Tariff Com.

Nation, Feb. 6, 1883 . 
mated, would average from twenty to twenty-five percent. ${ }^{1}$

The bare fact of the creation of the commission, to say nothing of its report, is important as marking a distinct recognition by the Republican party that the scheme of high protective duties had been carried too far and continued too long. Some industries felt that they had outgrown protection and were ready to compete for the world market. ${ }^{2}$ The attitude of others was well expressed by Mr. Hayes, the chairman of the commission, in the Wool Manufacturers' Bulletin:

Reduction in itself was by no means desirable to us; it was a concession to public sentiment, a bending of the top and branches to the wind of public opinion to save the trunk of the protective system. In a word, the object was protection. through reduction. We were willing to concede only to save the essentials both of the wool and woolens tariff. . . . We wanted the tariff to be made by our friends. ${ }^{3}$

Secretary Folger, in his report for 1882 , recommended " a careful revision of the tariff, with a view to substantial reductions." " President Arthur in his annual message commended the report of the Commission and declared that the best interests of the country demanded large reductions in the tariff. He specifically urged an enlarged free list with "the simplification of the complex and inconsistent schedule of duties upon certain manufactures, particularly those of cotton, iron and steel, and a substantial reduction of duties upon those articles, and upon sugar, molasses, silk, wool and woolen goods." $\mathrm{He}$ expressed the hope that if a general revision was impossible, "at least some of the more conspicuous inequalities of the present law" might

Report, p. 6. ${ }^{2} N . Y$. Times, Jan. I, I884.

${ }^{3}$ Quoted in Taussig, Tariff Hist., p. 249.

'House Misc. Doc., 47 C., 2 S., p. xxxii. 
be remedied. ${ }^{1}$ The report was taken up in both houses and bills introduced. The Senate, to avoid the constitutional restriction against the origination of the revenue bills in that body, tacked their bill on to a bill to reduce the internal taxes that had passed the House at the previous session. The Senate bill provided for rates considerably lower than those of the House bill but higher than those recommended by the Commission. The House had a large protectionist majority, but the reformers were obstructive and were able to prevent the passage of the House bill. By a bit of parliamentary legerdemain the Republican leaders secured a disagreement to the Senate bill and a reference of the bill to a conference committee made up of strong protectionists. ${ }^{2}$ The conference committee "compromised" by raising the rates higher than those of either house ${ }^{3}$ and the report was forced through on the next to the last day of the session. The tariff had indeed been revised by its friends.

The conference committee had so mutilated the Senate bill that it barely passed the Senate by a vote of thirty-two to thirty-one. Only one Democrat, McPherson of New Jersey, voted for it, while the original bill had received ten Democratic votes. In the House the bill passed by a vote of $\mathrm{r}_{52}$ to I 16 . Sixteen eastern Democrats, led by Randall of Pennsylvania, were included in the majority, while twelve Republicans, ten of whom came from Pennsylvania and Ohio, voted against the bill. The Republicans who voted against the bill did so for the most part because the rates were not high enough, especially those on raw wool. The bill made reductions on most articles but raised the rates on certain classes of woolen and cotton goods and

'Richardson, vol. viii, p. I35.

'Stanwood, op. cit., p. 2 I I et seq.

${ }^{*}$ Cong. Rec., 47 C., 2 S., p. 3724 , appendix, p. 278. 
manufactures of steel. The increases were put in most cases on classes of goods of which there were large importations. Some increases were made to appear as decreases by changes in classification. The bill contained many discrepancies and as a whole was satisfactory to no large faction of either party. Besides the changes in the tariff, substantial reductions in the internal revenue were made by the abolition of the taxes on friction matches and patent medicines, the removal of various banking taxes and a reduction of the rates on tobaccos. ${ }^{1}$

The election of I882 which changed a Republican majority of thirteen in the House to a Democratic one of seventy$\operatorname{six}^{2}$ was the result as much of disgust with the Republicans as of any real promise that the Democrats held forth. No partisan legislation could be expected, as the Senate remained Republican, but the country looked to the Democratic House to see whether the Democrats would have a real program to offer in I884 or would offer Democratic inefficiency and selfish local bickerings as an alternative to those of the Republicans. It was obvious from their votes in the previous Congress that the party was not a unit on the question of the tariff. The newspapers that leaned toward free trade or tariff reform declared that the great opportunity for the Democrats lay in making reform of the tariff the issue in I884, and showing their sincerity by passing a bill for equalization and reduction at the present session and putting the responsibility for killing it squarely up to the Republican Senate. ${ }^{3}$ The Republican papers and the

${ }^{1}$ Dewey, Fin. Hist., p. 419; Noyes, Forty Years of Am. Fin., p. 92; McPherson, 1884, pp. I8-71; Sherman, Autobiog., vol. ii, p. 851 ; McKinley, The Tariff, p. 64; Cong. Rec., 47 C., 2 S., p. 3742.

${ }^{2}$ McPherson, I884, pp. I, I29. The majorities mentioned are those over all other parties combined.

${ }^{3} N$. Y. Times, May 7, 1884; Nation, March 27, 1884; Lowisville Courier-Journal, March 17 , 1884, quoted in the $N$. Y. Tribune of April I8. 
protectionist papers of the Democrats urged that the Democrats must maintain harmony within the party at all costs, and that harmony could be maintained only by leaving the tariff question severely alone. ${ }^{1}$

The tariff was the main issue involved in the contest over the speakership at the organization of the House in December, I883. The candidate of the "no agitation on the tariff" group was Randall of Pennsylvania, who favored reducing the surplus by abolishing the tax on liquor and tobacco. The tariff-reform, or as the Republicans insisted, the free-trade candidate was Carlisle of Kentucky, who favored unrestricted discussion of the tariff question with the ultimate object of reducing duties and preparing the way for free trade and who was opposed to abolishing the internal taxes. ${ }^{2}$ Carlisle was elected, and agreeably disappointed the protectionists by his moderate speech on taking the chair. He declared that "sudden and radical changes in the laws and regulations affecting the commercial and industrial interests of the people .. . would not be favorably received by any considerable number of those who have given serious attention to the subject." ${ }^{3}$

The Secretary of the Treasury in his report for 1883 stated that the income for the first three months under the new revenue law indicated that the annual reduction in revenue from internal taxes would be $\$ 10,000,000$ less than estimated by the Senate committee, and the reduction in the tariff $\$ 20,000,000$ less. He thought that it might be too soon to reduce the tariff again but that "ultimately the just and expedient method of relief from taxation, and of limiting the revenues to the needs of an economical govern-

${ }^{1} N$. Y. World, Dec. 13, I883, March 3, May 7, I884; N. Y. Tribune, May $7,8,1884$.

'Nation, Nov. 22, I883.

${ }^{3}$ Cong. Rec., 48 C., I S., p. 5. 
ment must be found in a reduction in the duties on imports." 1 President Arthur in his annual message declared that he had "no doubt that further reductions may be wisely made," but urged that no " radical revision or sweeping reduction" be made until the results of the act passed by the last Congress were more apparent."

Morrison of Illinois was made chairman of the ways and means committee, which was equally divided between high and low tariff men, with Abraham S. Hewitt of New York, a revenue reformer and at the same time an iron manufacturer with large interests, holding the balance of power. This committee reported a bill which provided for a twenty percent horizontal reduction with a maximum rate of forty percent on cotton goods, sixty percent on woolens and fifty percent on metals. No rate was to be lower than that levied by the Morrill act of I86r. Salt, coal and lumber were added to the free list. The estimated reduction in the revenue was $\$ 30,000,000$. The committee pointed out that the proposed reductions, together with those of the bill of I 883 , did not equal the reductions proposed by the tariff commission. They also laid the blame for the existing industrial depression, especially that in the iron trades, at the door of the protective system, declaring that such depressions were inseparable from the enormities of that system. The line which the Republican opposition was to take was disclosed in the minority report, which asserted that it was too soon to know the effects of the bill of the previous session, that no one had asked for a change, that only freetraders favored a change which was to be an entering wedge, that the reported bill would disturb business, lower wages, increase revenues by increasing foreign imports and that the bill was unscientific and poorly drawn. ${ }^{3}$

${ }^{1}$ House Ex. Doc., 48 C., I S., no. 2.

${ }^{2}$ Richardson, vol. viii, p. I79.

${ }^{3}$ House Report, 48 C., I S., no. 792. 
At a caucus of the House Democrats, held March 25, it was voted, I I 4 to 57 , that the Morrison bill be taken up as soon as possible and passed, but with the proviso that the action of the caucus should be binding on individuals only to the extent " that each member may feel that he ought to be influenced by the expressed opinion of the majority of his associates." A resolution introduced by Carlisle also passed which provided for the abolition of all taxes on tobacco, snuff and cigars and a reduction of the tax on brandy distilled from fruits to ten cents per gallon, " provided that such repeal and reduction shall not be made except in connection with a reduction of tariff duties." 1 Converse, a Democrat from Ohio, on April 7 , moved to suspend the rules and restore the duties of the bill of 1867 on wool. The Democrats refused to stultify themselves by accepting this chance to gain the support of the Ohio Democrats for the tariff bill, and the motion was lost I I9 to I26, although 39 Democrats voted with the Republicans to restore the rates. ${ }^{2}$ On April I 5 the Morrison bill was taken up in committee of the whole and occupied most of the time of the House until May 6, when the enacting clause was struck out on the motion of Converse. Randall made the principal speech against the bill. ${ }^{3}$ Of the I59 votes against the bill, forty-one were Democratic, the New England states furnishing one, the Middle Atlantic twentythree, the South two, the West eleven and the Pacific four. Pennsylvania alone furnished twelve Democratic votes against the bill and Ohio ten. Four Republicans, all from Minnesota, voted with the I 5 I Democrats who favored the bill. ${ }^{4}$ On May 12 a new tariff bill was introduced by $\mathrm{A}$. S.

${ }^{1}$ Nation, March 27, $188_{3}$.

${ }^{2} \mathrm{McPherson,}$ 1884, p. I37.

${ }^{3}$ Cong. Rec., 48 C., I S., pp. 3872-3908.

${ }^{4}$ McPherson, pp. I35-137; $N$. Y. Times, May 7, 1884. 
Hewitt of New York, which provided for an enlarged free list and reductions averaging from ten to twenty percent. This bill was less objectionable to the protectionists than the Morrison bill and met the valid objection to a horizontal reduction. It was reported favorably by the ways and means committee but the adjournment of Congress on July 7 prevented any action. ${ }^{1}$

So for better or worse ended the Democratic attempts at tariff revision. Instead of seizing the opportunity to take a much-needed step toward reducing the burden of unnecessary taxation and wiping out the surplus, the necessity for which the Republicans had on various occasions admitted, the Democrats forced upon their party a share of the responsibility for the existing duties. Randall and his cohort had really done a great service for the Republicans by forcing the Democrats to drop one of their strongest issues. When the Republicans unexpectedly attempted to make the tariff one of the main issues of the Presidential campaign of 1884 , the Democrats found themselves on the defensive, giving arguments to show that they were not hostile to protection.

A circumstance that not only influenced tariff discussion in the campaign but also undoubtedly had a broader bearing on its outcome was the general business depression that had existed in the country for over two years. The recovery from the panic of 1873 was slow, but the reaction was at its height in 1880 and helped materially in the Republican victory. The boom times continued through $\mathrm{I} 88 \mathrm{I}$ and into I882, when the effects of the crop failure of the previous year, and the inevitable consequence of overproduction and overextension of credit, both in the United States and abroad, began to be felt. ${ }^{2}$ Among the first to be affected

${ }^{1}$ House Reports, 48 C., I S., no. 197 I.

${ }^{2}$ Cf. supra, p. 65 . 
was the railroad industry, which had been extended far beyond what conditions warranted. From I879 through 1882 the annual increase in agricultural acreage had been two percent, and in population two percent, but the annual increase in railroad mileage had been nine percent. ${ }^{1}$ In 1882 there were II,596 miles of railroad constructed; in 1883 but $6,753 .^{2}$ This check in the railroad industry was immediately felt in other lines, particularly in those dependent upon railroad construction. There was a continuous decline in the value of securities. A general liquidation, starting in railroad stocks and others dependent on them and spreading to those of all other industries, began in the fall of 1882 and continued throughout the next two years. Although there was no crisis so severe as that of I 857 or 1873 , it was a period of continually declining prices, reduction of wages and general stagnation of industry. ${ }^{3}$

The financial crisis came in May, I884, with the failure of several prominent New York banks and brokerage houses. Clearing-house certificates were resorted to. For a few days the panic threatened to reach the dimensions of that of 1873 , but thanks to the long period of liquidation, its effects were confined largely to New York city and it was mainly a "stock-brokers' panic." Many of the failures were attributable to dishonest speculations and embezzlements by officials of the firms concerned. ${ }^{4}$ The Republicans were quick to lay the blame for the whole affair on the Democratic attempt to lower the tariff, in spite of the

${ }^{1}$ Railroad Gazette, Sept. 21, 1883; Nation, Sept. 27, 1883.

'U. S. Stat. Abst., 1885, p. 195; N. Y. Times, Jan. 4, 1884.

${ }^{3}$ Noyes, op. cit., p. 85; Ann. Cyc., 1883, p. 332; Commercial and Financial Chronicle, Jan. 5, I884, Jan. 3, I885; Nation, Jan. Io, r884.

${ }^{4}$ N. Y. Times, May 15, 17; Nation, May 8, 15, 22; Bradstrect's, May 22, 3I, 1884 . 
fact that the Morrison bill had been killed a week before the main crisis occurred. ${ }^{1}$

Although the market soon rallied, industry did not recover for some time. An idea of the extent of the business depression may be had from an examination of some of the indices of business prosperity. Business failures increased from $4,35^{\circ}$ in 1880 to 10,299 in 1883 and II,620 in I 884 , while the total liabilities of the failures of the respective years were $\$ 57,000,000$, \$175,000,000, and $\$ 248,000,000 . "$ The total exchanges at the New York clearing house fell from $\$ 48,000,000,000$ in 188 I to $\$ 40,000,000,000$ in 1883 and $\$ 34,000,000,000$ in $1884 . .^{3}$ The value of all imports was $\$ 667,000,000$ in 1880 , rising to $\$ 724,000,000$ in 1882 and falling back to the figure of 1880 in 1884 , in spite of the supposed encouragement of imports by the reduced tariff. The value of exports fell from $\$ 835,000,000$ in I 880 to $\$ 740,000,000$ in $1884 .{ }^{4}$ There was a noticeable falling off in the amount of practically all manufactures, notably of thirty percent in the production of steel and iron rails and of tiventy-five percent in the production of crude petroleum, comparing the calendar years 1882 and I884. ${ }^{5}$ Due partly to the disorder in the financial markets but probably more to the increased production, both foreign and domestic, grain prices fell to a new low level. A1though there was an increase in the total cereal production of the United States from 2718 million bushels in the bumper year I880 to 2992 in I884, and an increase in the acreage from 120 millions to 136 , the total value of the

${ }^{1} N$. Y. Tribune, May 19.

${ }^{2}$ Bradstreet's, Jan. 3, I 885 .

${ }^{3}$ U. S. Stat. Abst., I885, p. 25, for years ending Oct. I.

"Ibid., p. 34. Figures for years ending June I. For statistics given in terms of money value, allowance should be made for declining prices.

${ }^{5}$ Ibid., I886, pp. 142, I44. 
crops for the same years fell from $\$ I, 361,000,000$ to $\$ I$,I 84,000,000. ${ }^{1}$

In I880 the Republicans had based their tariff arguments on the existing prosperity, claiming for the protective policy the credit for the existing conditions. Now, in I884, although few changes had been made in the tariff, and those few by the Republicans themselves, the country was suffering from a severe and far-reaching industrial and financial depression. Logically; it would seem that under the circumstances the Republicans would find it difficult to urge a continuance of the protective system, but political exigencies are superior to all logic. The hard times and the resulting decrease in revenue also robbed the Democrats of an issue. The income from customs fell from $\$ 220,000,000$ for the year ending June 30,1882 , to $\$ 214,000,000$ for $188_{3}$ and $\$ 195,000,000$ in $I 884$. The income from internal revenue was for the same years respectively $\$ 146,000,000$, $\$ 144,000,000$ and $\$ 121,000,000$. The report for the three months ending September 30, I884, showed a decrease of $\$ 4,000,000$ from the corresponding three months of the previous year. ${ }^{2}$ Under these circumstances the surplus, while still large, did not appear so alarming to the popular mind.

In the campaign for the Presidential nominations the tariff played but a minor part. Arthur, in showing himself to be favorable to tariff reform, had incurred the enmity of the ardent protectionists. The Tribune charged him with being too much in sympathy with a group of New York importers who were really free-traders. ${ }^{3}$ Blaine's record on protection was satisfactory and he was entirely acceptable to the most radical protectionists. In November, I883, he

1 U. S. Stat. Abst., 1885, p. 200.

2 Ibid., p. 2 ; Report of Sec. of Treas., 1885, p. v.

'May I2, 31, I884. 
wrote a letter to the editor of the Philadelphia Press in which he outlined an ingenious scheme for getting rid of the surplus and at the same time increasing the tariff duties, namely, that the existing excise taxes should be continued and that all income from them be turned over to the states according to population. He submitted figures to show that this plan would do away with the necessity for state taxes in all but three of the states and county taxes in about half of them. The Tribune hailed the proposal, in an editorial headed "Free Homes or Free Whiskey," as being the most statesmanlike suggestion of a generation. ${ }^{1}$ Various forms of this plan had been advocated by high protectionists before, notably by the Pennsylvania State Republican Convention of 1883 , but it was never seriously considered. ${ }^{2}$

Many of the state conventions ignored the tariff altogether, others adopted colorless resolutions. The Republicans, where they took any stand at all, demanded protection. It was noticeable that the outspoken declarations by the Democrats for tariff for revenue only came from those states that were solidly Democratic, while most of the doubtful states avoided the subject. ${ }^{3}$ In Illinois a faction led by Morrison secured the adoption of a platform demanding that all custom-house taxation be for revenue only and instructing the delegates to the national convention to vote for such a plank. Later, however, the protectionist element secured a reversal of this vote and the delegates were sent uninstructed. ${ }^{4}$ The Ohio Democratic convention adopted a platform that any Republican might endorse. ${ }^{5}$ The Pennsylvania Democrats, the leaders of the protectionist faction

${ }^{1}$ N. Y. Tribune, Nov. 29, 30, 1883.

${ }^{2}$ Nation, July 7,1883 .

${ }^{3} N$. Y. World, June 19, 26; Bradstreet's, June 28.

'N. Y. World, July 3.

${ }^{5}$ Ibid., June 26. 
in the party, adopted a platform which favored a tariff for revenue but "so adjusted as to prevent unequal burdens, encourage productive industries at -home, and afford just compensation to labor." They placed Randall in nomina. tion for the Presidency. ${ }^{1}$

The action of the Democratic House having made it clear that the party could not unite on a tariff policy, the nomination of a man prominently identified with either faction was plainly inexpedient. The protectionists were not strong enough to overthrow the traditions of the party and nominate so pronounced a protectionist as Randall, but they were able to make the nomination of anyone who had a definite leaning toward free trade, such as Carlisle or Morrison, out of the question. Part of the opposition to Bayard was due to his supposedly friendly attitude toward free trade. ${ }^{2}$ The assertion of the Republican press that the Democrats did not dare to take a stand on the tariff and that Cleveland was chosen because his attitude on the ques. tion was unknown, undoubtedly was largely true. ${ }^{3}$

The Democratic convention, after considerable wrangling in the committee on resolutions and on the floor of the convention, adopted a tariff plank which was plainly an attempt to please everyone and to avoid an issue rather than to make one. After the nomination of Cleveland, a Texas delegate introduced a resolution endorsing the Morrison bill and declaring that opposition to it on the part of Democrats was due to considerations of policy rather than of principle. The resolution was declared out of order by the chairman and sent to the committee on resolutions. ${ }^{4}$ The platform started out boldly by condemning the Republicans

${ }^{1} N . Y$. Times, April ro.

${ }^{2}$ N. Y. World, June 14, 24, 1884.

${ }^{3}$ N. Y. Tribune, June $12,13,17,1884$.

${ }^{4}$ Proc. of Dem. Conv., 1884, p. 252. 
for having created and continued the irregularities of the tariff, and for falsely pretending to protect American interests while taxing raw materials. It declared that the Republican policy had impoverished many industries to subsidize a few, that " unnecessary taxation is unjust taxation," and that the existing surplus was sufficient evidence of Republican injustice and incompetence. While denouncing the existing tariff and demanding that "federal taxation shall be exclusively for public purposes and shall not exceed the needs of the government economically administered," they admitted a large part of the protectionist contention by pledging themselves to revise the tariff "in a spirit of fairness to all interests," in a way that would not "injure any domestic industries" or "deprive American labor of the ability to compete successfully with foreign labor," and in a way which should be "regardful" of the labor and capital involved in the "many industries [that] have come to rely upon legislation for successful continuance." The nearest that the platform approached a definite program was in the statement that there should be "taxes on fewer imported articles, bearing heaviest on articles of luxury, and bearing lightest on articles of necessity." 1

The Republican platform while not quite so verbose was equally evasive as to just what the party proposed to do. It pledged the party to correct the irregularities of the tariff, "not by the vicious and indiscriminate process of horizontal reduction," but by some unstated method which would "relieve the taxpayer without injuring the laborer or the great productive interests of the country." It declared that duties should be levied " not for revenue only" but so " as to afford security to our diversified industries 
and protection to the rights and wages of the laborers." The single definite proposal was that the duties on foreign wool should be raised. ${ }^{1}$

(The two parties were evidently agreed that the tariff should be reformed and that the surplus should be done away with-although neither of them had done anything to accomplish this. In brief, the Republicans proposed that "requisite" duties should be levied in such a way as to protect capital and labor; the Democrats insisted that duties " not to exceed the needs of the government economically administered" should be levied in such a way as to have the same effect. To experts in platform-making the difference here may be obvious but to the lay mind it is not easily apparent.

1 Stanwood, Hist. of the Pres., p. 429. 


\section{CHAPTER VII}

The Issues in i884-Minor Issues and Minor Parties

Although there was little difference between the parties in their attitude toward civil service reform and the tariff, there was even less on other questions. The southern question, while still useful for Republican politicians, was no longer a live issue. Upon the withdrawal of federal troops from the southern states by Hayes, the whites had regained control of the state governments and were able to make ineffective the attempts at federal interference in elections. The attack by the Democrats on the election laws during Hayes' administration was caused more by a desire to strike at the power of the Republican party in the South than by any real oppression resulting from those laws, and the desire to safeguard patronage rather than a belief that the laws were any great aid to the negroes was the reason for the stubborn defense of them made by the Republicans. The Supreme Court had helped to take the southern question out of politics by declaring unconstitutional important sections of the Force Acts, thereby considerably limiting the sphere of federal action in the control of conditions in the South. ${ }^{1}$

John Sherman made an attempt to revive the sectional issue in 1884 by the introduction of a resolution in the Senate on January 25 , instructing the committee on privileges and elections to investigate the outbreak of violence

${ }^{1}$ Dunning, Essays on the Civil War and Reconstruction (ed. of I910), p. 364 . 
in connection with the elections of $\mathrm{I} 883$ in Copiah county, Mississippi, and at Danville, Virginia. ${ }^{1}$ It was charged that in Copiah county there had been an attempt by organized groups of night riders to intimidate the negroes and on electi-n day a prominent Republican leader had been murdercl in the act of casting his ballot. At Danville there had occurred, a few days before the election, a riot between blacks and whites in which four negroes were killed and several others wounded. The Democrats in caucus decided not to oppose the investigation, as any opposition would react unfavorably upon themselves, and the resolution was passed. $^{2}$ The committee, which was composed of Cameron, Frye, Hoar, Lapham and Sherman, Republicans, and Saulsbury, Jonas, Pugh and Vance, Democrats, took some 2,000 pages of testimony, a sub-committee going to New Orleans for the purpose of examining witnesses about the occurrences in Copiah. Much of the testimony, as was usual in the case of such investigations, was flatly contradictory. The partisan character of the whole affair was shown by the attitude of the committee members during the investigation and by the frankly partisan character of the reports, a majority report signed by all the Republicans and a minority report signed by all the Democrats, being submitted in each case. ${ }^{3}$ Although there were several trained lawyers of both parties on the committee, there was no attempt at a careful analysis of the testimony, each side accepting that which served its own purpose and drawing its conclusions accordingly.

The majority reports declared that the evidence showed widespread conspiracies to deprive the negro of his vote, and recommended another investigation after the election

${ }^{1}$ Cong. Rec., 48 C., I S., p. 588.

${ }^{2} N$. Y. Times, Jan. 30, 1884 .

${ }^{3}$ Sen. Reps., 48 C., I S., nos. 521, 579. 
of 1884 , with the threat of a reduction of representation in case the conditions continued. The minority asserted that the evidence showed no grounds for interference by Congress and that the disturbances were only such as might occur, and in fact were constantly occurring, in any northern state. They cited as an illustration the riot which had taken place in Cincinnati at the very time that the committee was holding its hearings, when an armed mob attempting to remove prisoners from the jail had been overpowered by state troops after several days' street fighting with considerable loss of life. ${ }^{1}$

Some of the Republican newspapers, notably the New York Tribune, devoted a good deal of space to the committee hearings, ${ }^{2}$ but the public was not greatly interested. The investigation was generally recognized for what it was -an attempt to make campaign material for the Republicans. ${ }^{3}$

Both parties expressed in their platforms some highsounding and quite indisputable sentiments as to the southern question, but both were rather indefinite as to what they proposed to do. The Republicans declared that the people of the United States "constitute a nation and not a mere confederacy of states," but that the rights of the states " should be faithfully maintained." They further declared that the "perpetuity of our institutions rests upon the maintenance of a free ballot, an honest count, and correct return," and denounced the Democratic party as being the guilty recipient of the fruit of fraud and violence in the southern states. They pledged themselves to the passage of such legislation as would " secure to every citizen, of whatever race and color, the full and complete recognition,

1 Ann. Cyc., 1884, p. 630.

${ }^{2}$ N. Y. Tribune, Feb. 17, 18, 19, et passim, 1884 .

Nation, Jan. 3I, I884. 
possession, and exercise of all civil and political rights." Similarly the Democrats declared it to be the duty of the government "to mete out equal and exact justice to all citizens of whatever nativity, race, color, or persuasion, religious or political." They also asserted their belief in "a free ballot and a fair count" and, as a proof that a Democratic administration would "preserve liberty with order," 1 recalled their efforts to make illegal the presence of troops at the polls.

It was reasonably certain that if the Republicans gained full control of the government they would, for partisan purposes, attempt to extend the system of federal control: and that the Democrats, given the same opportunity, would, for the same reason, do away with what was left of it. Although the voters were not greatly interested in this proposition, the memory of the past record of the Democrats still lingered to weaken them, especially in the minds of the older generation. The feeling that the Democrats were not entirely worthy of confidence was present, although it would have been difficult to justify it by showing any specific way in which they were dangerous. This distrust of the Democrats could not be entirely eradicated until they had been returned to power and given an opportunity to do their worst. The occasional revival of stories of southern outrages was well calculated to keep this vague prejudice alive.

The currency question was not an issue in 1884 . The great increase in the amount of currency in circulation, due to the coinage of silver and the decreased demand for it resulting from business depression, ${ }^{2}$ had quieted the demands of the greenbackers. Both parties were quite content to

'Stanwood, Presidency, pp. 43I, 437.

2 U. S. Treasurer's Rep., I884, pp. xxx-xxxv ; Com. \& Fin. Chronicle, Jan. 17,1885 . 
leave the greenback situation as it was. Although the coinage of silver under the Bland-Allison act threatened difficulties, opinion on the silver question had not yet crystallized, and such opinion as there was did not run along party lines. President Arthur had in his first and second annual messages urged the repeal of the Bland-Allison act but no action had resulted. ${ }^{1}$ While the Democrats could be counted on to furnish more votes than the Republicans for any proposition to increase the amount of silver coin, votes in Congress on the silver question had been mainly nonpartisan. $^{2}$ Of a similar nature was the attitude of the Democrats toward the national banking system. Hostility to the national banks on the part of some Democrats, especially those from the West and South, cropped out at different times but it did not extend to all members of the party. ${ }^{3}$ The currency planks in the platforms of both parties were practically the same. The Republicans urged an international standard to fix the relative value of gold and silver. The Democrats asserted their belief in "honest money, the gold and silver coinage of the constitution." 4

Except at rare intervals when some international crisis. has overshadowed all other issues, the conduct of foreign affairs has played but little part as an issue in Presidential campaigns. The campaign of 1884 was no exception to the general rule. The questions of American control of a canal across the isthmus and of building up closer relations with South America were beginning to be of general interest and on these both parties were agreed. Both in their plat-

${ }^{1}$ Richardson, vol. viii, pp. 46, I33.

${ }^{2}$ Sparks, op. cit., p. 143 et seq.; McPherson, I880, pp. 46, I45, I882, p. 28,1884 , p. 143 .

${ }^{3}$ McPherson, I882, p. 134, I884, p. I43; Sherman, Autobiog., vol. ii p. 877.

4 Stanwood, Presidency, pp. 430, 437. 
forms announced their purpose to refrain from any interference in foreign affairs and to cultivate closer relations with the nations of the western hemisphere. ${ }^{1}$ Such interest as there was in foreign relations in the campaign centered in Blaine's record as Secretary of State. ${ }^{2}$

The old parties were slow to take up the questions raised by the new economic conditions that had developed. ${ }^{3}$ There was little well-informed public opinion on them and there were powerful interests opposed to any action. Neither party, however, could afford to ignore the elements of discontent, and each posed as the friend of the farmer and the workingman. The Republicans based their claim on the fact that they were the originators of the homestead laws and that the system of protection had been developed mainly in the interest of labor. The Democrats declared that they were traditionally the party of the common people while the Republicans had always been the party of special privilege. The record of party action in Congress did not bear out the claim of either party. Neither party had any definite policy toward the problems of either the farmer or the laborer and such bills as were passed dealing with these questions were passed by non-partisan votes. ${ }^{4}$

The failure of the old parties to meet the new issues caused the formation of several new parties in the two decades following the war. As the purchasing power of the dollar continued to grow and to bear more and more heavily on the debtor West the demand for greenbacks became insistent. Many communities in the Middle West formed separate political organizations to promote the greenback idea. Various farmers' organizations in the same region

1 Stanwood, Presidency, pp. 431, 437, 438.

'Vide infra, p. I49.

${ }^{3}$ Vide supra, p. I6.

- McPherson, 1876-1884, passim. 
formed local or state parties in the seventies, mainly to demand government regulation of railroads and forfeiture of land grants to corporations. These anti-monopoly parties, as they were called, were usually in their origin distinct from the greenback parties, although fusion between them was common. ${ }^{1}$

Labor for the most part had kept aloof from politics, preferring straight trade-union methods. This was the traditional policy of the Knights of Labor, the strongest labor organization of the period. ${ }^{2}$ There was always, however, a minority which was anxious to use political methods and form a national labor party. A group of labor leaders and intellectuals held a convention in 1872 and under the name of the National Labor Reform party nominated David Davis for the Presidency. Davis declined the nomination and Charles O'Conor was substituted. His vote was negligible and discouraged further attempts to form a separate labor party. ${ }^{3}$

There was a tendency for these various elements of discontent to unite in one party. The hard times following the panic of 1873 increased dissatisfaction with the old parties and in 1876 a national greenback convention was held. This convention was attended both by representatives of farmers' anti-monopoly organizations and by labor leaders. but the currency question was the main issue and it was from the greenbackers that Peter Cooper, the nominee for the Presidency, drew most of his support. ${ }^{4}$ The labor trouble of 1877 turned labor more strongly to the Green-

'Buck, The Granger Movement, pp. 80-10I.

"Powderly, Thirty Years of Labor, p. 239.

${ }^{3}$ Commons (and associates), History of Labor in the U. S., vol. ii, pp. 43, 96, II5, I24, I5I-155; Ely, Labor Movement in America, pp. 6I-69.

${ }^{4}$ Commons, op. cit., vol. ii, pp. 168-240; Lalor, Cyc. of Pol. Sci., p. 418; Ann. Cyc., 1876, p. 781. 
back party and were partly responsible for the $1,000,000$ votes polled by the party in 1878 . In 1880 , however, the accomplishment of resumption, the increase in the volume of currency due to coinage of silver and the renewed industrial prosperity lessened the force of the appeal of the greenbackers. Their convention was made up of greenbackers, anti-monopolists, labor leaders, socialists and various other reformers with special hobbies. Their platform devoted less attention to the currency and advocated a long list of reforms in an evident attempt to appeal to all the elements of discontent in the country. In spite of this fact, the party polled less than a third of the vote it had received in $1878 .^{1}$

After I880 two opposite tendencies developed in the labor movement. One was that toward a growing class consciousness and a semi-socialistic program which was greatly strengthened by the wide dissemination of Henry George's book, Progress and Poverty, and which became more noticeable in the period of business depression starting in I 882. ${ }^{2}$ The other was the tendency of the skilled workers organized in trades unions toward a closer federation and a policy of refraining from independent political action while attempting to bring pressure to bear on the existing parties. The Federation of Organized Trade and Labor Unions of the United States and Canada, the immediate predecessor of the present American Federation of Labor, was formed in $188 \mathrm{I} .^{3}$

The business depression which had started in 1882 and grown steadily worse ${ }^{4}$ had seriously affected labor engaged

${ }^{1}$ Commons, op. cit., pp. 246, 269-290; Hillquit, History of Socialism in the U. S., p. 266; Stanwood, Presidency, p. 419.

${ }^{2}$ Ely, Recent American Socialism, p. 16.

${ }^{3}$ Commons, op. cit., pp. 319-330.

-Vide supra, p. I21. 
in manufacturing. Bradstreet's estimated that during the year 1883 wages had been reduced from ten to twenty percent in most of the important industries of the country and that there had been a reduction of ten percent in the number of men employed in these industries. ${ }^{1}$ Conditions grew still worse in 1884 . After a careful inquiry conducted in the twenty-two most important manufacturing states and a comparison with the census reports of 1880 , with due allowance for the increase that had taken place up to I882, $\mathrm{Brad}$ street's reported that there had been an average reduction in wages of from twenty to twenty-five percent, and in certain industries as much as thirty-five percent. The reduction in working force varied from thirty-three to twenty percent in different industries. Not counting the large reduction of clerical forces in mercantile establishments, it was estimated that there were at least $35^{\circ}, 000$ fewer persons employed in manufacturing than there had been in 1882 . The number of these who had found employment in other lines was not known. ${ }^{2}$ Under these circumstances it was felt that the labor vote would play an unusually important part in the Presidential campaign.

An Anti-Monopoly convention was held in Chicago, May I4, I884. Only I 38 delegates, representing farmers' organizations for the most part, were in attendance from twenty-one states, and the convention attracted but little attention in the East. ${ }^{3}$ It adopted a platform which contained a comprehensive plan for the protection of "the rights of all against privileges of the few." Regulation of interstate commerce was declared to be the immediate and imperative duty of Congress. Forfeiture of land grants to corporations, labor legislation, payment of the debt as it

1 Bradstreet's, Feb. 23, I884.

${ }^{2}$ Ibid., Dec. 20, I884.

${ }^{3}$ N. Y. Sun, May 15, 1884; Commons, op. cit., p. 440. 
came due, direct election of U. S. Senators, a graduated income tax and a revision of the tariff in the interests of labor instead of capital were advocated. The platform closed with a demand that agriculture be given the "fostering care of the government" and an appeal to farmers to unite with the party for the overthrow of monopoly. ${ }^{1}$

The Greenback convention held in Indianapolis on May 28 of the same year was made up of all sorts of reformers and their platform covered a wide range of subjects. It declared the recent decision of the Supreme Court ${ }^{2}$ to be a full vindication of their theory of money and demanded the issue of greenbacks in "sufficient quantities to supply the actual demands of trade," and the substitution of greenbacks for national bank notes. The larger part of the platform, however, was devoted to plans for improving the condition of the workers and limiting special privilege. It demanded government regulation of all monopolies, especially of railroads, and a graduated income tax. It declared in favor of submitting the questions of woman suffrage and prohibition to popular vote. While favoring a revision of the tariff, it declared that the tariff was of secondary importance to the financial question and that it was used by the old parties to distract attention from the main issue. ${ }^{3}$

Both the Anti-Monopoly and the Greenback parties showed their poverty of leadership and their willingness to subordinate principle to temporary advantage by the nomination of Benjamin F. Butler for the Presidency. Butler had had a variegated career. For more than a quarter of a century he had been a national figure as a bourbon Democrat before the war, a major-general in the war charged

'Stanwood, Presidency', p. 422.

2 Juilliard $v$. Greenman, I Io U. S., p. 42 I.

${ }^{8}$ Stanwood, Presidency, p. 423. 
with inefficiency and dishonesty, and a leader of the radical Republicans in the days of reconstruction. After several attempts to get the Republican nomination for governor of Massachusetts, he had run as an independent, had secured Democratic endorsement and had finally been elected in 1882 as a Democrat. Although he had long proclaimed himself the friend of the workingman and the foe of special privilege, there was little in his record as Congressman, governor or employer that would indicate that his real interest in labor went farther than a desire to gain its favor for his own ends. His main claim to the support of the workingman, as given by one of his supporters in the campaign of 1884 , was that "all the snobs and all the dilettantes hate him, and Harvard College won't make him a doctor of laws." 1

Butler's nomination by both parties was a foregone conclusion and was evidently the result of careful planning by his lieutenants. ${ }^{2}$ It was brought about without difficulty, but several delegates withdrew from the Anti-Monopoly convention, declaring that it had been packed for Butler," and a considerable minority among the Greenbackers opposed him and refused to make his nomination unanimous. ${ }^{4}$ He did not definitely accept either nomination until August. In response to an inquiry as to whether he would accept the Greenback nomination, he refused to commit himself but gave the impression that he would. ${ }^{5}$ His plan was evi-

1 Address of H. J. Clark, campaign document of Peoples Party I884; for accounts of Butler vide Butler's Book; Hoar, Autobiog., vol. i, p. 363; Rhodes, Hist. of U. S., vol. v, p. 312; The Record of B. F. Butler (campaign pamphlet); N. Y. Times, Jan. 3, July 19, Nov. 4, 1884.

${ }^{2} N$. Y. Sun, May 26, 28, 1884.

${ }^{3} N$. Y. Times, May 19.

'N. Y. Sun, May 30.

${ }^{5}$ Ibid., May 29. 
dently to work with Tammany to defeat Cleveland ${ }^{1}$ and to bully the Democrats into nominating him by threatening them with the loss of the labor vote. ${ }^{2}$

The Knights of Labor had representatives at the Republican convention to urge the claims of labor. ${ }^{3}$ There was also present a delegation from Typographical Union No. 6 of New York city to urge the convention to repudiate Whitelaw Reid and the New York Tribune, on whom the union had declared a boycott because of the discharge of union printers in violation, the union claimed, of an agreement between Reid and itself. When neither group received much attention from the convention, the New York union voted to fight Blaine in the campaign. ${ }^{4}$

+ Both the major parties devoted considerable space in their platforms to the questions with which the minor parties were mainly concerned, but both were vague in their positive recommendations and there was no distinct issue between them. Both declared for the policy of preserving the public lands for actual settlers and of revoking where possible existing grants to corporations. The Democrats declared that they favored all legislation which would tend "to the prevention of monopoly, and to the strict enforcement of individual rights against corporate abuses," but that "the welfare of society depends upon a scrupulous regard for the rights of property as defined by law." The Republicans more definitely declared in favor of federal regulation of railroads in such a way as to "secure to the people and to the railways alike the fair and equal protection of the laws." Both asserted at length their devotion

${ }^{1}$ Schurz, Works, vol. iv, p. 213.

${ }^{2}$ Cf. infra, p. 184 .

${ }^{3}$ Nation, June 5.

${ }^{4}$ Hist. of Typo. Union No. 6, p. 388-in Report of N. Y. State Dept. of Labor, 1912. 
to labor, their intention to revise the revenue laws with the welfare of labor chiefly in mind, and their opposition to the importation of Chinese labor or other labor under contract. The Republicans came out definitely in favor of the establishment of a national bureau of labor and the enforcement of the eight-hour law. The Democrats declared that labor should be "fostered and cherished" and favored laws by which labor organizations might be incorporated.

Another issue that had an important bearing on the result -4 of the campaign, although not an issue between the major parties, was that of prohibition. The question of control of the liquor traffic had become a vital one in several states and had played an important part in the elections of 1882 . In the election of 1883 in Ohio it was generally considered to have been the main factor in the Democratic victory. ${ }^{1}$ The Democratic party had consistently taken the position in their state platforms that control of the liquor traffic was not a proper subject for legislation. The Republicans, while not taking a definite stand for prohibition, had not opposed it, their usual tactics being to favor the submission of the question to the voters. The question had come up in Congress at different times, mainly in the form of attempts to have special or standing committees appointed to deal with the question. The support for these motions came mainly from the Republicans and the opposition from the Democrats. ${ }^{2}$ The Republicans ignored the question in their platform for I884, but the Democrats put in a plank announcing their opposition to "sumptuary laws which vex the citizens and interfere with personal liberty."

The first national party on the temperance question was formed in 1872 under the name of the National Prohibition Party and polled 5608 votes in the Presidential election of

1 Vide supra, pp. 71, 77.

${ }^{3}$ McPherson, I876, p. I99, I882, p. II8, I884, p. I90. 
that year. Their vote in 1876 was 9522, and in 1880 , I0,306. ${ }^{1}$ The convention of I884 was held in Pittsburgh, July 23, and nominated John P. St. John, formerly Republican governor of Kansas, who had been defeated in 1882 on the prohibition issue. ${ }^{2}$ St. John had made a good record as governor and was a forceful speaker and a good campaigner. The Prohibition platform was a well-written document presenting a definite program. It pictured the evils of intemperance and demanded, as first steps in its abolition, that the government abandon the taxes on liquor and tobacco, that Congress prohibit the manufacture and sale of liquor in the District of Columbia and the territories and that no state be admitted to the union until its constitution prohibited the manufacture and sale of liquor. It condemned the Republican party for not having done anything to check the liquor traffic in all the years of its power and condemned its nominees for having shown their friendliness to the liquor interests by propositions for such a use of revenue as would necessitate the perpetuation of the tax on liquors. ${ }^{3}$ The Democratic party was condemned as a matter of course for its declared opposition to sumptuary laws. In addition to the planks on prohibition, the platform declared for civil service reform, retention of public lands for the people, a liberal pension system and woman suffrage. It repudiated as un-American the doctrine that any "person or people shall or may be excluded from residence or citizenship." 4

${ }^{1}$ Stanwood, Presidency, pp. 352, 383, 417; Black, History of the National Prohibition Party.

2N. Y. Times, July 25.

Blaine had suggested the distribution of the surplus among the states. Vide supra, p. I24. Logan had introduced a bill providing that the revenue from the liquor taxes be used for the support of schools. Cong. Rec., 47 C., I S., pp. 266, 401.

4 Stanwood, Presidency, p. 442. 
As has been previously indicated, the platform declarations of the two major parties on the tariff, civil service reform, the currency, foreign policy, labor problems, control of interstate commerce, public lands, and the Southern question, although different in phraseology, when reduced to programs of action were practically the same. There was no real issue between them on other questions. Both declared in favor of pensions, of choosing territorial officials from actual residents of the territories, and for the building up of the merchant marine. An increased navy and the suppression of polygamy in the territories were demanded by the Republicans and not mentioned by the Democrats, while the question of improvement of internal waterways was dealt with only by the Democrats. None of these questions was important enough, however, to be called an issue. It was only in praise of itself or in the arraignment of its opponents that either party was definite and positive. The Democrats gave a long and detailed table of the sins of omission and commission of the Republicans, ending with the declaration that "honey-combed with corruption, outbreaking exposures no longer shock its moral sense. Its honest members, its independent journals, no longer maintain a successful contest for authority in its canvasses or a veto upon bad nominations." The Republicans, as usual, "pointed with pride" to their record and endorsed the administrations of both Garfield and Arthur. The Nation declared that the platforms " draw no dividing line of principle or policy upon either side of which the voter may be sure that he is casting his influence in favor of one set of ideas as opposed to another. . . . The Republican party,' says the Democratic platform, 'so far as principle is concerned, is a reminiscence.' Quite true. The Democratic party is another." ${ }^{-}$The Independent said, 
"Their platforms are in both cases mere political speeches, differing only in the skill with which they praise themselves, abuse the other party, throw out bait to catch selfish votes, and juggle with terms to evade a statement of principle, when they have none to state." ${ }^{1}$

${ }^{1}$ July I7. 


\section{CHAPTER VIII}

\section{The Republican Nomination \\ 11}

The two leading candidates for the Republican nomination in 1884 were Arthur and Blaine. Although the factions within the party were not as clear-cut or as well organized as in 1880 , these two men stood out as the leaders respectively of the Stalwarts and the Half-Breeds. The dispute between Garfield and Conkling which ended in Conkling's retirement from politics, the stigma which attached to the Stalwarts of partial responsibility for the state of affairs that led to Garfield's death, the uprising against the Camerons in Pennsylvania in I882, and finally Arthur's refusal to use his office to build up one faction of the party, all combined to leave the Stalwarts without strong leadership or organization. Garfield's untimely death had also deprived the Half-Breeds of an opportunity to use the patronage to build up their organization. The Independents had developed no leader among their own number who was popular enough to be seriously considered, but results in 1882 had shown that they were a force to be reckoned with.

Various candidates were discussed and favorite sons brought forward, but none of them except Arthur and Blaine developed strength enough to be a real contender for the nomination. Senator Edmunds of Vermont was the Independent's choice but he was from a small state and was not widely known or popular. The same objections held against Senator Hawley of Connecticut. John Sherman 
was strong in Ohio but made no great impression outside. Logan of Illinois likewise had considerable local strength but little national. Gresham of Indiana, Arthur's Postmaster-General, was spoken of but was not widely known. General W. T. Sherman was objectionable because of the fact that his wife was a Roman Catholic and he positively refused to be considered. ${ }^{1}$ Practical politicians were willing to admit the weaknesses of either Blaine or Arthur but could see no other available candidate. ${ }^{2}$

It was the general consensus of opinion that Arthur's record as President would compare favorably with those of the great majority of his predecessors. He refused to use his office for partisan purposes although under strong pressure to do so. His appointments in the main were good. His utterances on matters of public policy were intelligent and courageous. His conduct at all times was dignified. His administration was free from scandal. ${ }^{3}$ Every Republican state convention held in 1884 endorsed his administration. ${ }^{4}$ Although 196 of his 278 votes on the first ballot at the national convention came from the southern states whose delegates were named by Republican office-holders, there is no evidence that Arthur used his office to force his renomination. ${ }^{5}$ Robertson, collector of the port of New York, was an active supporter of Blaine and was present at the convention working for Blaine.

Arthur was especially strong with business men, who felt that they should leave well enough alone. A meeting of

${ }^{1}$ Hamilton, Blaine, p. 625 .

'Schurz, Works, vol. iv, p. 202, letter of Plumb.

${ }^{3}$ McCulloch, Men and Measures of Half a Century, p. 484; Peck, Twenty Years, p. 4; Rhodes, article in Scribner's, Sept. I9I I.

«Official Proceedings of the Eighth Rep. Nat. Conv. (Chicago, 1884), pp. III, II4.

${ }^{5}$ Rhodes, op. cit. 
business men of New York city, held at Cooper Union, May 20 , adopted resolutions commending his administration and urging his renomination. A delegation of New York business men went to the convention to further his candidacy. ${ }^{1}$ His strength with the business interests was turned against him at the convention, where the Blaine supporters charged that his candidacy had a "flavor of Wall St. about it." "

Arthur's great weakness as a candidate was that he was not a good self-advertiser. There had been nothing spectacular in his administration. His lack of partisanship, whether it was due, as his friends said, to a desire to be fair to all factions whatever the cost, or as his enemies said, to his attempts to please everybody, was a source of weakness. Admirers of Garfield could never quite forgive Arthur for having gained the Presidency through Garfield's assassination. $^{3}$ Only by leaving the administration entirely under Blaine's control could Arthur have satisfied the HalfBreeds. They declared that he failed to measure up to the standard set by Garfield and that his re-election was impossible. ${ }^{4}$ His failure to make a complete sweep of HalfBreed office-holders alienated the Stalwart leaders. ${ }^{5}$ Practical politicians pointed to the overwhelming defeat of Folger, his candidate in New York in I882, as evidence of his weakness. The Independents, while conceding many of Arthur's good points, were not enthusiastic about him. G. W. Curtis, president of the National Civil Service Reform League, said in his address to the league, August 6, I884,

${ }^{1} N$. Y. Times, April I3, May 21, 31, 1884; Schurz, Works, vol. iv, p. 202.

'Leslie's History of the Rep. Party, vol. i, p. 432.

${ }^{3}$ Schurz, Works, vol. iv, p. 202.

- Sherman, Autobiog., vol. ii, p. 886; Hoar, Autobiog., vol. i, p. 405 ; N. Y. Tribune, Jan. 28, et passim.

${ }^{5}$ Platt, Autobiog., p. I80; Boutwell, Reminiscences, vol. i, p. 275; Peck, Twenty Years, p. II. 
" his honorable treatment of the new policy [civil service reform] is one of his chief titles to public regard . . . his candor and good faith secured the fair trial of the new system." 1 Many could not forget, however, that he had been a machine politician and had stood for years for all the things that they were opposed to. There was always in their minds the suspicion that in endorsing reform he was merely making a virtue of necessity and that his conversion might not be lasting. His general good record in appointments was marred by a few conspicuously bad ones. The effect of his refusal to play politics in most cases was spoiled by a few isolated acts such as his aid to the Mahone machine in Virginia and his interference in the New York election of $1882 .^{2}$ The Independents, although they were hostile to Arthur early in the campaign, greatly preferred him to Blaine, and as Blaine's strength increased they showed inclinations to turn to Arthur. The Independent leaders in the convention would have been glad to unite on Arthur as a last resort to defeat Blaine. ${ }^{3}$

The candidate who figured in all calculations, and whe everyone admitted, either gladly or with regret, was bound to be strong, was Blaine. His arch enemy Conkling was no longer active and he had the support of several men who had opposed him formerly. The Chicago Tribune and the Cincinnati Commercial, two powerful middle-western newspapers which had formerly opposed him, now supported him. ${ }^{*}$ The argument, however, which had done most to prevent his nomination in 1876 and 1880 , his railroad transactions, although old, had never been satisfactorily an-

${ }^{1}$ N. Y. Times, Aug. 8.

${ }^{2}$ Nation, March 2, April I3, June I, I882, Nov. 22, I883, April I7, 24, May I, I884; $N$. Y. Times, April 8, June 9, 1884; Cary, Life of G. $W$. Curtis, p. 287.

: Harper's Weekly, June 14.

${ }^{4}$ Stanwood, Blaine, p. 183. 
swered and was sure to be brought up against him. Since I876 he had done little to add to his reputation. He had been elected to the Senate to fill out Morrill's term and reelected to succeed himself. In the Senate he played a minor part, never acquiring the influence or the reputation that he had in the House. ${ }^{1}$ He was Garfield's close adviser in the campaign of 1880 and was made Secretary of State.

Blaine's record as Secretary of State gained him publicity but was not such as to strengthen him with students of public affairs. He was the leader of the group that demanded what it called a vigorous foreign policy, which his opponents declared consisted in adopting a bullying attitude toward the small Latin-American states and a truculent attitude toward any European country that seemed inclined to interfere. Blaine, according to his friends, was one of the few men of sufficient vision to see the real destiny of the United States among nations and to have a plan which would enable her to play the part that she should as the leader of the western hemisphere. The declared purpose of Blaine's policy was to bring about peace and prevent future wars in North and South America and to build up friendly relations with the Latin-American countries which would greatly increase the export trade of the United States. ${ }^{2}$

One of Blaine's problems as Secretary of State was the delicate one of adjusting the trouble between Chili and Peru, which had been at war with each other for more than two years. Peru possessed lands with valuable deposits of nitrates and guano which Chili coveted and in which various individuals, including some who claimed to be citizens of the United States, were financially interested. Blaine's

1 Stanwood, Blaine, pp. I88-215.

${ }^{2}$ Blaine, "The Foreign Policy of Garfield's Administration," in Chicago Weekly Magazine, Sept. I6, I88I, also published as a pamphlet; Hamilton, Blaine, p. 504; Stanwood, Blaine, p. 24I. 
motives in the matter have been attacked, and while any definite proof of dishonest ones is lacking, the charge that he forced the recognition of a government in Peru that had not even a de facto existence, and adopted a dictatorial attitude toward Chili which lessened the chances for peace and caused suspicion of the United States on the part of South American countries, seems to be justified. ${ }^{1}$ When Frelinghuysen took over the duties of Secretary of State he adopted a much milder tone toward Chili and revoked part of the instructions of Trescott, the special minister whom Blaine had sent to Chili. ${ }^{2}$

Blaine was also criticized for his interference in the boundary dispute between Mexico and Guatemala. Although the note which he sent to Mexico was rather dictatorial, there seems to have been no serious breach of international etiquette. ${ }^{3}$

Blaine's pet scheme for Latin-America was his peace congress. Invitations were sent out in November, I88I, to the various countries of South and Central America to participate in a general congress to be held at Washington. The call for the congress announced that "its sole aim shall be to seek a way of permanently averting the horrors of cruel and bloody combat between countries, oftenest of one blood and speech, or the even worse calamity of internal commotion and civil strife." 4 Blaine's opponents charged that, however laudable the desire to bring about peace might be,

${ }^{1}$ U. S. Foreign Relations, I88I, passim; Sen. Ex. Doc., 47 C., I S., no. 79; House Rep., 47 C., I S., no. I790; Ann. Cyc., I882, p. 810; pamphlets published during campaign of 1884 -Hurlburt, Meddling and Muddling, de Leon, A Specimen of Mr. Blaine's Diplomacy, Hall, Blaine and His Foreign Policy; Nation, Dec. 15, I88r, Feb. 2, May 5, Aug. I3, 1882, Sept. I8, 25, Oct. 2, I884; Independent, Oct. 30, I884.

${ }^{2} U$. S. Foreign Rels., I882, p. 57.

${ }^{3}$ For. Rels., I88I, p. 766 et seq.; also pamphlets referred to supra.

4 For. Rels., I881, p. I4. 
this was but another of his devices for self-advertising. They quoted the phrase about internal commotions to show that it was a scheme to give the United States an excuse to interfere in the affairs of smaller nations for the benefit of business interests. Blaine's continued insistence on the great benefits to trade to be derived from his policy give some force to this accusation.

Blaine had instructed Trescott, the special minister to Chili, to visit other South American countries in the interest of the congress. Frelinghuysen in a note to Trescott on January 9, I882, cancelled that part of his instructions, saying:

The United States is at peace with all the nations of the earth and the President wishes hereafter to determine whether it will conduce to that general peace, which he would cherish and promote, for this government to enter into negotiation and consultation for the promotion of peace with selected friendly nationalities without extending a like confidence to other peoples with whom the United States is on equally friendly terms. . . . The principles controlling the relations of the republics of this hemisphere with each other and with other nationalities may, on investigation, be found to be so well established that little could be gained at this time by reopening a subject which is not novel. The President at all events prefers time for deliberation. ${ }^{1}$

In a special message, April 18, I882, Arthur included a copy of the invitation to the proposed peace congress and, announcing that the differences between the South American states, which he had hoped would be settled, still continued, referred to Congress the propriety of proceeding with the enterprise. ${ }^{2}$ The invitation was withdrawn by

${ }^{1}$ For. Rels., I882, p. 57.

2 Richardson, vol. viii, p. 97. 
Frelinghuysen in a note to the various ministers dated August 9. ${ }^{1} \quad$ Arthur announced in his message of December, I882, that the invitation had been withdrawn because the war between Chili and Peru still continued and Congress had taken no action on his message of April and made no provision for the expenses of the congress. ${ }^{2}$ Blaine attacked the administration for reversing his policy. In an open letter to President Arthur and in newspaper interviews he declared that the withdrawal of the invitation was a "voluntary humiliation of this government before European powers." 3

Blaine for some reason or other seemed to have a strong bias against all things British. ${ }^{4} \mathrm{He}$ found an opportunity to give vent to his feelings against England in connection with the controversy over the isthmian canal. Interest in the canal had been revived by the activities of the De Lesseps company. The Clayton-Bulwer treaty with England stood in the way of a canal built and controlled by the United States. Blaine hit upon the expedient of getting around the Clayton-Bulwer treaty by completely ignoring it. In a note, June 24, 188I, sent to the envoys at the various European capitals to be delivered simultaneously, he said that it had fallen under the observation of the President that the great powers of Europe might possibly be considering the question of the joint guarantee of the neutrality of an interoceanic canal. He called attention to the treaty of 1846 between the United States and New Grenada, and declared that this

${ }^{1}$ For. Rels., I882, p. 4.

Richardson, vol. viii, p. 130.

${ }^{3}$ Blaine, Foreign Policy of Garfield; Hamilton, Blaine, p. 521 ; Nation, Feb. 9, March 30, 1882.

'Vide e. g. Blaine, Twenty Years, chap. xx; House Reps., 47 C., I S., no. I790, p. 217, testimony of Blaine. 
guarantee, given by the United States of America, does not require any re-enforcement, or accession, or assent by any other power. . . . Any attempt to supersede that guarantee by an agreement between European powers . . . whose interests in the canal and its operation can never be so vital and supreme as ours would partake of the nature of an alliance against the United States and would be regarded by this government as an indication of unfriendly feeling. ${ }^{1}$

No mention whatever was made of the Clayton-Bulwer treaty in this remarkable note. Lord Granville made no reply for several months, and then in a curt note called attention to the Clayton-Bulwer treaty and said that Her Majesty's Government relied with confidence upon the observation of all the obligations of that treaty. ${ }^{2}$ In a supplementary note which was sent before Granville's was received, but not until five months after the first, Blaine took up the Clayton-Bulwer treaty and gave reasons why the United States wished it abrogated. He said that by reason of Britain's large navy the two nations were not left on a basis of equality in regard to the canal. The general tone of the note may be judged by the following extract: "The military power of the United States, as shown by the recent Civil War, is without limit and in any conflict on the American continent altogether irresistible." '3 Blaine's argument amounted to a "statement that the United States having found the obligations of its contract irksome, and antagonistic to its new political policies, it therefore deemed it fitting and proper to avoid them." " It was a novel way for a nation to go about securing the favor of the modification

1 For. Rels., I88I, p. 537.

2 Ibid., p. 549.

${ }^{3}$ Ibid., p. 554 .

- Henderson, American Diplomatic Questions, p. I47; vide also Latané, Diplomatic Relations of the U.S. and Spanish America, p. 208. 
of a treaty from a friendly power. The Economist (London) of December 24, I88I, said:

It is difficult for Englishmen to read such a dispatch unmoved, and to repress the inclination to answer it by a definite refusal to modify the Clayton-Bulwer treaty, leaving the Government at Washington to take such steps as they may deem expedient. It is vain, however, for nations to give way to temper; the evidence that the wording of the dispatch is intended to please Americans rather than to displease Englishmen is very strong, and in the interest of both nations it is wiser to regard only the substance of the request thus rudely pressed upon Britain's attention. ${ }^{1}$

It is not to be wondered at that the English newspapers were not enthusiastic about Blaine's candidacy. His friends, however, attributed their hostility to "English free-trade spite." 2

Another question that Blaine had to take up with England was that of American citizens imprisoned in Ireland. The Irish vote was considered to be one of the great elements in Blaine's strength. This was apparently due to the general belief that he had been particularly active while Secretary of State in protecting the rights of American citizens imprisoned in Ireland. An examination of the records, however, reveals no basis for this belief. The Coercion Act was passed by Parliament March 2, I88I, and under the authority of this act several persons who claimed American citizenship were imprisoned. Petitions for their release were made by them and their friends to Minister Lowell in London and to the State department at Washington. Steps were taken by the State department through Mr. Lowell to secure to those imprisoned their legal rights, but the doc-

${ }^{1}$ Quoted in Hall, Blaine and His Foreign Policy, p. 20.

${ }^{2}$ N. Y. Tribune, June 25,1884 . 
trine was laid down that every government had the right to administer its own municipal law to all persons within its jurisdiction. During Blaine's term only one person who claimed American citizenship was released, and he was released on the ground of ill-health. Blaine followed Lowell's advice in the matter, approved of his action and adopted his opinion, yet Blaine was held up as the protector of American citizens while Lowell was execrated as the tool of British interests. ${ }^{1}$

A few distrusted Blaine because of his record as Secretary of State and saw in his foreign policy a reckless attempt to cultivate popularity at the cost of the interests of his country. They believed that his policy would involve the United States in needless foreign difficulties. ${ }^{2}$ The great mass of voters, however, knew little and cared less about what foreign policy was adopted. Foreign policy played but a minor part in either the nomination or the election.

After Blaine's retirement on December I9, I88I, from the State department he continued to live in Washington, from where he gave out interviews from time to time, the most of them criticizing the administration for reversing his foreign policy. He began during this period to write his Twenty Years of Congress and during the early months of I884 chapters of his work appeared in the newspapers. Rumors were started at various times that he had retired from politics and intended to devote himself exclusively to literary work. His opponents scoffed at this, declaring that his residence in Washington and his literary work were merely schemes to keep himself before the public. ${ }^{3}$ There is some difference of opinion as to whether Blaine

${ }^{1}$ For. Rels., I88I, pp. I-43; Cong. Rec., 47 C., I S., p. I136; Hall, op. cit.; Nation, Aug. 14, 1884 .

${ }^{2}$ Cary, Curtis, p. 284.

'Nation, April 3, 10, 17, 24, 1884; Hudson, op. cit., p. I27. 
wanted the nomination in 1884 or not. It has been said that he felt that his opportunity was past, that his public life was over and that he really wished to retire, also that he felt that because of the various enmities in the party his nomination in 1884 would be unwise. ${ }^{1}$ In interviews in the latter part of I 883 and early in I 884 he suggested various other candidates, among them Allison of Iowa, Harrison of Indiana, Cullom of Illinois and Miller of California. ${ }^{2}$ He strongly urged Gen. W. T. Sherman to be the candidate. $^{3}$ His friends claimed that in doing this he was sincerely trying to find a suitable candidate and finally consented to be one himself only when he became convinced that no one else could save the party. Blaine wrote, April $2 \mathrm{I}$, I884, "I do not think I shall be nominated, but I am disturbing the calculation of others at an astonishing rate." 4 His opponents refused to believe that he was entirely altruistic in booming other candidates, and insisted that he hoped to gain the good-will of a lot of impossibilities, who, when they saw they had no chance, would gratefully turn to him. ${ }^{5}$ One of Nast's cartoons, entitled "Blaine leans toward Logan," pictured Logan bound hand and foot standing on the steps of the White House and about to be pushed off by Blaine leaning against him. ${ }^{6}$ Just how much Blaine wanted the nomination or what he did to get it is difficult to decide, but he never publicly stated that he would not accept it or took steps to prevent its coming to him.

Blaine's great stumbling-block was the opposition of the

${ }^{1}$ Stanwood, Blaine, p. 268; Rogers, op. cit., p. I47; Rhodes in Scribner's, Sept. I9II.

${ }^{2} N$. Y .Tribune, Nov. I883-Feb. I884; Nation, Jan. Io, 1884.

${ }^{3}$ Hamilton, Blaine, pp. 624, 625.

${ }^{4}$ Ibid., p. 623.

${ }^{5}$ Nation, January Io, April 3, 24, 1884.

'Harpers' Weekly, March I3, I884. 
Independents. The distrust and dislike between them was reciprocal. Blaine either could not or would not understand their point of view or admit that their motives were anything but selfish. ${ }^{1}$ The Independents insisted that with public interest in reform aroused and with the people distrustful of the Republican party as shown by the elections of 1882 , a defensive campaign was out of the question for the Republicans and that the nomination of Blaine would inevitably mean a defensive campaign. The Independents were especially strong in New York, ${ }^{2}$ and the certainty of a solid South for the Democrats made the winning of New York almost a sine qua non of Republican success. ${ }^{3}$ As Blaine's strength increased the efforts of his foes to show his unfitness were redoubled. The New York Times, the Evening Post, the Nation and Harper's Weekly vied with each other in their attacks, republishing the Mulligan letters and raking up all the details of Blaine's record. ${ }^{4}$ Predic-

${ }^{1}$ Blaine, Twenty Years, Remarks on Carl Schurz, p. 438; vide also articles in N.Y. Tribune, May-Aug. I877 by Gail Hamilton, probably inspired by Blaine. Blaine wrote to Garfield, Dec. Io, I880: "The third section [of the Republican party] is the Reformers by profession, the ' unco good.' They are to be treated with respect, but they are the worst possible political advisers-upstarts, conceited, foolish, vain, without knowledge of measures, ignorant of men, shouting a shibboleth which represents nothing of practical reform that you are not a thousand times pledged to. They are noisy but not numerous, pharisaical but not practical, ambitious but not wise, pretentious but not powerful! They can be easily dealt with and can be hitched to your administration with ease. I could handle them myself without trouble. You can do it more easily still."-Hamilton, Blaine, p. 490.

"The Nation by an analysis of the votes of 1882 and 1883 estimated that there were at least 80,000 independent voters in N. Y. Nation, Nov. 29, 1883 .

${ }^{3}$ Schurz, Works, vol. iv, pp. 200, 204.

'Vide files of these journals March-May I884, especially Times, April 15, May 9; Evening Post, April 17, 27, 28; Nation, April 24, May I, I5; Harper's Weekly, Feb. 23, March 29. 
tions of a bolt in case of Blaine's nomination were freely made. $^{1}$

A dinner attended by prominent Independents from $\mathrm{New}$ York, New England, New Jersey and Pennsylvania was given by the Brooklyn Young Men's Republican Club on Washington's Birthday. The speakers included Carl Schurz and President Seelye of Amherst College, and a letter from George W. Curtis was read. The tone of the meeting and of the resolutions adopted was that administrative reform should be the watchword of the campaign and that the nomination of a candidate bound to reform by his character, record and associations was indispensable to Republican success. A meeting was held the following day at which an organization was formed to be known as the "Conference Committee of Independent Republicans," to organize independent opinion throughout the country. This committee sent out circulars urging all Republicans to attend the primaries and vote for such a man as had been indicated in the resolutions. They neither endorsed nor condemned individuals, but their hostility to Blaine and, at first, to Arthur was clearly shown. ${ }^{2}$

The candidate most in favor with the Independents was Senator Edmunds of Vermont. He developed little strength, however, and as the time for the state conventions approached the efforts of the Independents were directed more and more toward defeating Blaine. In the New York state convention the Independents held the balance of power and the Arthur men combined with them to elect the Edmunds candidates for delegates at large. ${ }^{3}$

An unsuccessful attempt had been made at the meeting

${ }^{1}$ Nation, April 24; Schurz, Works, vol. iv, p. Ior.

${ }^{2}$ N. Y. papers, Feb. 23, 24; Ann. Cyc., 1884, p. 767; Nation, March 1o, April 13.

'Nation, May I, I884; Whitc, Autobiog., p. 201. 
of the Republican national committee in 1883 to change the basis of apportionment of delegates to the national convention so that it should have some relation to the voting strength of the party in the various states. The opportunity for congressional districts to elect their own delegates was secured by a provision that district delegates might be elected either by district conventions or by subdivisions of state conventions. State conventions were to be. held not less than thirty nor more than sixty days before the national convention. ${ }^{1}$

The convention assembled in Chicago on June 3. It was evident that Blaine was strong especially in the strongly Republican states. On the first test, however, the Blaine men lost. The national committee had proposed Powell Clayton of Arkansas a Blaine supporter, as temporary chairman. On motion of Lodge of Massachusetts the name of John R. Lynch, a negro delegate from Mississippi, who supported Arthur, was substituted by a vote of 424 to $384^{2}$ This caused rejoicing among the anti-Blaine forces but was not really decisive as the issue was not strictly an anti-Blaine one. The Logan delegates who were later to be thrown to Blaine voted for Lynch as they wished to conciliate the negro vote and also possibly because they wanted to show the Blaine leaders the importance of Illinois. ${ }^{3}$

After the first day the proceedings of the convention were unusually harmonious. The second day John B. Henderson was chosen permanent chairman without opposition. The committee on credentials reported, in all cases except two, in favor of the delegates seated by the national committee, and in these two, one from Kentucky and one from New York, the votes were divided between the contestants. ${ }^{4}$

${ }^{1}$ Stanwood, Presidency, p. 420.

2 Proceedings of the Convention, p. 6.

${ }^{3}$ Harper's Weekly, June I4.

"Proceedings, p. 50. 
A minority report was submitted from the committee on rules which provided that in future conventions each congressional district should have one delegate and one additional for each 10,000 votes or fraction thereof cast for the Republican electoral ticket at the previous election. After being attacked by the Southern delegates this was withdrawn and the majority report adopted without a roll call. ${ }^{1}$ The platform drafted by a committee of which McKinley of Ohio was chairman was adopted without discussion and without a roll call. ${ }^{2}$ A resolution was introduced by a delegate from Tennessee that it be the sense of the convention that "every member of it is bound in honor to support its nominee, whoever the nominee may be: and that no man should hold a seat here who is not ready to so agree." In support of the resolution George A. Knight, a Blaine delegate from California, made a direct thrust at Curtis and the Independents and showed the fear of a bolt when he said:

No honest Republican . . should dare to stand on the floor of this convention and vote down that resolution. There are already whisperings in the air, of men high in the Republican party, openly and avowedly declaring that they will not support one man if he be nominated by this Convention . . . and let all those, be they editors of newspapers or conducting great periodical journals, who refuse to support the nominee, let them be branded, that they not only come here and violate the implicit faith that was put in them, but the direct and honest conviction of this convention.

After Curtis and an Edmunds delegate from Massachusetts had attacked the resolution it was withdrawn. ${ }^{3}$

${ }^{3}$ Proceedings, p. 84.

2 Ibid., p. 91.

'Ibid., p. 37 et seq. 
By the evening session of the third day the convention was ready for the nomination. Brandegee of Connecticut nominated Hawley, urging his availability as the friend of Garfield and the friend of Grant, a candidate whom all elements could support with " nothing to be forgiven or forgotten." 1

In his speech nominating John Sherman, Foraker of Ohio declared that Ohio was a Republican state and would cast her electoral vote for the nominee of the convention. He called attention to the existing business depression and asserted that Sherman by reason of his experience and the "brilliancy of his common sense" was the candidate best fitted to allay the "distrust that disturbs the industrial interests of the country." 2

Logan was nominated by Cullom of Illinois. His honorable career in Congress and especially his war record and popularity with the veterans of the war was emphasized. ${ }^{3}$

Arthur was nominated by Townsend of Pennsylvania. Townsend pointed out that all factions were agreed that Arthur's adminstration had been an excellent one. He declared that to refuse him a renomination would be to furnish the Democrats, whom he characterized as "intelligent and tireless," with just grounds for attacking the sincerity of Republican desire for reform. Answering the charge that Arthur had been a machine politician, he said:

I have, sir, to prove that Mr. Arthur has not prostituted his office to the purposes of faction, but to point to the fact that Roscoe Conkling has given his whole influence against $\mathrm{Mr}$. Arthur; and that Mr. Thomas C. Platt, the man who resigned his office, and the man who could not sit in his seat in the Senate during Garfield's administration because Mr. Blaine was so

1 Proceedings, p. 100.

Ibid., p. 122.

'Ibid., p. 102. 
wicked as to persuade Mr. Garfield to nominate Mr. Robertson for Collector of the port of New York,-he is also opposed to Mr. Arthur. ${ }^{1}$

Arthur's nomination was seconded by Bingham of Pennsylvania, Lynch of Mississippi and Pinchbeck of Louisiana. Pinchbeck minimized the effect that Stalwart resentment would have on Arthur's strength. He also resented the charge that had been made that the votes of the negro delegates were for sale and urged all negroes to continue to support Arthur as an answer to the slander. ${ }^{2}$

West of Ohio nominated Blaine in an old-fashoned spread-eagle speech. He said that the solid South was against them and that the candidate must therefore be one who would appeal to all classes in the North. He dwelt on Blaine's long public career and closed with a prediction of his overwhelming success. ${ }^{3}$

Davis of Minnesota in seconding Blaine's nomination stressed the fact that he had always been regular, that although defeated in two conventions by narrow margins he had never sulked but had been instrumental in electing both his rivals. Grow of Pennsylvania also seconded the nomination. Most significant of the seconding speeches was that of Thomas C. Platt, who said: "I second this nomination, believing as I do, that his turn has come; believing as I do, that expediency and justice demand it; believing as I do, that the Republican people of the Republican states that must give the Republican majorities want him." 4

Edmunds' name was presented by ex-Governor Long of Massachusetts, who declared that the interests of the party

1 Proceedings, p. II2.

${ }^{2}$ Ibid., p. II9.

3 Ibid., p. I05.

4 Ibid., p. 108. 
were greater than the interests of any one man and that the interests of the country were greater than those of the party. He urged that the candidate must be one on whom all factions could unite. George W. Curtis' speech seconding Edmunds' nomination was as much a speech against Blaine as for Edmunds. It was a forceful exposition of the Independent point of view. He said :

Now, fellow-citizens, we approach a new contest, and we shall be tried by the candidate whom we submit to the people. I say we shall be tried by the candidate that we present. Do not forget that upon the man of our choice the eyes of the country will turn to see what it is that the Republican party honors and respects. It will turn to see what are the objects, what is the spirit, and what shall be the method of continued Republican administration. And, therefore, our candidate must be in himself a resplendent manifestation of Republican principle, $\mathrm{Re}$ publican character, and Republican purpose; a candidate who is in himself a triumphant victory.

We, gentlemen, have been long in power, and prolonged power breeds, as we have learned to our cost in the State of New York, and as you have learned, therefore, to your costprolonged power breeds dissensions within the party. The times are hard; and every man who feels poor, at once blames the administration of the government. The old issues are largely settled; and new men with new views are arising all around us; and vast questions, to which no man can be blind, solicit our present attention and sympathy.

This is the state of the country; this is the state of the party; and we are confronted with the Democratic party, very hungry, and as you may well believe, very thirsty; a party without a single definite principle; a party without any distinct national policy which it dares to present to the country; a party which fell from power as a conspiracy against human rights, and now attempts to sneak back to power as a conspiracy for plunder and spoils. Nevertheless, fellow-Republicans, we have learned, 
and many of you whom our hearts salute, have learned upon fields less peaceful than this, that our foe is not a foe to be despised. He will feel our lines to find our weakest point. He will search the work of this Convention with electric light. He will try us by our candidate. And therefore the man to whom we commit the banner-the banner that Abraham Lincoln bore-must be, like Abraham Lincoln, a knight indeed; and like the old knight, a " knight without fear and without reproach." He must be a statesman identified with every measure of the great Republican past, and a pioneer in every measure of its future of reform; and in himself the pledge that the party will not only put its face forward, but will set its foot forward; and a pledge also, that that mighty foot will trample and crush and utterly destroy whatever disgraces the public service, whatever defiles the Republican name, whatever defeats the just expectation of the country and of the Republican party ... 1

After the nominating speeches, in spite of the opposition of some of the Blaine men the convention adjourned. During the night numerous conferences were held among the anti-Blaine forces but no one opposition candidate could be agreed upon. ${ }^{2}$ Many of the Edmunds men were willing to support Arthur but the Edmunds votes were independent and could not be transferred in a body. A fusion movement had to be led by the Arthur men since they came first on the roll call, and they would support no other candidate. ${ }^{3}$ Mark Hanna and Theodore Roosevelt tried without success to start a boom for John Sherman." General W. T. Sherman had sent a telegram positively refusing to be a candidate or to serve if elected, ${ }^{5}$ but a boom started in spite of

1 Proceedings, p. 126.

${ }^{2}$ N. Y. Times, N. Y. Tribune, June 4, 5, 6; White, Autobiog., p. 203.

${ }^{3}$ Harper's Weekly, June I4.

${ }^{4}$ Rhodes, in Scribner's, Sept. I9II.

${ }^{5} N$. Y. Times, June 5 . 
this by Senator Hoar and G. W. Curtis was blocked by opposition to his wife's religion. ${ }^{1}$

The first ballot resulted about as had been predicted. Of Arthur's 278 votes, 196 came from the South, nine from the territories, thirty-one from New York, eleven from Pennsylvania, with the others scattered. With the exception of the solid Maine delegation and one vote from Massachusetts, Blaine received no votes from New England, but he had votes from every other state except Georgia, including solid delegations from California, Colorado, Nevada. Iowa, Oregon and West Virginia, and at least half the votes from Arkansas, Delaware, Indiana, Kansas, Maryland, Michigan, Minnesota, Nebraska, New Jersey, Pennsylvania and Texas. No important changes were made on the second or third ballots, Blaine gaining a few votes on each. After the third ballot an attempt to adjourn was frustrated by the Blaine men. Foraker of Ohio, amid great confusion in the galleries and on the floor, moved to nominate Blaine by acclamation, but the motion was ruled out of order. On the roll call for the fourth ballot Cullom of Illinois attempted to read a telegram from Logan withdrawing in favor of Blaine, but it was ruled out of order. Cullom then withdrew Logan's name and cast the vote of the state -Blaine thirty-four, Logan six, Arthur three. When Ohio was called Foraker " in the interest of the party" withdrew the name of John Sherman and cast the forty-six votes of the state for Blaine, insuring his nomination. After the vote had been announced, in accordance with the rules of the convention, the motion to make the nomination unanimous was put and carried without dissent. ${ }^{2}$ Curtis' biographer asserts that Curtis did not vote on the motion and

1 Rhodes, op. cit.

2 Proceedings, pp. 151-160. 
resisted strong pressure to take the platform and speak in favor of it. ${ }^{1}$

Blaine's nomination undoubtedly accorded with the freely expressed will of the great majority of the Republican party. It was won without the use of office-holders or official pressure of any kind. However distasteful to the Independent element, they had to admit that it was brought about fairly. ${ }^{2}$ If Blaine was an unworthy candidate the indictment must be brought against the rank and file of the Republican party.

G. W. Curtis is said to have remarked after the convention that Blaine's nomination was " a desperate and daring experiment." 3 It was an experiment in the sense that it was unusual for a party to nominate a man with so long a record as a political leader and public official. There was nothing of the dark horse or "impromptu statesman" 4 about Blaine. His strength and his weakness lay in the fact that his record was known. The voters could not plead the excuse of uncertainty as to what sort of a man the candidate was.

Superficially Blaine's nomination appeared to be a strong one. The votes of Sherman, his strongest rival in his own faction, and of Logan, one of the Stalwart leaders who had been his bitterest opponents in I880, had been voluntarily given to him. Platt, another of his former enemies, had done yecman work for him. ${ }^{5}$ The two strongest factions of the party numerically appeared united. The Independents were to be reckoned with, however, and events proved

${ }^{1}$ Cary, Curtis, p. 287.

${ }^{2} N$. Y. Times, June 7; Nation, June 12; Roosevelt, Autobiography, p. 96.

${ }^{3}$ N. Y. Tribune, June 8.

${ }^{4}$ Hamilton, Blaine, p. 629 , letter of Evarts.

${ }^{5}$ Ibid., p. 627 , letter of W. W. Phelps. 
that it was more important that the nomination be agreeable to them than that it be agreeable to either of the other two factions. The Half-Breeds had not been enthusiastic about the nomination in 1876 , that of 1880 had been unsatisfactory to the Stalwarts, yet the sense of party loyalty had been strong enough to prevent a break. In I884 the Independents were dissatisfied and their defection and the defeat of the party resulted.

Logan received the nomination for Vice-President without a contest. A motion was passed almost unanimously to nominate him by acclamation, but for the sake of regularity the roll was called and he secured the votes of all except the New York delegation. ${ }^{1}$

Logan was a politician of the old school. He entered politics in Illinois in the early fifties as a disciple of Stephen A. Douglas and, after serving in the state legislature and two terms in Congress as a Democrat, he organized a regiment in Illinois at the outbreak of the war, and served throughout the war with credit, rising to the rank of majorgeneral. In I 866 he was elected to Congress as a Republican, and after two terms was elected Senator in 1870 and again in 1878 . In Congress he was noted more for his strong partisanship than for his statesmanlike qualities. He aligned himself with the radicals on the reconstruction question and his principal speeches in the House and Senate were attacks on the ex-Confederates. He was a loyal supporter of Grant and with the help of the federal patronage made himself supreme in the Republican councils of Illinois. He was active in G. A. R. affairs and had served three terms as commander-in-chief of the organization. His popularity with the veterans was increased by his warm advocacy in Congress of pension bills both general and private. His education had been fragmentary and his gram-

1 Proseedings, p. 168. 
mar was often a source of amusement to his opponents. He owed his political strength to hard work, willingness to serve his friends, and skilful manipulation of the patronage and the political machinery. Although a Stalwart, a boss, a politician who knew no other than machine methods, he had always shown more regard for public opinion than many of his associates and had willingly modified his course when he saw that it was likely to be unpopular with the more thoughtful elements of the community. His advocacy of the Pendleton civil-service act is a case in point. He had favored greenbacks but had voted for the resumption act and was considered "sound" on financial questions in I884. His integrity was unquestioned. His nomination, however, added nothing to the strength of the ticket in the eyes of the Independents. ${ }^{1}$

1 Dawson, Life and Services of Gen. John A. Logan, passim; Rhodes, $o p$. cit., vol. vi, p. 224, vol. vii, pp. 53, 58; N. Y. Tribune, June 7, 1884 . 


\section{CHAPTER IX}

\section{The Democratic Nomination}

With the prospects of a Democratic victory brighter in I 884 than they had been in years, a large number of Democrats were in a receptive mood for a nomination. Favorite sons flourished. There were few among them, however, who were of what was generally considered to be Presidential caliber. The long exclusion of the Democrats from any share in the executive offices had limited the number of their leaders of national prominence. Among their leaders in Congress a large number of the ablest were unavailable because of their active sympathy with the South during the war. The lack of unanimity within the party on the tariff question made inadvisable the nomination of any of the men who had taken an extreme stand on either side of that issue. Thus, advocacy of free trade barred Carlisle of Kentucky and Morrison of Illinois, while Randall of Pennsylvania was too much of a protectionist to suit the West and South.

There was a feeling in the West that, after twenty years of failure with eastern candidates, it was time that the West should be recognized. ${ }^{1}$ Indiana, one of the doubtful states which it was especially important to carry, had two candidates, Joseph E. McDonald and Thomas A. Hendricks. Both had served in the House before the war and in the Senate since. Both were men of ability and there had been a long rivalry between them for leadership of the party in

${ }^{1}$ Vide Proc. Nat. Dem. Conv., I884, p. 106. 
Indiana. ${ }^{1}$ McDonald, who had been a workingman himself, was thought to be strong with labor. He was suspected, however, of leanings toward free trade. ${ }^{2}$ Hendricks had opposed McDonald in 1880 and prevented his getting the united support of the Indiana delegation, but in 1884 Indiana sent a solid delegation for McDonald to the convention and Hendricks made the speech nominating him. There was a rumor current before the convention, which events seemed to substantiate, that McDonald's candidacy was a blind and that Hendricks would be brought forward at the proper time if that time came.

Hendricks was one of the Democratic old guard. As a member of the House he had voted for the Kansas-Nebraska bill and been defeated for re-election. He was elected to the Senate in 1863 and although he had skated at times on rather thin ice in his opposition to the administration, ${ }^{3}$ no charge of disloyalty to the Union could be made against him. He had favored greenbacks and his ideas on most financial questions were much more acceptable in Indiana than in the East. ${ }^{4}$ Bigelow's estimate of Hendricks in his Life of Tilden, that he "might have been a statesman if he had been less of a demagogue," seems to be a fair one. ${ }^{5} \mathrm{He}$ had been one of the leading candidates for the nomination for the Presidency in I868 and had accepted second place in 1876 . Although he had lost ground to McDonald in Indiana he was talked of both as a candidate for President and as a running mate for Tilden again in case the old ticket should be revived.

1 McClure, Lives of Cleveland and Hendricks, p. 194.

${ }^{2} N$. Y. World, June 13, 1884 .

${ }^{3}$ N. Y. Tribune, July I2, 1884.

${ }^{4}$ Rhodes, Hist. of U. S., vol. vii, p. 213; Woodburn, Political Parties and Party Problems, p. 105.

${ }^{5}$ Vol. i, p. 205. 
Ohio, the other middle-western state which the Democrats had hopes of carrying, also had several candidates, among them Allan G. Thurman, Oliver Payn and George W. Hoadly. Thurman was another old-time Democrat. $\mathrm{He}$ had served in Congress before the war, had been narrowly defeated by Hayes for governor of Ohio in 1867 , had been chief judge of the Supreme Court of Ohio and had been in the Senate from I868 to I88o. Payn, who had been elected to succeed Pendleton in the Senate, was spoken of favorably in the East, but his connection with the Standard Oil Company and his lack of political experience made him unavailable. ${ }^{1}$ Hoadly was one of the Republicans who had joined the Liberal movement of 1872 and then gone back to the Democrats. He was a lawyer of national prominence and had been elected governor of Ohio in 1883. None of the Ohio candidates was strong enough to secure more than a minority of the delegates from his own state. The fact that the Congressional election was held in Ohio in October also was against the selection of any candidate from that state, as the Democrats were not certain of carrying it and feared the psychological effect of failing to carry the home state of their candidate.

There was a great deal of talk in the early part of the canvass about the "old ticket" - Tilden and Hendricks. Most Democrats believed that Tilden had been deliberately cheated out of the Presidency in 1876 and the "fraud" issue had been prominent ever since in every Democratic gathering. Tilden received many letters from prominent Democrats urging him to accept the nomination. ${ }^{2}$ Several state conventions instructed their delegates to support him. It was generally believed, however, that Tilden was phys-

${ }^{1} N . Y$. World, July $13,1884$.

${ }^{2}$ Bigelow, Life of Tilden, vol. ii, pp. 404-410. 
ically unable to make the canvass and that his boom was a strategic move to line up delegates who might be transferred later to the man whom the leaders decided on. ${ }^{1}$ On June 12 a letter from Tilden to Daniel Manning, chairman of the New York state Democratic committee, was published in which he definitely declined to accept a nomination on account of old age and poor health. ${ }^{2}$ Some of his supporters did not even then give up the idea that he might still be a candidate and it was not until after Tilden had telegraphed the convention that he would refuse even a unanimous nomination that the project was abandoned. ${ }^{3}$

One of the most prominent candidates and one best fitted by character and training was Thomas F. Bayard of Delaware. He had been in the Senate since 1869 and had played a prominent and honorable part there. $\mathrm{He}$ was strong with the more conservative element in his party and was well thought of by the Independent Republicans. ${ }^{4} \mathrm{He}$ had received votes in the last three conventions. There were several things, however, that counted against Bayard with the practical politicians. He came from a small state. $\mathrm{He}$ was, in theory at least, a free-trader, being one of the charter members of the New York Free Trade League, ${ }^{5}$ and was unpopular with protectionists. ${ }^{\circ}$ Above all, he had at the outbreak of the Civil War made a speech against the war and in favor of allowing the South to secede peaceably, ${ }^{7}$ which, whether justly or not, was sure to be brought up against him and to hurt his chances if he were nominated.

${ }^{1}$ Nation, May 29, N. Y. Tribune, June 12.

2 N. Y. papers, June 12.

${ }^{3}$ N. Y. Sur, July 8; Bigelow, Letters of Tilden, p. 655.

-Schurz, Works, vol. iv, p. 205.

${ }^{5}$ Wheeler, Sixty Years, p. 150.

- N. Y. World, June 14, 24, 1884.

${ }^{7}$ Nation, June 19; N. Y. Times, June ro, 1884 . 
At the opposite pole of the party was Benjamin Butler, who received in May the nominations of the Greenback and Anti-Monopoly parties. He was in close touch with the Tammany leaders in New York and threatened to make trouble at the convention. ${ }^{1}$ Charles A. Dana, the editor of the New York Sun, after having shown the weaknesses of all possible Democratic candidates except himself and Butler, in the days before the convention began to speak favorably of Butler. ${ }^{2}$

Roswell P. Flower of New York was mentioned as a candidate but was not taken seriously. He received some Tammany support as the man most likely to defeat Cleveland. Flower had inherited a large fortune and was a prominent figure in financial and social circles of New York, famous for his contributions to charity. He had been in Congress and was generally looked upon as a rich man amusing himself in politics. ${ }^{3}$

In 1880 Grover Cleveland was an unknown lawyer in Buffalo, New York. He had taken part in local politics as a Democrat, serving as assistant district attorney and later as sheriff of Erie county and he had been defeated for district attorney. In 1880 he was nominated for mayor of Buffalo, received the support of independent voters and was elected by a majority of 3500 . As mayor he proved to be an able, hard-working, conscientious and fearless executive. His appointments were good; he vetoed several extravagant appropriations of the board of aldermen and in general conducted the affairs of the city on business lines. In 1882 he was nominated for governor and, aided by the support of the Independents and the general revolt against

${ }^{1}$ Schurz, Works, vol. iv, p. 213.

${ }^{2} N$. Y. Sun, April-June I884; N. Y. Times, June I5, 16.

${ }^{3}$ Alexander, op. cit., vol. iii, p. 488; Nation, Jan. 24, I884. 
the Republican machine, was elected by the unprecedented plurality of $192,000 .^{1}$

Cleveland, as governor, lived up to the expectations of his supporters. His appointments were uniformly good. His attitude in the passage and administration of the civil service reform law gained him the approval of civil service reformers. ${ }^{2}$ He kept close watch over the legislature, which was Democratic during his first year and Republican during the second. He made free use of his veto power, showing in his vetoes a disregard for political advantage, an interest in the popular welfare and a high sense of the duty and obligations of the state and its officials. Several bills were vetoed because they were poorly drawn and vague, others, notably the five-cent-fare bill, because they were not in accord with the letter or spirit of contracts voluntarily entered into by the state. Many appropriations were refused as being unnecessary or illegal. ${ }^{3} \mathrm{He}$ was also vigorous in his advocacy of legislation which he believed to be necessary, so much so that he was accused of unconstitutional interference with the legislature. ${ }^{4}$ Among the more important bills passed during his term were the civil service bill, the bill creating a bureau of labor and the Roosevelt reform bills for the city of New York.

Cleveland was not a brilliant man. His education and his experience had been limited. He was not a polished speaker. He lacked most of the qualities usually associated with great leaders. "He represented the practical, every-

1 Parker, Recollections of Grover Cleveland, pp. 20-55; Hanford, Early Life and Public Services of Grover Cleveland, passim; Dorsheimer, Life of Cleveland, passim; Nation, Sept. 28, I882.

${ }^{2}$ Nation, June 19, July 10, 17, 24, 1884; N. Y. Eve'g. Post, Oct. 27, I884; N. Y. Times, July $2,7,24,1884$.

3 Public Papers of Grover Cleveland, 1883, 1884, passim.

${ }^{4}$ N. Y. Tribune, Jan. 24, March 5, I884. 
day, usual citizen of moderate means and no very marked ambitions, a combination of the business man and the unimportant professional person, blunt, hard-headed, brusque, and unimaginative." ${ }^{1} \mathrm{He}$ was absolutely honest and straightforward, had a great capacity for hard work and a real desire to serve the people. He was deliberate in all his actions and not easily swerved from his purpose. He was conservative rather than progressive on most questions, especially economic ones. His humble-mindedness and his sense of responsibility are shown in a personal letter written to his brother on the night of his election as governor.

I will tell you first of all others, the policy I intend to adopt, and that is, to make the matter a business engagement between the people of the state and myself, in which the obligation on my side is to perform the duties assigned me with an eye single to the interests of my employers. I shall have no ideas of reelection or any higher political preferment in my head, but be very thankful and happy if I can well serve one term, as the people's Governor. ${ }^{2}$

Cleveland had always been a party man but not merely a party man. His ideas as to the function of parties were well expressed in a speech at a Democratic gathering in New York city in December, I882, shortly after his election as governor.

I am quite certain, too, that the late demonstration did not spring from any pre-existing love for the rarty which was called to power, nor did the people place the affairs of state in our hands to be by them forgotten. They voted for themselves and in their own interests. If we retain their confidence we must deserve it, and we may be sure they will call on us to give an account of our stewardship. We shall utterly fail to

${ }^{1}$ Peck, Twenty Years, p. 29.

${ }^{2}$ Parker, Writings of Grover Cleveland, p. 535. 
read aright the signs of the times if we are not fully convinced that parties are but the instruments through which the people work their will and that when they become less or more the people desert or destroy them. The vanquished have lately learned these things and the victors will act wisely if they profit by the lesson. ${ }^{1}$

There was nothing in his conduct as governor to indicate that these were not his real ideas. The charge that he was a machine politician and had used his office to build up a personal organization for himself, ${ }^{2}$ had little foundation. ${ }^{3}$ While the Republicans were complaining of his partisan activities the Democratic New York Sun was condemning him for "his plan of governing without reference to the party that put him in power." 4 The principle factions in the Democratic party of the state were Tammany and antiTammany. Tammany had a strong organization in New York city and a few scattered supporters upstate. Their opponents were the County Democracy in the city and the group upstate of which Daniel Manning of Albany was the leader. Manning, the owner of the Albany Argus, had been active in politics for several years and his great political shrewdness and his ability to manage men had won him a commanding position in the party. He had been a protégé of Tilden, had supported Robinson, and now turned to Cleveland as the coming Democrat. ${ }^{5}$ He had been active in bringing about Cleveland's nomination and election and was one of his chief advisers. When Cleveland found it necessary to choose between the factions, he chose the anti-

1 Parker, Writings of Grover Cleveland, p. 242.

${ }^{2} N$. Y. Tribune, July I8, Oct. 21, 23, I884.

${ }^{3}$ Wheeler, op. cit., p. 415; White, Autobiog., pp. 199, 207.

"July 21 , I 884 .

${ }^{5}$ Alexander, op. cit., vol. iii, p. 419; Hudson, op. cit., p. $: 53$. 
Tammany one. Hubert O. Thompson, the leader of the County Democracy, was commissioner of public works of New York city. A bill, called the Tenure of Office bill, which changed the term of several New York city officials and incidentally legislated Thompson out of office, passed the legislature and was vetoed by Cleveland on the ground that it was poorly drawn and would not effect its avowed purpose. ${ }^{1}$ Tammany made the charge, which the Republicans took up, that Cleveland had vetoed the bill in order to protect his friend Thompson, ${ }^{2}$ but the author of the bill later admitted that it had been amended until it was, as Cleveland had said, a piece of "defective and shabby legislation." 3

Tammany's real reason for opposing Cleveland was, then, that he had sided with their opponents within the party and refused to give them what they considered to be their share of the spoils. The reason that they gave, however, was that he could not carry New York state, and they cited as proof of this the election of 1883 in which Cleveland's candidate for secretary of State had been defeated. The governor was said to have gained the ill-will of the antimonopolists, the laboring men, the Roman Catholics and the Irish. ${ }^{4}$

There was undoubtedly some opposition to Cleveland on the part of labor, as he had vetoed several bills in which the workingmen were interested. Cleveland's views as to the rights of labor were really enlightened for his time. He believed that the welfare of the workingman was a proper subject for legislation, and that labor should be given its full and exact rights under the law. He was just as insis-

${ }^{1}$ Public Papers of Cleveland, I884, p. 164.

${ }^{2} N$. Y. Tribune, Oct. 19, 2I, 1884.

${ }^{3}$ N. Y. Eve'g. Post, July io, 1884.

" Proceedings of Conv., pp. I20-130, I34-139, I69. 
tent that the rights of capital and all vested interests should be protected. The trouble was that under the current political and economic philosophy the rights of capital had developed to such an extent that the growing needs and aspirations of labor were bound to conflict with them. Cleveland had vetoed a law which reduced the rate of fare on the New York city elevated railways to five cents at all hours of the day, on the ground that it was an impairment of the contract existing in the charter to the company and that no investigation had taken place, as required by the charter, to show excessive remuneration. ${ }^{1} \mathrm{He}$ had vetoed the " mechanics' lien" bill on the ground that it was poorly drawn and would increase lawyers' fees without any real benefit to mechanics. ${ }^{2} \mathrm{He}$ had vetoed a bill to limit the hours of work of car drivers and conductors to twelve hours a day on the ground that it was class legislation and would be ineffective. ${ }^{3}$ On the other hand, laws had been passed and approved by him creating a bureau of labor statistics, prohibiting the manufacture of cigars in tenement houses, abolishing the system of contract prison labor, prohibiting the manufacture of wool hats in prisons, and prohibiting child labor in institutions. ${ }^{4}$ Walter N. Thayer, president of the New York State Trades Assembly, wrote a letter endorsing Cleveland and declaring that his record entitled him to the support of all workingmen. ${ }^{5}$

It was charged that Cleveland had shown undue regard for corporations in his appointments, especially to the railroad commission and to the office of superintendent of public works, as well as by his veto of the five-cent-fare

${ }^{1}$ Public Papers, 1884, p. 40.

${ }^{2}$ Ibid., p. 213.

IIbid., p. 197.

${ }^{4}$ Democratic Campaign Textbook, I884, p. 22 et seq.; N. Y. Times, July 2, 15; Nation, July 10, 1884 .

${ }^{5} N$. Y. Times, July 22. 
bill. $^{1}$ These appointments had, however, gained general approval. In his letter accepting the nomination for governor Cleveland gave a clear statement of his ideas as to the rights of corporations and their necessary limitations. "Acting within their legitimate sphere, they should be protected; but when ... they oppress the people, the same authority which created should restrain them and protect the rights of the citizens." ${ }^{2}$ Cleveland's acts as governor were quite in harmony with this statement. In his message of 1884 he said: "It is a grave question whether the formation of these artificial bodies ought not to be checked or better regulated and in some way supervised." At the same time he recommended a law providing publicity for all corporation accounts for the protection of the stockholders and the investing public. ${ }^{3}$ During his term he vetoed a large number of bills granting special privileges to individual corporations. ${ }^{4}$

Roman Catholic opposition to Cleveland, so far as it existed at all, was based on his veto of a bill appropriating state funds for the Catholic Protectory in New York city. His reasons for this veto were that it was a bad precedent to grant funds to a sectarian institution and that the Protectory was properly a charge against the city of New York alone. ${ }^{5}$ James Shanahan, superintendent of public works, John A. McCall, superintendent of insurance, two prominent Catholics appointed by Cleveland, together with ex-Senator Kernan, hurried to the National convention of I884 to put down the rumor that Cleveland was antiCatholic. ${ }^{\circ}$

1 Proceedings, p. 123.

${ }^{2}$ Dem. Camp. Textbook, p. 22.

3 Public Papers, I884, p. 38.

- Dem. Camp. Textbook, p. 22 et seq.

${ }^{5}$ Public Papers, I883, p. II4.

- Hudson, op. cit., p. 165. 
Interest centered in the New York state Democratic convention, for it was felt that Cleveland's success at Chicago depended largely on his ability to control New York. Tammany demanded equal representation with the County Democracy and received it without opposition. The convention was so evenly divided that Cleveland's friends took care to avoid any test vote and thereby got the credit for controlling the convention. No attempt was made to pledge the delegates to any candidate but a resolution was adopted instructing the delegation to vote as a unit, as the majority might direct, on all matters. ${ }^{1}$ Cleveland's margin of control was very slight and was not definitely secured until the national convention met at Chicago. ${ }^{2}$

There had been considerable gossip as to what effect Tilden's withdrawal would have on Cleveland's chances, the general opinion being that it would help them. Finally Tilden came out definitely for Cleveland. Other prominent Democrats of the state, among them Seymour, Kernan, Hewitt and Dorsheimer, endorsed Cleveland. ${ }^{3}$ Tammany's opposition, however, was not lessened. The Sun adopted a tone more and more hostile to Cleveland, declaring that he might be strong with those who were not Democrats but that with Democrats he was weak. It hinted at and justified a Tammany bolt in case he was nominated. ${ }^{4}$ At the Tammany Fourth-of-July celebration on the eve of the convention opposition to Cleveland was rife. John Kelly's speech making thinly-veiled attacks on him was warmly applauded. Cleveland's name was hissed and Butler's greeted with cheers. ${ }^{5}$

${ }^{1}$ N. Y. World, Times, June 19, 20; Nation, June 19, 26; Ann. Cyc I884, p. 584; Breen, Thirty Years, p. 690.

${ }^{2}$ Hudson, op. cit., p. 166

${ }^{3} N$. Y. World, June 13 , I8, July 5 ; Nation, July 3 .

${ }^{4}$ June 30 , July $3,4,6,7$.

${ }^{5} N$. Y. Times, July 7 . 
Cleveland had received many Republican votes in his campaigns for both mayor and governor, and his record had strengthened his hold on the Independents. The nomination of Blaine improved Cleveland's chances as it was evident that a large number of Independents would not support Blaine but would support such a Democrat as Cleveland. Curtis declared after the Republican convention that Cleveland, if nominated, would get most of the Independent votes and would carry New York. ${ }^{1}$ On June 7, the Massachusetts Reform Club voted to repudiate the Republican nominations and to request independent voters throughout the country to join them in trying to secure the nomination by the Democrats of such a man as they could support, and failing in that, to call a convention to make independent nominations. ${ }^{2}$ Conferences of Independents were held in Boston on June 13 , and in New York on June I7, which adopted resolutions condemning the Republican nominations and calling on the Democrats to make nominations which they could support. No names were mentioned but it was generally understood that they would support either Bayard or Cleveland if nominated. ${ }^{3}$ Harper's Weekly came out for Cleveland and declared that he should, and probably would, receive Independent support if nominated. ${ }^{4}$ Schurz wrote to Bayard, June 28 , saying that the Independents would support either Bayard or Cleveland, that either could carry New York, but that he himself preferred Bayard because of his wider experience. He warned Bayard not to allow the rivalry between himself and Cleveland to permit the nomination of some one not acceptable to the Independents. The warning was repeated in another

${ }^{1}$ N. Y. World, June 8, I884.

${ }^{3}$ Nation, June $\mathbf{1} 2$.

${ }^{3} N$. Y. Times, June 13, 14, 18; Nation, June 19; $A n n . C y c$., 1884, p. 770 .

${ }^{4}$ June 24. 
letter dated July 2 , in which Schurz said that Tammany and Butler were using Bayard to beat Cleveland and urged Bayard not to be a Tammany tool but to cooperate with Cleveland's friends. ${ }^{1}$ A message to Schurz from Blaine in a letter from John B. Henderson showed that Blaine fully appreciated the situation. ${ }^{2}$

The Democratic convention assembled in Chicago on Iuly 8. The call for the convention, contrary to former practice, invited the Democrats of each organized territory and of the District of Columbia to send two delegates. These territorial delegates were given votes by action of the convention. $^{3}$ Richard B. Hubbard of Texas was elected temporary chairman and William F. Vilas of Wisconsin permanent chairman of the convention. The committee on credentials had but one contest to decide, that of the twelfth Massachusetts district, and it recommended that the votes be divided between the contestants. ${ }^{4}$

The anti-Cleveland forces first showed their hand in an attempt to abolish the unit rule. To the motion that the rules of the convention of I88o be adopted, Grady of New York proposed an amendment that when the vote of a state was challenged the secretary should call the names of the individual delegates and their individual votes should be recorded as the vote of the state. This precipitated a long and acrimonious debate during which the galleries had to be frequently called to order for a too noisy display of their feelings. The main point made against the amendment was that the New York delegates had been elected by the state convention and not by congressional districts and that it would be contrary to all Democratic precedents for the

${ }^{1}$ Schurz, Works, vol. iv, pp. 205 et seq.

'Ibid., p. 212.

3 Proceedings, p. 53.

${ }^{4}$ Ibid., p. 52. 
national convention to overrule the expressed will of a state. The amendment was finally lost by a vote of 332 to 463 and the rules of the convention of 1880 , with the addition that no state be allowed to change its vote until the roll call had been completed, were adopted. ${ }^{1}$ New York was the only state that had instructed its delegation to vote as a unit. The minority of the New York delegation made various efforts to have the vote of the state recorded as cast by individuals. ${ }^{2}$

The main excitement outside of the struggle over the unit rule and the nomination itself was furnished by Benjamin Butler. Butler was a member of the committee on resolutions and took no part in the preliminary proceedings of the convention. His candidacy had received a set-back by his failure to unite the Massachusetts delegation in his own support and his name was not presented to the convention. With his chances for a nomination appearing hopeless he evidently determined to make all the trouble that he could for the Democrats and then appear before the country as a man who had sacrificed his chances for a nomination to his principles. When the platform was submitted by the committee of which Morrison of Illinois was chairman, Butler offered a set of resolutions on the tariff as a substitute for those of the majority and proposed the addition of several other planks to the platform.

His tariff project declared that it was the duty and aim of the party to depend on customs duties for all revenue. The duties should be so levied that the burden would fall on luxuries, allowing necessities to come in free. They should be such as to promote American enterprise and foster and cherish American workingmen while preventing monopo-

1 Proceedings, p. 9 et seq.

${ }^{2}$ Ibid., p. 223. 
lies. ${ }^{1}$ As to just how this was to be accomplished there was no suggestion.

Butler's other proposals included some that were praiseworthy and have since come to be recognized as sound social policy, while others, particularly his civil service plank, ${ }^{2}$ were most reactionary and unenlightened. He demanded for labor the right to organize for its own protection and to receive a just share of the profits of its own production. He opposed the importation of contract labor and the use of convict labor. He declared that the public lands should be held by the many and not by the few and particularly not by "the alien aristocracy of Europe." Corporations were to be regulated by the same power that created them and Congress was to prevent discrimination in interstate commerce. As to the currency, he declared that "the legal tender note has become the fixed currency of the United States . . . . neither policy nor duty calls for any meddling with it." 3 His whole platform, despite its good features, had more the ring of a demagogic appeal for votes than of a reasoned program of definite action.

Butler defended his proposals in a long speech in which he brutally laid bare the attempt of the majority to avoid the tariff issue and threatened the party with the loss of the votes of his supporters if it did not accept his ideas. He said, in part :

I come here as no mendicant, no beggar. I come here representing more than $1,500,000$ laboring men. I have brought their condition before this 'Convention. I demand, not that you should give them anything, but when you are taking from the people you take it only where it will hurt them least. Is that

1 Proceedings, p. 203.

2 Vide supra, p. Ior.

3 Ibid., pp. 203-206. 
an unreasonable demand? Do you think that you can get along without them? I do not. And therefore I have brought them here as your allies to receive them, and they will see me go away sorrowing if you will not receive them.

I object to the tariff plank of your platform adopted by your Committee, for it took them 36 hours to frame it ; and if it took those able gentlemen that time to frame it and get it in form there must be some reason for it. . . . The difficulty was that there was a radical difference between us-a difference of principle. The very able Chairman of the Committee, Col. Morrison, for whom I have the very highest respect, believes that there should be no such thing as protection of American labor by revenue taxation-indeed I think he believes that it cannot be done-and I believe that there should be such protection, and such fostering, and such cherishing. He could not yield his convictions; I could not yield mine; and therefore, our associates upon the Committee had to spend all that time to say something which would mean one thing one way and another thing another. And now read that platform. Read that tariff plank and then see if you can find out exactly what it does mean.

It does not mean protection. If it did Col. Morrison is too honest a man to bring it here. And yet it is twisted so that it is supposed that it might mean protection. Democrats in the Convention, you passed a tariff plank in $1876-$ a tariff for revenue only-only for revenue-and you had a statesman that could carry a very poor platform on his back and yet win. In 1880 you had a tariff for revenue only. It broke the back of the most gallant soldier of the country and you lost. And now you have got a tariff for public purposes exclusively. What is the difference? "Exclusively" means " only"; " only" means "exclusively". Think it over. I am here about no boys' play. The success of this campaign, in my judgment, before God, depends upon the question this night to be settled here and now. If you will not say to the workingmen of New York, New Jersey, Connecticut, New Hampshire and Massachusetts that 
you mean protection to their interests when you can, and say it with no uncertain sound, God help you, for I cannot. . . . 1

After Butler's speech, Converse of Ohio and Watterson of Kentucky, representing the two extremes of the party on the tariff question, spoke in defense of the platform. Both declared that there was a necessity for compromise on minor matters and that reform in government was the one big issue before the party. ${ }^{2}$ The motion to substitute Butler's tariff plank was then defeated by a vote of $96 \mathrm{r} / 2$ to $72 \mathrm{I} / 2$, the votes for Butler's plank coming twenty and onehalf from Massachusetts, twelve from Michigan, twelve from California, eleven from Pennsylvania, eight from Indiana, seven from Illinois and the others scattered. After another motion to add the rest of Butler's proposals had been defeated, the platform as reported by the majority was adopted without a roll call. ${ }^{3}$

In his speech on taking the chair as temporary chairman, Hubbard of Texas struck the three notes that were to be sounded again and again in the nominating speeches. These were the "fraud of I876," the dissatisfaction within the Republican party with Blaine's nomination and the necessity for forgetting old sectional animosities between the North and South. ${ }^{4}$

Extravagant praise of Tilden and a desire to be able to support him again were expressed by the backers of practically every candidate. Even Tammany, now that there was no chance of his nomination, declared their undying devotion to him and their desire to have him again at the head of the ticket. ${ }^{5}$ The convention passed a resolution express-

${ }^{1}$ Proceedings, pp. 206-210.

Ibid., pp. 21 I, 213.

${ }^{3}$ Ibid., pp. 218, 220.

"Ibid., p. 5.

'Ibid., p. I34. 
ing regret at his refusal to accept a nomination and declaring that "though fraud, force, and violence deprived Samuel J. Tilden and Thomas A. Hendricks of the offices conferred upon them by the Democratic party of the Union in 1876, they yet live, and ever will, first in the hearts of the Democrats of the country." 1 The platform also contained a paragraph bemoaning the fact that Tilden was no longer able to lead and announcing the devotion of the party to the principle for which he stood. ${ }^{2}$

Hendricks nominated McDonald in a speech which was devoted to the claims of Indiana to the nomination, and was therefore as good a speech for himself as for McDonald. Carlisle was nominated by James A. McKenzie of Kentucky, who urged that the fact that Carlisle came from the "wrong side of the Ohio river" was an outworn plea and contrasted Carlisle's record with Blaine's. Thurman was nominated by Breckenbridge of California, and Hoadly by Powell of Ohio. ${ }^{3}$

In nominating Bayard, Gray of Delaware emphasized the dissatisfaction with Blaine and the contrast in character offered by Blaine and Bayard. ${ }^{4}$ Youmans of South Carolina, in seconding Bayard's nomination, warned against underestimating Blaine's strength, saying that " if it is true .. . that he is buoyant by putrefaction, he is buoyant still," and urging that " in opposition to the knight of the soiled plume" they place "the knight without fault and without reproach.'

The figure that was in the background during all the nominating speeches, however, was that of Cleveland.

1 Proceedings, p. 187.

${ }^{2}$ Stanwood, Presidency, p. 439.

3 Proceedings, pp. 99, II I, 107, 160.

${ }^{4}$ Ibid., p. 97.

${ }^{5}$ Ibid., p. I72. 
Many of the speeches, nominally in support of another candidate, were attacks on Cleveland. Cummings of Massachusetts in seconding Bayard's nomination said: "Thrust upon us this man who has rent the garment of success in New York and we lose the state. . . . If you try to put the torn garment of New York on the candidate of the Democratic party you have lost the country and you have banished the labor vote." In seconding Thurman's nomination Ward of Ohio said: "We bring to you no callow politician. We bring to you no man who has to tarry at Jericho until his beard has grown." In nominating Randall, Wallace of Pennsylvania declared that the nominee must be a man "grounded in the faith and tried in the stern crucible of his party's service," and urged the convention not to trust " the delusive promises of our erstwhile bitter foes." Abbett of New Jersey in seconding Randall's nomination said that Hancock had been defeated in 1880 on the tariff in New York and that the same fate was awaiting Cleveland if nominated. ${ }^{1}$

Cleveland was nominated by Lockwood of New York, who, emphasizing the idea that Cleveland represented the new element of the party, said:

No man has greater respect or more veneration for the honored names which have been presented to the convention than myself; but, gentlemen, the world is moving, and moving rapidly. From the North and the South new men-men who have acted but little in politics-are coming to the front, and to-day there are hundreds and thousands of young men in this country, men who are to cast their first vote, men who are independent in politics, and they are looking to this Convention praying silently that there shall be no mistake made here. ${ }^{2}$

1 Proceedings, pp. 169, 162, 167.

${ }^{2}$ Ibid., p. II7. 
Carter Harrison of Illinois seconded Cleveland's nomination, declaring him to be the logical heir to Tilden's reform platform and minimizing the opposition to him as mere partisan spite. ${ }^{1}$

Tammany then brought forward their heavy artillery. Grady declared that he would be glad to second Cleveland's nomination were it not for the fact that he could not carry New York. He said that the labor element and the antimonopoly element were solidly opposed to him, and justly so, and deprecated the idea of alienating a large part of the Democratic party for the sake of catching a few Republican votes. Grady's speech was interrupted by hisses and cries of "Why don't you speak for Blaine?" The point of order was made that he had no right to speak unless making or seconding a nomination, but he was allowed to continue by unanimous consent given at the request of Daniel Manning, chairman of the New York delegation. ${ }^{2}$ Grady was followed by Bourke Cockran, who with perfervid oratory bitterly attacked Cleveland in a speech which purported to be one seconding the nomination of Thurman. He said:

I am too warm a friend of his to desire his promotion to an office for which I do not believe he has the mental qualifications, and where too it is designed, that he shall be the puppet of the gentlemen who have managed to capture the majority of the New York delegation. . . . We have been told that the mantle of Tilden has fallen upon the shoulders of Cleveland. Gentlemen, when the mantle that fits the shoulders of a giant falls on those of a dwarf, the result is disastrous to the dwarf. The shoulders of Mr. Cleveland cannot uphold that ample mantle. ${ }^{3}$

The Tammany orators were followed by Apgar of New

1 Proceedings, p. 120.

${ }^{2}$ Ibid., p. 124 et seq.

${ }^{3}$ Ibid., pp. I34, I39. 
York, who said that there were 100,000 independent voters in New York state to whom the Democrats must appeal if they wished to carry the state, and that these voters all wanted Cleveland. The same idea of Cleveland's strength with independents was emphasized by Kent of New Hampshire and Doolittle of Wisconsin. Cleveland's nomination was also seconded by Waller of Connecticut, Ross of Arkansas, and Jones of Minnesota, in behalf of the delegations of their respective states. After a long speech by Mansur of Missouri seconding Thurman, another member of the Missouri delegation announced that in behalf of a majority of the delegation he wished to second the nomination of Cleveland. ${ }^{1}$ The strongest speech for Cleveland was that made by Gen. Bragg of Wisconsin, as follows:

Grim and gray personally, fighting the battles of the Democratic party, I stand to-day to voice the sentiment of the young men of my state when I speak for Governor Cleveland. His name is upon their lips; his name is in their hearts; and he is the choice, not only of that band of young men, but he is the choice of all those who desire for the first time as young men to cast their votes in November for the candidate nominated by this Convention. They love him, gentlemen, and they respect him, not only for himself, for his character, for his integrity and judgment and iron will, but they love him most for the enemies that he has made. . . . I do not assume here to speak for labor. The child of a man who always earned his daily bread by his daily labor; brought up for more than a quarter of a century, from boyhood to manhood, among the laborers that have made the great Northwest what it is; I do not assume to speak for labor. Labor is not represented in political conventions by the soft hand of the political trickster, no matter who. The men who follow conventions and talk about the rights of labor are the Swiss contingent who place their camps wherever the pros-

1 Proceedings, pp. 122, I42, I60, 173, 179, 182, 183. 
pect of profit is greatest, while honest, intelligent, horny-handed labor will be found following the old Democratic flag, thanking God that its self-styled leaders have gone where they belonged. Men come here to talk of labor. Yes; their labor has been upon the crank of the machine; their study has been political chicane in the midnight conclave. (A voice; Give them a little more grape, Captain Bragg.) . . . .

Let our old war-horses be retired with honor. Let the record of their achievements be recorded and pointed at with pride and pleasure; but our people say give us new life, give us new blood, give us something that has come to manhood and position since the war, that we may hear no more about what took place before and during the war. ${ }^{1}$

Immediately after the nominating speeches a ballot was taken. Cleveland received votes from all but seven states, and the total vote of eight states. North Carolina and Delaware cast their total votes for Bayard, Indiana for McDonald, California for Thurman, and Kentucky for Carlisle. The vote of the other states was split, several voting for four different candidates, Missouri for five and Illinois, Tennessee and Wisconsin for six. When the vote of Illinois was announced, including one for Hendricks, Hendricks rose and said: "May I ask the gentleman that cast a vote for me from the state of Illinois to withdraw that vote? It places me wrongly before the convention." After the first ballot an adjournment was forced in spite of the efforts of some of the Cleveland men. ${ }^{2}$

During the night a plan was evidently made among the anti-Cleveland men to stampede the convention to Hendricks. The next morning during the roll call on the second ballot Illinois again announced one vote for Hendricks. At just that moment Hendricks entered the hall by a door

1 Proceedings, p. I76.

${ }^{2}$ Ibid., pp. 225, 230. 
directly facing the delegates. ${ }^{1}$ Immediately pandemonium broke loose in the galleries. The chairman, after vainly trying to get order, finally allowed the crowd to yell itself out, which it did in about half an hour. The noise was confined almost entirely to the galleries, ${ }^{2}$ the Tammany men being almost alone in their efforts to rouse enthusiasm on the floor. ${ }^{3}$ When order was restored Voorhees of Indiana took the platform and said:

I understand there is a call of the roll of the states in progress at this time. I am reminded by the Chairman that nominations are not now in order. I stand before you, however, at the unanimous request of the Delegation of which I am a member, to withdraw the name of Joseph $\mathrm{E}$. McDonald for the purpose at the proper time, of casting the vote of Indiana for Thomas A. Hendricks. ${ }^{4}$

The "stampede" did not materialize. After Voorhees' speech, the chairman of the Illinois delegation finished announcing the vote, which showed a gain of ten for Cleveland. Hendricks received a total of but $123 / 2$ votes. When the vote was announced Cleveland was still seventy-two short of the necessary two-thirds. He had gained eightythree votes, however, thirty-seven of them from Pennsylvania, Randall having been withdrawn before the beginning of the ballot. When it was seen that Cleveland had made a large gain, delegations immediately began to change their votes. North Carolina started, changing her twenty-two from Bayard to Cleveland; Virginia, Georgia, Florida, West Virginia, Texas and Missouri followed. Then Indiana, announcing that her thirty votes had been given to

${ }^{1}$ Hudson, op. cit., p. I68.

2 Proceedings, p. 237.

${ }^{3}$ N. Y. Times, World, Tribune, July 12.

"Proceedings, p. 238. 
Cleveland " on behalf of and at the request of Governor Hendricks," moved that the nomination be made unanimous. ${ }^{1}$

Cleveland's nomination was undoubtedly the strongest that the Democrats could have made under the circumstances. He had the support of the forward-looking elements of the party and was stronger with the Independents than any other candidate would have been. He was, as General Bragg had said, the candidate of the young men. The charges brought by the Republicans that he was a "political mushroom," that his views on most national questions were unknown, and that his nomination was an attempt on the part of the Democrats to avoid the old issues, were true. $^{2}$ His nomination showed a desire, on the part of a controlling element of the party at least, to break with the past and to make the question of administrative reform the prominent one in the campaign.

Several names were offered to the convention as candidates for Vice-President. The list included General Rosecrans of California, McDonald of Indiana, John C. Black of Illinois, and Gov. Glick of Kansas. Then Wallace of Pennsylvania nominated Hendricks, the " representative of the grossest wrong that was ever perpetrated upon the American people." Menzies of Indiana declared that Hendricks would not be a candidate. Waller of Connecticut, however, seconded Hendricks' nomination, asserting that Hendricks was too patriotic to refuse to serve if his party demanded it. Immediately all the other candidates were withdrawn and on the roll call Hendricks received every vote. $^{3}$

According to political wiseacres the chief function of the

1 Proceedings, p. 244.

'N. Y. Tribune, July I2, I3, I7.

3 Proceedings, pp. 254-266. 
candidate for the Vice-Presidency is to round out the ticket, attracting elements and sections to whom the Presidential candidate does not appeal. From this point of view Hendricks' nomination had certain elements of strength. $\mathrm{He}$ secured to the ticket whatever value there was in the old fraud issue. He helped to reconcile the West to an eastern candidate, the old-timers to a novice in national affairs, the soft-money men to a champion of hard money, and the machine faction to a reformer. His strength in Indiana probably carried the state for the Democrats. He did not strengthen the ticket, however, in the eyes of the groups both within and without the party who wanted Cleveland. 


\section{CHAPTER X}

The Campaign and the Election of i 884

The campaign officially opened with the customary notification of the candidates and the publication of their letters of acceptance. Neither of the letters was a document of great importance. More than half of Blaine's was devoted to the tariff and the remainder was taken up with reassertions of the vague statements of the Republican platform and attacks on the policy of the Democrats. He asserted that the civil service had been good in all Republican administrations, but that it might be improved by taking away all control over appointments from the legislature, by subjecting the executive to fixed rules, and by extending the rules to the consular service and to minor positions in the diplomatic service. " The New York Tribune declared that the letter marked Blaine as " the foremost man of his time," that it "would have done honor to any man in our history," and that "it has elevated the standard of public discussion for coming generations and raised the nation in the estimation of the wisest and best men of other lands." ${ }_{2}$ The Nation characterized it as "a collection of platitudes drawn out to the utmost limits of verbosity." 3

Cleveland, in his letter of acceptance, announced his entire approval of the Democratic platform and said that it needed no supplement or explanation. He devoted considerable attention to the necessity for civil service reform and

${ }^{1} N$. Y. papers, July 7, I884.

${ }^{2}$ July 7 .

${ }^{3}$ July 24.

375] 
for laws for the general betterment of the condition of the laboring classes. He announced himself in favor of a constitutional amendment that would limit the President to one term. He rather mildly stated his opposition to prohibition. ${ }^{1}$ As a whole his letter lacked the definiteness that characterized most of his public papers.

(The campaigns of both candidates were under the general management of their respective national committees with headquarters in New York. B. F. Jones of Pittsburg. whose main qualification seemed to be his wealth, was chosen chairman of the Republican committee. Stephen Elkins of New Mexico and New York was active in the campaign, being one of Blaine's chief advisers. ${ }^{2}$ The chairman of the Democratic committee was ex-Senator Barnum of Connecticut, a politician of the old school whose name had been connected with various scandals in former campaigns. The choice of Barnum was not satisfactory to the Independents and gave force to the Republican contention that the Democratic party was really under the control of unregenerate spoilsmen. ${ }^{3}$ Manning, chairman of the New York state committee, and Senator Gorman of Maryland took a prominent part in the management of Cleveland's campaign. The campaign set a precedent in the large number of campaign clubs of business men, bankers, lawyers, etc., formed in the interests of each candidate, and the many parades and mass meetings, characterized as crowded and wild with enthusiasm or poorly attended and unenthusiastic, according to the paper that reported them.

Contrary to custom, Blaine went on the stump himself. He started on a speech-making tour in September, speaking

${ }^{1}$ N. Y. Times, July 20.

${ }^{2}$ N'ation, June 12, August 2I ; Stanwood, Blaine, p. 269 et passim.

${ }^{3}$ Report of Nat. Ex. Com. of Reps. and Indeps. for Pres. Campaign of I884, p. $17 ; N$. Y. Time; July 25 . 
briefly en route in New York state, spending two weeks in Ohio and a short time in West Virginia, Indiana and Illinois. Returning to Maine on the eve of the election he addressed several meetings in New York city and in New England 1

Cleveland remained in Albany during most of the campaign attending to his duties as governor. He spoke at several county fairs but avoided all political questions. In the latter part of October he addressed political meetings at Newark, New Jersey, and Bridgeport, Connecticut, at both of which he emphasized the need for civil service reform and reduction of taxation and dwelt upon his friendliness toward labor. ${ }^{2}$ )

The most important event of the early days of the campaign and the one that makes the whole campaign one of unusual interest was the revolt of the Independents against Blaine's nomination. The term "Mugwumps" which was commonly applied to the Independents is of uncertain origin. It was first used in connection with the Independents by the Indianapolis Sentinel in 1872, and the New York Sun started its use in the campaign of 1884 in March of that year. ${ }^{3}$

(Although there had been several independent movements in various states, especially in New York, there had been no permanent organization on anything approaching national lines since the disintegration of the Liberal movement of 1872 . The meeting of the Independents which was held in Chicago in $1880^{4}$ had voted to maintain a permanent organization under the presidency of Wayne McVeagh, but with McVeagh's appointment to the cabinet the project had

${ }^{1} N$. Y. Tribune, Times, Oct. 1884; Stanwood, Blaine, p. 287.

${ }^{2}$ N. Y. Times, Tribune, Oct. 28, Nov. I; Parker, Cleveland, p. 70.

${ }^{3}$ Peck, Twenty Years, p. 32.

- Vide supra, p. 50. 
died. The Independent idea had been kept alive, however, in various local clubs such as the Massachusetts Reform Club and the Brooklyn Young Republican Club. ${ }^{1}$ The activities of the Independents in the campaigns for the nominations have already been described. ${ }^{2}$

In response to a call of Independent Republican committees of New York, Boston, New Haven and Buffalo an organization meeting was held in New York, July 22, attended by more than 500 accredited delegates from sixteen different states. The meeting, which was presided over by George William Curtis, after rejecting a motion to form a third party and nominate the same electors as the Democrats, appointed an executive committee to conduct the campaign and issued an address to the independent voters of the country. The address summarized the reasons for the existence of the Independents, declaring that the paramount issue of the campaign was moral rather than political, that the platforms of the two parties were not different on any great issue and that civil service reform was the most serious problem of the day. It stigmatized Blaine as

a candidate who is an unfit leader, shown by his own words and his acknowledged acts, which are of official record, to be unworthy of respect and confidence; who has traded upon his official trust for his pecuniary gain; a representative of men, methods, and conduct which the public conscience condemns and which illustrate the very evils which honest men would reform.)

Cleveland was characterized as a candidate

whose name is the synonym of political courage and honesty and of administrative reform. He has discharged every official

${ }^{1}$ Report of Indep. Ex. Com., pp. I, 2.

${ }^{2}$ Vide supra, pp. 157, 181. 
trust with sole regard to the public welfare and with just disregard of mere partisan and personal advantage, which, with the applause and confidence of both parties has raised him from the chief executive administrator of a great city to that of a great state. His unreserved, intelligent and sincere support of reform in the civil service has firmly established that reform in the State and the cities of New York, and his personal convictions, proved by his official acts, more decisive than any possible platform declarations, are the guarantee that in its spirit and in its letter the reform would be enforced in the National Administration. His high sense of public duty, his absolute and unchallenged official integrity, his inflexible courage in resisting party pressure and public outcry . . . are precisely the qualities which the political situation demands. . . . to resist corporate monopoly on the one hand and demagogic Communism on the other.... He is a Democrat who is happily free from all associations with the fierce party differences of the slavery contest and whose financial views are in harmony with those of the best men of both parties. ${ }^{1}$

The Independent national committee opened an office in New York from which literature was distributed and speakers sent out. It published during the campaign fourteen pamphlets and a large number of smaller circulars which were distributed throughout the country. The committee raised and expended more than $\$ 23,000$ and it was estimated that the amounts raised by the various state organizations would bring the total to $\$ 50,000$. Besides the national committee, local organizations were formed in Brooklyn, Buffalo, Rochester and many smaller cities in New York. In the smaller places the local clubs usually united with the Democratic Cleveland and Hendricks clubs. A headquarters was opened in Boston and local organiza-

${ }^{1} \mathrm{~N}$. Y. papers, July 23; Nation, July 24; Independent, July $3 \mathrm{I}$; Address of Nat. Com. of Reps. and Indeps. (pamphlet pub. by the com.); Report of Indep. Ex. Com., p. 4. 
tions formed at various places in Massachusetts. Local organizations were formed and a canvass independent of that of the Democrats carried on in Rhode Island, Connecticut, New Jersey, Pennsylvania, Ohio, Indiana, Illinois, Wisconsin and Iowa. ${ }^{1}$ The national organization was kept distinct from that of the Democrats although frequent consultations with them were held. The Democrats made a great deal of the movement, quoting widely from speeches of the Independents in their meetings and in their literature. ${ }^{2}$

Among the more prominent speakers for the Independents were Schurz, Curtis and Henry Ward Beecher, of New York, and Thomas W. Higginson and Josiah Quincy of Boston. Schurz especially did valiant work. His speech at the Brooklyn meeting of August 3, in which he thoroughly analyzed Blaine's record and summed up the position of the Independents, was one of the principal documents of the campaign, being widely circulated and quoted. ${ }^{3}$ He made a western trip in September, speaking in Illinois, Indiana and Ohio. Other prominent men identified with the movement were Benjamin H. Bristow, Francis A. Walker, President Seelye of Amherst, Samuel Bowles, Rev. James Freeman Clark and Charles R. Codman.

Among the Republican and independent newspapers and periodicals that refused to support Blaine were the Nation and Harper's Weekly, the Herald, Times, Evening Post and Evening Telegram, of New York, the Brooklyn Union, the Post-Express and the Herald of Rochester, the Syracuse Herald, the Advertiser, Transcript and Herold of Boston, the Times and the Record of Philadelphia, the

${ }^{1}$ Report of Indep. Ex. Com., passim.

${ }^{2}$ Vide Dem. Camp. Textbook, pp. 280-297.

${ }^{3}$ Schurz's speech was published as a pamphlet both in English and in German by the Independents. 
Times and the News of Chicago, the New Haven Neres and the Springfield Republican. The St. Louis Globe Democrat, the Buffalo Commercial Advertiser, the Albany Express, the Troy Times and the Philadelphia Evening Telegram, which had opposed Blaine before his nomination, supported him in the campaign. ${ }^{1}$

There were several men who had been prominent in the movement for reform, some of whom had bitterly opposed Blaine's nomination, who refused to bolt the ticket. Among them were Andrew D. White, Theodore Roosevelt and Hamilton Fish of New York, Henry Cabot Lodge and Governor Robinson of Massachusetts and Senator Edmunds of Vermont. Some of these admitted that they had the highest respect for Cleveland and would prefer him to Blaine, but they distrusted the Democratic party, feeling that there was no hope of reform with it in power. ${ }^{2}$ To others party loyalty was decisive. They felt bound to support any nominee of the party and emphasized the fact that Blaine's nomination had been fairly made and that there had been no protest against it on the floor of the convention. $^{3}$ This argument naturally appealed strongly to those who held office as Republicans or were candidates on the Republican ticket. There was but little attempt from any of this group to defend Blaine. Senator Edmunds, after having refused to speak in the campaign, finally made a speech in which he praised the Republican party, although expressing some sympathy for the "kickers," but had not a word to say about Blaine." The Republicans laid the

1 Nation, July I2.

2 White, Autobiog., p. 208; Independent, July I7; Harper's Weekly, Aug. 2; N. Y. Evening Post, Oct. 21 ; Nation, Sept. 18.

${ }^{3}$ Schurz, Works, vol. iv, p. 218, letter of Lodge to Schurz; N. Y. Times, July 21, Oct. 19, interview and speech of Roosevelt.

'Nation, Sept. 4. 
blame for the falling off of their vote in the Vermont election which was held in September to Edmunds' lukewarmness. ${ }^{1}$ The leaders of the movement against the Cameron machine in Pennsylvania in I882 issued an address as Independents, which was made much of by the Republican papers, urging all Independents to vote for Blaine. This group had always been, however, an anti-Stalwart rather than an Independent one and many of them had been enthusiastic workers for Blaine's nomination. ${ }^{2}$

The Stalwarts in general supported the ticket; at least, few of them aligned themselves with the Independents. To bolt openly a regular nomination was contrary to their whole conception of politics. Although it was reported that the Blaine leaders and Blaine himself were anxious to have Conkling's support or his endorsement at least, Conkling refused to have anything to do with the campaign and was commonly supposed to be secretly supporting Cleveland. ${ }^{3}$ After the election Conkling worked with a committee of Independent and Democratic lawyers to ensure a fair count for Cleveland. ${ }^{4}$ A group of Stalwarts from Conkling's home county, Oneida, issued a statement condemning Blaine and announcing their intention to support Cleveland. ${ }^{5}$ Several who ought to be able to speak with authority have assigned the Stalwart defection, due to the old feud between Blaine and Conkling, as the primary cause of Blaine's defeat. ${ }^{6} \quad$ There seems to be little evidence, however, to sup-

1 Nation, Sept. II.

${ }^{2}$ N. Y. Times, July I4; Nation, July I7; also vide supra, p. 69.

${ }^{3}$ Vide letter from Blaine to Elkins, Stanwood, Blaine, p. 285; Hudson, Recollections, p. I99; N. Y. Times, Aug. 17, Nov. 2.

${ }^{4}$ Stetson and Rice, article in North American Review, Jan. I9I4.

${ }^{5}$ N. Y. Times, Oct. 24.

6 Platt, Autobiog., p. I86; McCall, Life of Thomas B. Reed, p. I29; McClure, Recollections, p. I22; N. Y. Sun, Nov. 8, 1884 . 
port this view. Such opposition as there was to Blaine among the Stalwarts came mainly from Conkling's personal following and Conkling was not the type of leader to be able to hold any great number once his control of the patronage was lost.

The Republican newspapers and orators devoted a large part of their attention, especially in the earlier part of the campaign, to the Mugwumps. "Ishmaelites," "Dependents," “ "Soreheads," “Pharisees," “ Political Hermaphrodites," "Goody-goodies," " Assistant Democrats" were among the terms used to describe them. At first the Republicans attempted to ridicule the movement and to minimize its importance. Senator Hoar, who had so often eloquently championed reform, spoke of the Independents as follows :

President Eliot expresses the sentiment of a little body of men about Cambridge,-I am happy to believe that he does not represent the college,-whose influence, in my judgment, has tended infinitely to degrade the public life of the Commonwealth. These men have taught our educated youth to be ashamed of their own history. They have told them that " since the close of the war there has been no time when a young man knew how he could honorably serve his country." They were preaching in the same strain during the war and before the war. . . . There is hardly a man who has taken any of the responsibilities of public life who has not been compelled to undergo the contemptuous criticism of these gentle hermits of Cambridge. ${ }^{1}$

(Later the Republicans began to speak of the wickedness of not supporting a ticket which had been nominated fairly and to point out the natural depravity of the Democrats and the hopelessness of the reformers' attempt to accom- 
plish anything through them. Old attacks on Democrats, especially on Hendricks, were brought up against Curtis and other reformers. ${ }^{1}$ )

The favorite way, however, of disposing of the Independents was to declare that they were all free-traders who, having failed to get a free-trade candidate, were bent on destroying the Republican party. Much was made of a letter written by Curtis to an Independent in Pennsylvania before the Republican convention, in which he said that the Independents of New York were anti-protectionist and that a candidate to get their support must favor revenue reform. " The old stories of "British gold" were revived and the Independents were characterized as the "British party" and the "New York Cobden Club." 3 This argument had the double advantage of demolishing the Mugwumps and at the same time lending color to the Republican contention that the tariff was the main issue.

It is indisputable that a great majority of those who joined the Independent movement were in favor of revenue reform and that the Democratic party with Cleveland offered more promise of such reform than did the Republican with Blaine. There were, however, many ardent protectionists in the movement and the Independents as a whole had shown their willingness to support Edmunds whose attitude was distinctly favorable to protection. ${ }^{4}$ The Independents announced in their address to the voters that there was a difference of opinion on various matters among those who had joined the movement and advised the voters

1 The N.Y. Tribune made good use of Curtis' speech in the Republican convention, castigating the Democrats, vide $N$. Y. Tribune, JulyOct., especially July 8, Nov. I; Curtis, Republican Party, vol. ii, p. 156.

${ }^{2}$ N. Y. Tribune, Oct. 24.

${ }^{3}$ Ibid., Oct. I.

${ }^{4}$ N. Y. Times, Oct. 9; Harper's Weekly, Sept. Is. 
to use their own discretion in voting for members of Congress. The Independent committee issued a special pamphlet on the tariff in which they asserted that all the talk about the tariff was simply an attempt to divert attention from Blaine's record. They pointed out the similarity of the two platforms on the question, the fact that a large element in the Democratic party, as shown by its votes in Congress and its state platforms, favored protection, and finally that the President by himself had but little power over the tariff. ${ }^{1}$

There seems to be no reason to believe that the Independent movement was to any great extent a free-trade movement or that it was anything else than what it professed to be, an organization of men who felt that with no great issues between the parties the main question was one of administrative reform, that, whatever the record or personnel of the parties, Cleveland offered more promise of reform than did Blaine, that Blaine's record showed him to be a man to whom it would be unsafe to trust the Presidency, and that the first duty of every voter was to put the common good above the good of his party.

It was inevitable that Blaine's railroad dealings should play a prominent part in the campaign. The Independent papers had published all the details in their attempt to defeat his nomination. ${ }^{2}$ The Democratic papers before his nomination generally assumed the attitude that the Independents were over-particular in opposing him, but as soon as he was nominated they joined in a grand chorus of condemnation. ${ }^{3}$ Blaine's record was introduced at practically every Democratic or Independent meeting, and in many it was the only subject of discussion. Each day during the

${ }^{1}$ Pamphlet issued Oct. I6.

${ }^{2}$ Vide supra, p. 157.

${ }^{3}$ N. Y. World, N. Y. Sun, June 9-15. 
later weeks of the campaign the Evening Post published in parallel columns, under the title "The Blaine Falsehoods Tabulated," Blaine's various statements and extracts from the Mulligan letters contradicting them. Nast's cartoons in Harper's Weekly ridiculed the idea that Blaine was either statesmanlike or honest. The tactics of the Republicans were either to ignore the subject altogether, to assert that the charges were groundless lies similar to the attacks that had been made on all great leaders from Washington's time on, or to take one small point and, having refuted that, to assume that the whole question had been settled. ${ }^{1}$ The Independents complained that the Republican papers never published either the charges or the vindications in full but merely said that this man or that had answered all charges. ${ }^{2}$ Of all the attempts to defend Blaine, that of Senator Hoar was the strongest, ${ }^{3}$ but it was far short of being a complete answer to the charges, as Schurz showed in his answer. ${ }^{4}$

On September I 5 a new lot of Mulligan letters was published. These letters, which had been in the possession of Mulligan and Fisher and were now published through action of the Independent committee, ${ }^{5}$ contained nothing of importance that was new but did make Blaine's guilt seem more probable. The genuineness of the letters was admitted, Blaine declaring that his only desire was that every voter in the United States might read them in full. ${ }^{8}$ The

${ }^{1} N$. Y. Tribune, July 16 , speeches of Hawley, Smith and Evarts at ratification meeting in N. Y., and of Hoar, Lodge and Dawes at ratification meeting in Boston; also Tribune, Aug. 4, I9, Sept. I7, I8, Oct. I, No. $2,7$.

${ }^{2}$ Nation, Sept. II, I8, 25.

${ }^{3}$ N. Y. Tribune, Aug. 26.

$N$. Y. Evening Post, Sept. I ; also published as pamphlet by Indep. Ex. Com.

${ }^{5}$ Report, p. 16.

- V. Y. Times, Sept. I6. 
Tribune claimed that they were really of great help to Blaine, as some of them showed how anxious he was that none of his friends should lose by transactions in which he had interested them. ${ }^{1}$ Fisher later made the assertion that Blaine had offered him \$10,000 for the letters and had also offered to pay the expense of a trip to Europe for Fisher and Mulligan which should last till after election. This was denied by Blaine but was reiterated by Fisher. ${ }^{2}$

In addition to the Little Rock affair there were other instances of Blaine's alleged friendliness to privilege-seeking corporations. During Blaine's term in the Senate Thurman introduced a bill which would compel the Union Pacific Railroad to establish a sinking fund and pay into it twentyfive per cent of its yearly earnings until its indebtedness to the United States was cancelled. Blaine proposed an amendment to the bill the effect of which would have been to prevent Congress passing any further laws for the regulation of the Union Pacific for a period of twenty years. ${ }^{3}$ The amendment was defeated and Blaine voted against the bill on its final passage. ${ }^{4}$ This was brought up against him in the campaign, it being claimed that he would not enforce the law or that he might appoint judges to the Supreme Court who would overthrow it. ${ }^{5}$ The charge was also made that Blaine held stock in the Hocking Valley Mine of Ohio where a dispute about wages had led to a strike. Strike-breakers had been imported and violence resulted, which continued throughout the summer and attracted a great deal of attention. ${ }^{6}$ Blaine denied that he owned or

${ }^{1}$ Sept. 16.

${ }^{2}$ N. Y. Times, Oct. 6, Io, II ; Nation, Oct. 9.

${ }^{3}$ Cong. Rec., 45 C., 2 S., p. 233 I.

${ }^{4}$ Ibid., p. 2384.

${ }^{5}$ N. Y. Times, Aug. 8, Oct. 29, 31 .

- Ann. Cyc., 1884, p. 631. 
ever had owned any stock in the company, and it later developed that his interest had been an option on stock. ${ }^{1}$

Various other rumors of Blaine's financial dealings and his willingness to use his official position to advance his own interests arose during the campaign. ${ }^{2}$ Most of these were unsubstantiated but they helped lend color to the charge made against Blaine by his opponents that he was the friend of all that element in financial circles which was trying to get rich through stock manipulation and was seeking favors from the Government to promote the enterprise. The conspicuous examples of this group in the public mind were Cyrus W. Field, Russell Sage and Jay Gould, all of whom supported Blaine. ${ }^{3}$

The charge that Blaine was the candidate of the predatory and unscrupulous financial interests was urged most vigorously in the closing days of the campaign. According to one authority who is most sympathetic toward Blaine, Blaine's trip to New York in the latter part of October was taken against his own better judgment and at the insistence of Jones, the chairman of the national Republican committee, for the purpose of inducing certain financiers to contribute to the campaign fund . A dinner was given for him at Delmonico's which was attended by many of the notoriously wealthy men of New York. Reporters were excluded, only Associated Press men being allowed to be present for a part of the time. ${ }^{5}$ The next day and for days afterward the Democratic and Independent press was filled with stories of this "millionaire dinner," with rumors of what had taken place and what fabulous sums had been contributed to the campaign fund.

${ }^{1}$ Nation, Oct. 9.

${ }^{2}$ Vide statement of H. W. Beecher in Nation, Oct. 9.

3. Vation, July 17.

${ }^{4}$ Rogers, Development of the North, p. 148 .

${ }^{5}$ Nation, Nov. 6. 
The characterization of Blaine as the candidate of the capitalists was in part an attempt to answer the charge that Cleveland was the enemy of labor. Cleveland's record on labor questions had caused some dissatisfaction which was carefully nursed by his opponents. The attention given to labor in Cleveland's letter of acceptance and ir his two speeches of the campaign, as well as the amount of space devoted to the record of Cleveland and of the party on labor question in the Democratic Campaign Textbook ${ }^{1}$ is evidence that the Democrats realized the importance of the issue.

The attack on Cleveland as the enemy of labor was led by Benjamin Butler. Although the Greenback party had been in the past largely a farmers' party, ${ }^{2}$ Butler devoted most of his attention to the labor vote. Butler waited until August before announcing that he would stand as the candidate of the Greenback and Anti-Monopoly parties. ${ }^{3}$ Later, in a long, rambling and disconnected letter to his "constituents" he gave his views on the issues of the campaign. He declared that his main political interests were hostility to all monopolies, preservation of the legal tender notes, protection of the workers against capital and reform in administration. He told his version of the Democratic convention, denouncing the Democratic platform as a mere vote-catcher and the Republican party as the party of privilege and monopoly. He warned the workers that "those who ape the British aristocracy" were trying to get control of the government, and that workingmen could hope for nothing from either of the old parties. He urged that his followers in each state unite with the minority, nominating the same electoral ticket, with the agreement that

${ }^{1}$ Pp. 179-245.

${ }^{2}$ Commons, op. cit., p. 440.

${ }^{3}$ N. Y. Sun, Aug. 7. 
the electoral vote of the state be divided according to the number of votes cast by each party. ${ }^{1}$ This plan of fusion was adopted in some cases, the Greenbackers fusing with the Republicans in West Virginia and Missouri and with the Democrats in Michigan and Iowa. ${ }^{2}$ Butler carried on an active campaign, addressing meetings of workingmen and farmers in New England, New York and Pennsylvania." In his speeches, when dealing with the conditions of labor, he often urged measures for improvement that have since come to be looked upon as sound and necessary, but they were so intermingled with cant and appeals to ignorance that many of the more intelligent of the labor reformers distrusted him. ${ }^{4}$

The charge was made and quite generally accepted, except by Blaine partisans, that Butler was merely a stalking horse for Blaine in the campaign. The story went that Butler met Chandler, the Secretary of the Navy, in Portsmouth, New Hampshire, on July 26, that Chandler then went to Bar Harbor where he held a conference with Blaine and some of the Republican leaders and then had another conference with Butler at Portsmouth on August 4. Following this last conference Butler announced that he would make the canvass as the candidate of the Greenback and Anti-Monopoly parties. ${ }^{5}$ This story fits in well with Butler's action in delaying so long before accepting the nominations and was never formally denied by Butler. Later in the campaign General W. H. Parsons, chairman of the Greenback-Labor Committee of Maryland, made the state-

${ }^{1}$ N. Y. Times, Aug. I9.

${ }^{2}$ Ibid., Aug. I6, 21, Sept. 4, II ; Ann. Cyc., 1884, p. 775.

'N. Y. Times, Aug. 20, 30, 31, Sept. 19.

"George, Life of Henry George, pp. 449, 506; Hillquit, History of Socialism, p. 270.

${ }^{5}$ N. Y. Times, Aug. I7; Nation, Aug. 21; Harper's Weekly, Aug. 30. 
ment that Butler's campaign was being financed by the Republicans. He declared that he had gone to New York to get Butler to come to Maryland to speak and had been referred by Butler's manager to the Republican national committee, which, the manager said, was directing Butler's campaign. ${ }^{1}$ Parsons further declared that the books of the First National Bank of New York would show that a check for $\$ 5,000$ had been drawn by Jones, the Republican chairman, to Butler's manager each week of the campaign. ${ }^{2}$ This whole story was vehemently denied by Butler. ${ }^{3}$

(The attitude taken by the New York Tribune and the New York Sun, the leading organs of Blaine and Butler respectively, strengthen the suspicion that Blaine and Butler. were working in harmony.) (The Tribune was throughout the campaign rather favorable to Butler) The general tone of its editorials was that Butler was pretty bad, but not any worse and probably a great deal better than the average Democrat, that although he was a demagogue he was one. with some honesty, while Cleveland and his supporters were demagogues and hypocrites as well. ${ }^{4}$ The Sun attacked: Blaine at the beginning of the campaign and, although it had opposed Cleveland's nomination and had been most unenthusiastic about him, it did not come out openly against him until after Butler had accepted the Greenback nomination. The attack on Cleveland's moral character gave it the opportunity to throw him over completely. Throughout the last two months of the campaign its editorials showed that it was more anxious to defeat Cleveland than anything else. While singing Butler's praises it lost no opportunity to say that as between Blaine and Cleveland, Blaine was much to

${ }^{1}$ N. Y. Times, Oct. 19, 20.

${ }^{2}$ Ibid., Nov. 2.

${ }^{3}$ Ibid., Oct. 20; N. Y. Tribune, Oct. 21 ; Ann. Cyc., I884, p. 774.

${ }^{4} N$. Y. Tribune, Aug. 19, 20, 25, 31. 
be preferred. (The last month before election it printed each day a front-page article on Cleveland's enmity to labor. These articles, under such headings as "The Workingman's Enemy" or "The Foe to Honest Labor," consisted mainly of interviews with individual workingmen who were opposed to Cleveland and who usually "knew of at least twenty others in this vicinity "who were of like opinion.)

While definite proof is lacking and would be very hard to get, the probabilities are that Butler had an understanding at least with the Republicans. In the account of the campaign given in his " book" Butler mentions no other reason for running than his desire to defeat Cleveland, giving as the reason for his opposition to Cleveland the fact that he considered 'Cleveland's nomination to be a free-trade victory and was fearful of grave dangers to the country in case of his election. ${ }^{1}$

An unusual and a disgraceful feature of the campaign was the attack made on the private life and moral character of both candidates, particularly on that of Cleveland. The Buffalo Evening Telegraph of July 2 I published a story charging Cleveland with being a libertine and a drunkard and giving details of his illicit relations with a woman of Buffalo. This story, which was vouched for by two Buffalo ministers, created a great sensation and caused even staunch supporters of Cleveland to waver. ${ }^{2}$ Demands were made that Cleveland withdraw from the canvass. The Independent, which had supported Cleveland, came out against him. ${ }^{3}$ Investigations were made by a committee of Independents of Buffalo, by the Rev. Kinsley Twining of the Independent and by the Buffalo association of minis-

${ }^{1}$ Butler's Book, pp. 982,983 .

${ }^{2}$ Schurz, Works, vol. iv, p. 222, letter of H. W. Beecher.

${ }^{3}$ Independent, Aug. 2r, Sept. Ir. 
ters. The Buffalo ministers divided, some of them declaring that enough had been proven to show that Cleveland was an unfit man to be President, and others that the facts did not warrant any such conclusion. The Independent committee and Mr. Twining reported that Cleveland had had, some eight years previously, a liaison with a Buffalo woman, but that there was no evidence of seduction or breach of promise and that Cleveland had accepted his responsibilities and made ample amends. Cleveland frankly admitted this part of the scandal. The general charges of intemperance and unchastity, the committee declared, were entirely unfounded. The newspaper in which the charges appeared had no standing in the community and the editor refused to furnish proofs of the statements made. The charges were mainly vague and general and therefore difficut to answer but every specific charge was traced to its source and found groundless. ${ }^{1}$

The scandal died down for a time but with the publication of the new Mulligan letters in September it was revived. Stories of Cleveland's general immorality and drunkenness were printed and sent broadcast over the country, especially to women and ministers. ${ }^{2}$ Republican speakers, while not usually making open accusations, kept the charges alive by underhand innuendo. ${ }^{3}$ The charge has been made that Blaine himself first sent the story to the Republican National Committee. ${ }^{4}$ At least he made no effort to stop its use in the campaign.

${ }^{1}$ Report of Com. of Indep. Reps. of Buffalo (pamphlet pub. by Indep. Ex. Com.) ; Independent, Aug. I4; N. Y. Times, Aug. I2; Peck, Twenty Years, p. 34; Harper's Weekly, Nov. I ; N. Y. Sun, Aug. 7, 9, Oct. 15, 16; N. Y. Eve'g. Post, Aug. 5, 6, Oct. 14, 15.

${ }^{2}$ Nation, Oct. 23.

'Vide especially speech of Edwards Pierpont at N. Y. Academy of Music in N.Y. Times, Nov. 2.

'Peck, Twenty Years, p. 34; McClure, Our Presidents. จ. 312. 
An attempt at an answer in kind was made by the publication in the Indianapolis Sentinel of August 8 of what purported to be an account of Blaine's early family history. Blaine immediately began a suit for libel against the Sentinel and published a letter explaining the situation which satisfactorily quieted the scandalmongers. ${ }^{1}$ It is claimed by Cleveland's friends that he ordered that the Democratic managers pay no attention to the charges against Blaine and that he destroyed documents sent to him which were supposed to support the charges. ${ }^{2}$

So much attention was devoted to the Mugwumps, to Blaine's record and to Cleveland's moral character in the campaign that there was little time left to discuss differences in party policy, had there been any to discuss. The Southern question received comparatively little attention. Some orators touched on it, in referring to the menace of the solid South, or in such general terms as that "the party which attempted to destroy the Union should never be permitted to govern it." " The Republican Campaign Textbook described the "recent outrages" in Copiah and Danville as steps in the Democratic plot to seize the government." In his speech of acceptance Blaine said: "Can anyone doubt that between the sections confidence and esteem are to-day more marked than at any period in the sixty years preceding the election of President Lincoln?" His esteem for the South, however, did not prevent him from pointing out, in his speeches in Indiana, the danger of returning the Democrats to power, three-fourths of whose strength was in the South, "the old South with its bitterness, its un-

${ }^{1}$ N. Y. Sun, Aug. $15 ;$ N. Y. Times, Sept. 20.

${ }^{2}$ Feck, Twenty Years, p. 37 ; Hudson, Random Recoll., p. 184. Report of Indep. Ex. Com., p. I5.

${ }^{3}$ N. Y. Times, Oct. 24.

4. 152. 
reconciled temper, its narrowness of vision, its hostility to all Northern interests, its constant longing to revive an impossible past." 1

"The Democrats had shown by their record, their platform and their candidate that they wished to keep the tariff question in the background. Their newspapers and their speakers strenuously insisted that it was not an issue. ${ }^{2}$ Cleveland made no mention of the tariff in his letter of acceptance and throughout the campaign gave no hint of the strong stand he was to take later on the question. His only public utterance on the question of revenue or the tariff was in his speech at Newark, where he repeated the formula of the platform that the tariff must be reduced but in such a way as not to injure labor. ${ }^{3}$ ) The Independents also insisted that the tariff was not an issue, but in spite of all that they or the Democrats could do or say the Republicans forced it to the front on every occasion. No meeting and hardly any speech was. complete without some reference to it. ${ }^{*}$ All the progress of the nation was accredited to the protective system and it was taken for granted by the Republican orators that Republican defeat meant the overthrow of that system. The Republican Campaign Textbook for I884 devoted seventy of its one hundred and seventy pages to the tariff, including elaborate tables showing differences in wages in the United States and England.

(Blaine, if not the originator of the idea of making the tariff the main issue, was at least thoroughly in accord with it.) More than half of his letter of acceptance was devoted

${ }^{1}$ N. Y. Times, Evening Post, Oct. 24; Blaine's Political Discussions, p. 454 .

${ }^{2}$ N. Y. World, June 15 , Nov. 3.

${ }^{3}$ N. Y. Times, Oct. 28.

4 ide accounts of Republican meetings in N. Y. papers of July I6, Aug. 22, Oct. 10, 24. 
to the tariff. In common with other Republican writers and speakers, he had no specific recommendations to make, but stated that the Republican party was traditionally in favor of protection and the Democratic traditionally opposed. He compared the total wealth and general business conditions of the country in I860 and I884 and, by implication at least, gave to the protective tariff the credit for the development. "Even the opponents of the present revenue system," he said, " do not pretend that in the whole history of civilization any parallel can be found to the material progress of the United States since the accession of the Republican party to power." He professed, as did other orators of both parties, to be mainly concerned with the welfare of labor, and dire consequences to the workingmen were prophesied as a result of any attack on the protective system. ${ }^{1}$ In his speeches during the campaign he kept the tariff question in the foreground, especially on his tour through Ohio, where an increase in the rates on wool was promised and where many entire speeches were taken up with the question. ${ }^{2}$ His general line of argument was to ignore the existing depression and dilate on the material progress of the country since 1860 , giving the tariff as the cause of this progress and assuming that the only way to continue protection and progress was to keep the Republicans in power. It was noticeable that in his speeches to the business men of New York city, where many Republicans were only lukewarm for protection, he had little to say about the tariff but talked more of the attack on sound money and the national banking system that was to be expected from the Democrats. ${ }^{3}$ In his speech at Augusta on the night of the Maine election he

${ }^{1} N$. Y. Times, July I9.

${ }^{2} N . Y$. Tribune, Oct. 2, Io; N. Y. Times, Oct. 6, 10, 16.

'N. Y. Times, Oct. 3I, Nov. I, 2. 
said, "our campaign has been conducted on one great issue. . . . It is the issue of protection to American labor." Later in the same speech, in explaining his attitude on the prohibition question, he said: "Judicious friends of a protective tariff, which is the practical issue of the campaign, will not divert their votes to the question of prohibition, which is not a practical issue in the national campaign." 1 In his final speech of the campaign, made in Boston the night before election, Blaine plainly stated that protection was, in his opinion, the foremost issue. In explaining why he had toured the country contrary to the usual custom, he said: "I did it, too, for the more specific reason that I believed there was a danger lest the leading question which related to the Protective System of America should be partially or perhaps wholly excluded from that consideration by the people which its merits deserved." 2

It is difficult to believe that the action of Blaine and the Republican leaders in attempting to make the tariff the main issue of the campaign was sincere. The question of the merits of protection as a policy was not involved. The Democratic party, it is true, had been traditionally opposed to protection, but the attitude of the party had changed both in theory and practice, as is shown by their action in Congress and their platform. Both parties agreed that there were inequalities in the tariff that should be removed, and both were also agreed that it should be done in a way that would leave the main idea of protection intact. To ignore the change that had taken place in the Democratic party and to assume that all Democrats were free-traders in disguise was either unintelligent or demagogical. It was certainly demagogical to claim that all the prosperity of the

${ }^{1}$ N. Y. Times, Sept. 9.

'Blaine's Political Discussions, p. 465. 
country was due to protection, "denying to nature the credit of her bounty and to labor the credit of its toil and skill," 1 ignoring the existing business depression or blaming it on the fear of Democratic tariff changes. The charge that the Republicans forced the tariff question to the front to divert attention from Elaine's record seems to be justified.

The strength of the Prohibitionists was a source of considerable worriment to the Republicans. The Tribune tried to reason with them, showing them how they were voting against their own interests and strengthening the Democrats. It declared that St. John's letter of acceptance, in which he said that both the old parties favored the continuation of the liquor traffic, was a libel on the Republican party and showed conclusively that St. John's campaign was being managed in the interest of the Democrats. ${ }^{2}$ The New York State Temperance Assembly at a meeting held in Brcoklyn, October 8, adopted resolutions, signed by Theodore Woolsey, Thomas Talbot, Noah Davis and others, asking St. John to withdraw on the ground that his candidacy was aiding the Democrats, who were unfit to govern. ${ }^{3}$ When St. John refused to withdraw, the Republican papers began a systematic attack on him which so angered St. John that he announced that he would cancel all his other engagements and come to New York to fight Blaine where he could harm him most. He made several speeches in western New York in which he particularly ridiculed the Republican claims for protection, declaring that the tariff protected monopoly more than the workers. ${ }^{4}$

${ }^{1} N . Y$. Times, Sept. 28.

${ }^{2}$ N. Y. Tribune, Aug. 23, 26, 29, Oct. 2.

3 Ibid., Oct. II ; Ann. Cyc., I884, p. 774.

${ }^{4}$ N. Y. Times, Oct. $2 \mathrm{I}, 25,28$. 
Maine voted in September on a constitutional amendment prohibiting the manufacture and sale of liquor, but Blaine carefully avoided taking a stand on the question. In a speech in Augusta on election night he said: "For myself I decided not to vote at all on the question. I took this position because I am chosen by the Republican party as the representative of national issues, and by no act of mine shall any question be obtruded into the national campaign which belongs properly to the domain of state issues." 1

The Prohibition party was recruited from the Republicans rather than the Democrats, not only because the traditional political philosophy of the Democrats was opposed to the limitation of the freedom of the individual, but also because the Republican party contained a large element which had been attracted to it by the moral issues involved in the slavery question and which had to have some moral stimulus to keep it interested in politics. The Prohibition party offered an outlet for this moral enthusiasm. It proposed to direct the power of the law against a great evil and Republicans had long been trained to believe in the power of the law. ${ }^{2}$ Circumstances favored the Prohibitionists in 1884 . There were no great issues between the parties to distract attention from their own particular one. Many voters normally Republican distrusted Blaine but could not bring themselves to vote for a Democrat or were repelled by the charges of immorality made against Cleveland. After the election St. John issued a statement in which he claimed the credit for having elected Cleveland, ${ }^{3}$ and his contention has considerable force. His vote in New York, Connecticut and New Jersey was larger than Cleve-

${ }^{1}$ N. Y. Times, Sept. I9.

${ }^{2}$ Ibid., Aug. I8, Sept. I8.

${ }^{3}$ Ibid., Nov. 12. 
land's plurality in those states. ${ }^{1}$ Of course it is not true that all of his votes would have been cast for Blaine if there had been no prohibition ticket, but his 25,016 in New York doubtless included enough that would have been cast for Blaine to change the result of the whole election.

There was a great deal of discussion as to what attitude Tammany, after its rebuff at the Democratic convention, would assume toward the ticket. The Tammany leaders appointed a committee to take up the question of endorsing Cleveland and this committee said in its report: "The candidate of the Democratic party having been nominated in the National Convention, following the uniform and unbroken record of our organization, we acquiesce in the will of the majority of the representatives of the party although we believe that will to have been unwisely expressed." The report was adopted, although Grady opposed it and announced his intention of supporting Butler. ${ }^{2}$ Grady carried out his threat and campaigned for Butler. ${ }^{3}$ John Kelly and other leaders spoke for Cleveland during the campaign, but they were not at all enthusiastic. ${ }^{4}$ On city offices Tammany made no attempt to combine with the other Democratic factions but nominated a straight ticket. The Republicans also nominated a straight ticket, while a citizens' committee nominated a third ticket, which was endorsed by the County Democracy, Irving Hall and the Anti-Monopolists. ${ }^{5}$ Just before election Tammany sent out circulars lauding its candidates and containing ballots to be cast for city officials, but nothing was said of Cleveland and there were no ballots with the names of his electors. ${ }^{6}$ In the election Grant,

${ }^{1}$ Stanwood, Presidency, p. 448.

${ }^{2}$ N. Y. Times, Tribune, Sept. 13.

${ }^{3} N$. Y. Tribune, Oct. 28.

${ }^{4} N$. Y. Times, Sept. 30.

${ }^{5}$ N. Y. papers, Sept. 30, Oct. 21, 22, 23.

- N. Y. Times, Nov. 4. 
the Tammany candidate for mayor, received 20,000 more votes than Tammany was expected to poll normally, while counting the Republican votes which Cleveland probably received, his vote was 20,000 short of what it should have been. This led to the charge that a deal had been made between Tammany and the Republicans by which Republican votes were cast for Grant in return for Tammany votes for Blaine. $^{1}$ Tammany accused Irving Hall of having sold out in return for votes for Grace, the fusion nominee. ${ }^{2}$

A great deal was heard during the campaign of the Irish vote and the German vote. The German-Americans had been largely Republicans but many of them were opposed to prohibition and were turning to the Democrats on that account. The influence which Carl Schurz had with the Germans was also a factor in attracting them to Cleveland. A large meeting of Germans was held in New York, September 29, which was enthusiastic for Cleveland. ${ }^{3}$ Blaine was thought to be particularly strong with the Irish. The reasons usually given were that he was of Irish descent and that he had been particularly active while Secretary of State in looking out for the interests of American citizens of Irish descent imprisoned in England. ${ }^{4}$ The records do not show that Blaine had been either particularly active or successful in behalf of naturalized Irishmen ${ }^{5}$ but he had shown an anti-British feeling which endeared him to all the "professional "Irishmen who hoped for a "vigorous foreign policy" against Great Britain. The Irish World, the American organ of the Irish Land League, was enthusiastic in its support of Blaine and in condemnation of Cleveland as

${ }^{1}$ N. Y. Times, Nov. 6, 8; N. Y. Er'ening Post, Nov. 14.

'N. Y. Tribune, Nov. II.

${ }^{3} N$. Y. Times, July 8 , Sept. 30.

Hamilton, Blaine, pp. 574, 584; Stanwood, Blaine, p. 286.

${ }^{5}$ Vide supra, p. 154. 
the "British" and the "Cobden Club" candidate. It appealed to all Irishmen to support Blaine, declaring that a sufficient reason for doing so was that all the great London dailies were opposed to him. ${ }^{1}$ An enthusiastic Blaine meeting was held by the Irish in New York July 28, at which a telegram from Blaine was read thanking them for their "friendly assurances." The Democrats, refusing to be outdone, held a Cleveland Irish meeting August 28. ${ }^{2}$

As a part of the Irish propaganda for Blaine an attempt was made to show that Cleveland was a "Presbyterian bigot." This charge seems to have been based on the fact that Cleveland's father had been a Presbyterian minister and that Cleveland had vetoed the Catholic Protectory bill. ${ }^{3}$ Many of the clergy of the Roman Catholic Church, including the Bishop of Albany, resented the attempt to drag the church into politics and came out with endorsements of Cleveland, as did some of the Catholic papers. ${ }^{4}$

One of the most important events in this attempt to mix politics with religion and race prejudice occurred in the closing days of the campaign. While in New York Blaine was given a reception by a delegation of local ministers. A Rev. Mr. Burchard, who was chosen spokesman for the group, in the course of his remarks characterized the Democratic party as the party of " Rum, Romanism and Rebellion." Blaine in his reply made no mention of this remark. The occurrence was immediately reported to the office of the Democratic National Committee and was seized upon as a means of undermining Blaine's Catholic support. It

${ }^{1}$ Irish World and American Industrial Liberator (New York), June 28, July 5, 12, 26, Aug. 9, 16.

${ }^{2} N$. Y. Times, July 29, Aug. 29.

3 Vide supra, p. I79; Hudson, op. cit., p. I64.

"Cary, Life of Curtis, p. 28I ; N. Y. Herald, Oct. 6; N. Y. Times, Oct. I, II ; Nation, Oct. 30. 
was telegraphed all over the country, was featured by Democratic papers and also circulated by means of handbills. ${ }^{1}$ In some cases the remark was attributed to Blaine himself. ${ }^{2}$ Blaine in an interview at New Haven, November I, denied that the remark expressed his sentiments in any way, pointing out the fact that although a Protestant himself, his mother had been a Roman Catholic. ${ }^{3}$ It was later reported that Blaine had not been paying attention to the remarks of Mr. Burchard and had not heard the phrase at all. ${ }^{4}$ This incident has attracted an unusual amount of attention and has often been cited as the deciding factor in Blaine's defeat. ${ }^{5}$ Although it probably did influence some votes, the importance of the incident can be easily overestimated because of its dramatic qualities.

Elections for state officials and for Congressmen were held in Maine and Vermont in September and in Ohio and West Virginia in October. Interest centered in Ohio, as it was a doubtful state, and both parties were anxious to carry it for the moral effect it would have on the November elections. Blaine spent the two weeks preceding the election campaigning in Ohio, devoting his attention, as did most of the Republicans, mainly to the tariff. The Independents sent Carl Schurz to speak for the Democratic candidates. Although the liquor queston was not an issue in the election, it had not yet been satisfactorily settled and it was thought that it would react against the Republicans. Another supposed source of Republican weakness was the great amount of unemployment in the state. The vote resulted

${ }^{1}$ N. Y. World, Oct. 30, 31, Nov. 2; Hudson, op. cit., p. 208; Peck, op. cit., p. 43.

${ }^{2}$ Hamilton, Blaine, p. 588.

${ }^{3}$ N. Y. Tribune, Nov. 4.

${ }^{4}$ Hudson, op. cit., p. 2 Io.

${ }^{5}$ Ibid., p. 212; Hamilton, Blaine, p. 588; Cooper, American Politics, vol. i, p. 319. 
in the election of the Republican state officials by majorities averaging 12,000, and in the election of eleven Democratic and ten Republican Congressmen, a gain of four for the Republicans. Both sides claimed to be encouraged by the result, the Democrats comparing it to the larger majorities received by the Republicans in 1880 , and the Republicans to the Democratic majorities of 1883 . All things considered, the Republicans had more cause for rejoicing. The Democrats charged that unfair tactics had been used by the Republicans, that money had been freely spent and that some of the Democratic papers, especially those of Cincinnati, had not given loyal support to the ticket. ${ }^{1}$ Dudley, the Commissioner of Pensions, resigned his position, the resignation to take effect November Io, and went to Ohio to work for the Republicans. ${ }^{2}$ Congress during the session following the election investigated the election activities of Lot Wright, U. S. Marshal for the Southern district of Ohio. It was disclosed that Wright had appointed I37 I special deputies in the Cincinnati district many of whom were not residents of Ohio. It was charged that the purpose was to intimidate Democratic voters, but no action was taken against Wright. ${ }^{3}$

Nothing unexpected developed in the other early elections. In Maine the Republican governor was re-elected by an increased majority and all the Congressmen were Republican. Vermont, as usual, was strongly Republican, but the total vote was several thousand smaller than in 1880 . the Republican decrease being somewhat larger than that of the Democrats. In West Virginia the fusion between the Republicans and the Greenbackers cut the normal Democratic majority slightly. ${ }^{4}$

1 Ann. Cyc., 1884, p. 63I ; N. Y. papers, Nov. 10-20.

${ }^{2}$ Nation, Oct. 2, I6. $\quad{ }^{3}$ House Rep., 48 C., 2 S., no. $268 \mathrm{I}$.

'N. Y. Times, Sept. I, 6, II ; Ann. Cyc., I884, p. 464. 
Throughout the campaign there was a great deal of laudation by each party of itself for what it had done and a great deal of condemnation by its opponents for what it had not done, but there was a minimum of discussion as to what either party proposed to do. Neither had a definite program of action on any subject to present. ${ }^{1}$ In spite of the poverty of issues, the Independent defection and the attacks on the public and private characters of the candidates made the campaign one of unusual interest and bitterness. As the time for election approached both sides publicly claimed to be confident of success. As a matter of fact, the Republicans apparently were confident, ${ }^{2}$ but the Democrats, with the estimates of Democratic leaders throughout the state before them, saw little chance of carrying New York. ${ }^{2}$ Both sides realized that the election would turn on the results in the four doubtful states, New York, New Jersey, Connecticut and Indiana.

The day after the election the papers of both sides admitted that the election was in doubt but those of each party claimed that their candidate was in the lead. The official returns, so far as they were complete, seemed to favor Cleveland. The Associated Press, which received returns by election districts instead of by counties, claimed that Blaine had won. Florida, Virginia, West Virginia, Michigan, Indiana, Illinois, Nevada and New York were claimed by both parties. By the third day, Friday, it had become apparent that the final result depended on New York and all the leading papers except the New York Tribune conceded Cleveland's election. It was charged that Jay Gould, who controlled the Western Union Telegraph Company, and through it the Associated Press, had been

${ }^{1}$ Vide, e. g. campaign textbooks of both parties.

${ }^{2}$ Letters of Mrs. Blaine, vol. ii, p. I20.

'Hudson, op. cit., p. 206. 
holding up and falsifying the returns in order to manipulate the stock market, and threats of violence were made against him. ${ }^{1}$ Gould telegraphed Cleveland on Friday congratulating him on his election. Saturday morning the Associated Press sent out a report that Cleveland had won. The Tribune still claimed that Blaine had carried New York and did not give up until November I6, when the returns from the official canvass of the votes were available and showed that the plurality of the highest Cleveland elector over the highest Blaine elector was II 49 and that of the lowest Cleveland elector over the highest Blaine elector was 1043. ${ }^{2}$

There were the usual charges and counter charges of fraud and the corrupt use of money. None of these were definite or were ever pressed. The statement that Blaine really carried New York and that he was deprived of his victory by falsification of the returns or by counting Butler ballots for Cleveland, has been made by men of responsible character. $^{3}$ These repeated assertions finally led F. L. Stetson and W. G. Rice of New York, both of whom had taken a prominent part in the campaign and in the count, to publish a reply ${ }^{4}$ in which they seem to prove conclusively that the charge is an empty one. They show that both sides took all possible precautions to insure a fair count. When the closeness of the vote became apparent, telegrams were sent out from Albany in the name of Manning, the state Democratic chairman, to Democrats in every district warning them that the vote was close and asking them to do all

${ }^{1} N$. Y. Times, Nov. 6, 7, 8 .

2 Ann. Cyc., I884, p. 585; N. Y. papers, Nov. 5-16; Nation, Nov. I3; Harper's Weekly, Nov. I5; Hamilton, Blaine, p. 588; Hudson, op. cit., p. 220.

${ }^{3}$ Stanwood, Blaine, p. 29I, also article in Atlantic Monthly, Oct. I912; Hoar, Autobiog., vol. i, p. 408.

* North American Rev., Jan., I914; also reprinted as a pamphlet. 
in their power to insure a fair count. A committee of Democratic and Independent lawyers was formed in New York city to advise on any legal questions that might come up. The Republicans had representatives on every election board and had responsible men present at the official count in each county. Mr. Stanwood admitted that his accusation was based on suspicion rather than on fact, and it was shown that all the Cleveland votes in Long Island City, where Senator Hoar charged that Butler votes were counted for Cleveland, were not sufficient to have changed the final result.

Beside the solid South, Cleveland carried New York, New Jersey, Connecticut and Indiana. In I880 Hancock had carried only New Jersey, Nevada and California in addition to the sixteen southern states. Beside carrying California and Nevada, Blaine received greatly increased pluralities over those of Garfield in Pennsylvania and Maine and slightly increased ones in Colorado, Minnesota, Nebraska, New Hampshire and Oregon. In the other states carried by him his pluralities were lower than those of Garfield. ${ }^{1}$

Butler's vote was over forty-three percent less than that of Weaver in I88o. It was noticeable that, except in Michigan, where he gained 8,000 votes, Butler's losses were mainly in the West. In the industrial states of the East he nearly equaled Weaver's vote and in some cases exceeded it. In Massachusetts his personal following increased his vote to 24,443 as compared to Weaver's 4,548 .

St. John polled 150,369 votes, an amazing total as compared with the 10,305 received by Neal Dow, the prohibition candidate in I88o. St. John received more than four percent of the total vote in Michigan, more than three percent in Massachusetts and more than two percent in New York,

${ }^{1}$ Stanwood, Presidency, pp. 417, 448. 
New Jersey, Rhode Island, Vermont, Kansas, Nebraska and Minnesota. His largest votes came in states where there had been considerable agitation on the temperance question or where the Independent movement was strong.

In the Congressional elections the Democrats lost sixteen seats in the House, reducing their plurality of eighty-one over the Republicans in the forty-eighth Congress to fortyfive in the forty-ninth. The Republicans gained two seats in Indiana, three in New York, four in Pennsylvania, four in Ohio and five in California. The Republicans retained control of the Senate. ${ }^{1}$

The question of just why voters vote as they do involves a complex study in political psychology and is one that probably a majority of voters could not answer satisfactorily for themselves. The Independent movement, the strength of the Prohibitionists, the lukewarmness of the Stalwarts, the unfortunate remark of the Rev. Mr. Burchard, have all been given as reasons for Cleveland's election. Blaine himself declared that the suppression of the Republican vote in the South made it necessary for the Republicans to carry New York, and that New York was lost through the strength of the Independents and Prohibitionists and through the remark of Burchard. ${ }^{2}$ When we consider that if Cleveland had lost New York, or that if he had lost Indiana and either Connecticut or New Jersey, Blaine would have been elected, and that Cleveland's plurality in New York was only I I 49 out of a total vote of more than $1,150,000$, in Indiana 6527 , in Connecticut 1276 , and in New Jersey $435^{8}$, it is evident that any one of the above mentioned incidents may have been decisive. All of them undoubtedly worked toward the same end, though with varying degrees of effectiveness.

${ }^{1}$ McPherson, 1886, pp. I, 30.

${ }^{2}$ Blaine's Political Discussions, p. $464 ;$ N. Y. Tribune, Nov. 17, 1884. 
Foremost among these causes contributing to Blaine's defeat must be placed the revolt of the Independents. They claimed full credit at the time, ${ }^{1}$ and writers who had no sympathy for the movement and who have no use for independents in general have since paid tribute to their strength. $^{2}$ They claimed to have polled 60,000 votes in New York, 20,000 in Ohio, 40,000 in Massachusetts, 5,000 in Connecticut, 15,000 in New Jersey, I0,000 in Indiana and 20,000 in Illinois. ${ }^{3}$ These estimates are undoubtedly generous, but the significant fact is that the Independents were strongest in the doubtful states where Blaine could least afford to lose votes. It is probable that a large number of Republicans would have supported Cleveland in any case, but the organized campaign of the Independents must have materially increased this number.

The main article in the Independent creed was that the affairs of the government be conducted in an honest, efficient and economical way. The first step toward the goal of good government was, they believed, the reform of the civil service, which would hasten the elimination from public life of the machine politician who worked only for the interest of party or self and discouraged intelligent participation in politics. The Independents fully accepted the current philosophy as to the rights of private property and the proper relations between the government and business interests. They insisted, however, that this relation should be open and above board, that the government treat all impartially. There must be no secret understandings between government officials and private interests.

${ }^{1}$ N. Y. Times, Evening Post, Nov. 5, 6; Nation, Nov. 13; Harper's Weekly, Nov. 15; Report of Ind. Ex. Com. passim.

2 Leslie's Hist. of Rep. Party, p. 444; Curtis, Republican Party, vol. ii, p. 484 .

Report of Indep. Ex. Com., passim. 
The political situation was particularly favorable for an Independent movement in I884. In times when great principles are at stake the choice between them cannot be complicated by too careful consideration of the methods by which these principles are to be made effective. When, however, there are no real differences in principle between parties the question of methods becomes of prime importance. As long as there was a question of the overthrow of slavery, of preserving the Union, or of maintaining what had been accomplished by the war, many voters unhesitatingly supported the Republican party, although they were repelled by the character of some of its leaders and by the inefficiency and corruption that had developed within it. They would have supported the party in 1884 , in spite of their disgust with its methods and distrust of its candidate, had there been any real issue between it and its opponents. The fact that both parties were in practical agreement as to national policy made the question of how this policy was to be carried out the all-important one, and this depended, in the opinion of many, on the character of the chief executive.

To the Independents Blaine was the embodiment of all that they liked least in politics. Throughout his career he had been a spoilsman rather than a civil service reformer. As a party leader in his state and in the nation, and even as a candidate for the Presidency, he had associated himself with many politicians of the worst type. His popularity had been to a large extent artificially developed and was the result of skilful appeals to the emotions rather than of a reasoned conviction of the importance or the righteousness of the causes which he had championed. Above all, he had never been able to convince a large number of people that he had not used his public office for his own private ends or that he would not do so again if given the opportunity.

In spite of Blaine's weakness with the Independents, he 
had great elements of strength and it must not be assumed that another candidate would have been more successful. To the rank and file of the Republican voters who got their opinions on politics ready-made from partisan papers and who had little patience with what they considered to be the hair-splitting of political purists, Blaine was the "plumed knight," the bold, dashing, magnetic statesman who had been foully slandered by envious enemies. It is hardly fair to compare Blaine's vote with that of Garfield in I880, for in the meantime the Republican party had experienced a general decline. In I 882 the Democrats had carried Pennsylvania, Massachusetts, Michigan, Illinois, Kansas, Colorado, Nevada and California, and although there had been slight gains for the Republicans in 1883 , few Republicans could have duplicated Blaine's feat in bringing all these states back into line in I884. In several states, notably Illinois and Michigan, the Republican electoral ticket ran well ahead of the state and local tickets. ${ }^{1}$ A circumstance which hurt Blaine and would have hurt any Republican in 1884 was the existing business depression and the large amount of unemployment that went with it. Whether with reason or not, business depression and unemployment are always likely to react unfavorably on the party in power, especially when there are no great issues to distract attention from them. Business stagnation was one of the causes of the Republican reverses in 1882 and conditions had grown steadily worse since that time.

$$
{ }^{1} \text { N. Y. Tribune, Nov. I4. }
$$




\section{CHAPTER XI}

\section{The Democrats in Power}

THE election of Cleveland was an experiment. Could a man with absolutely no experience in national affairs, however good his intentions, satisfactorily perform the functions of President of the United States? Could a group dissatisfied with conditions in its own party join hands with its opponents and force its program on them with any hope of success? Finally, could a party made up in large part of individuals who had attempted or connived at an attempt to destroy the state be trusted to administer the affairs of that state, however much the ideas and ideals of those individuals might have been modified? These were the questions which the Democratic administration had to answer.

Neither Democrats nor Republicans knew just what to expect. The return of the Democrats to power had not been a manifestation of approval of any particular policy, for the party, as a party, had no policy. To some Democrats a return to power meant nothing more than safety from negro and carpet-bag domination, to others it meant tariff reform, to others silver coinage. ${ }^{1}$ A large part of the population of the North had been brought up to believe that a return of the Democrats to power would mean business disaster, derangement of the finances, debasement of the currency, annullment of the war amendments, repudiation of the national debt, payment of the rebel debt, pension. ing of Confederate veterans and reënslavement of the

${ }^{1}$ Cf. Schurz, Works, vol. iv, p. 440, letter of Bayard; Nation, Jan. I4, 1886. 
negro. ${ }^{1}$ There could be no real discussion of policies, no real argument on issues until the Democrats had proven the foolishness of these ideas. The first task of the Democrats was the negative one of convincing the country that on the fundamental principles of the government they were as worthy of trust as their opponents. They might then go on to formulate their policies and present them to the country on their merits.

On this negative side the Democrats were successful. Cleveland's inaugural address might easily have been endorsed by any Republican. His cabinet in ability and integrity compared favorably with any of those of his Republican predecessors. No commercial or industrial disaster materialized. On the contrary business was good and showed a steady improvement over the previous four years. ${ }^{2}$ The payment of the national debt went steadily on; the rebel debt was not paid; the negroes were not reënslaved. Events proved that the "results of the war" were as safe in Democratic as in Republican hands. Cleveland declared in his inaugural address that, "All discussion as to their [the negroes'] fitness for the place accorded them as American citizens is idle and umprofitable except as it suggests the necessity for their improvement," ${ }^{3}$ and there was nothing in his official acts that belied this statement. There were some attempts on the part of the Republicans to stir up the sectional issue: one when the south enthusiastically applauded speeches of Jefferson Davis at Montgomery and Atlanta in I 886 glorifying the rebellion; another when Cleveland issued an order for the return to the states of all flags captured during the war, an order which was later rescinded on the

${ }^{1}$ Nation, July 5, I888.

${ }^{2}$ Com. and Fin. Chronicle, Jan. 9, I886, Jan. 8, I887, Jan. 7, r888.

${ }^{3}$ Richardson, vol. viii, p. 302. 
ground that he had exceeded his powers in issuing it. Neither of these events attracted much attention, however, except from the professional patriots. ${ }^{1}$ One practical difference that a Democratic administration did make to the South was that there was no threat of interference by federal officials in Congressional elections. Another was that many southern Democrats, among them several that had served in the Confederate army, were appointed to federal office. $^{2}$ The Democratic office-holders, northern as well as southern, proved that they were much like their Republican fellow citizens,--some of them good, some bad, some indifferent.

What looked like an attempt to stir up sectional animosity was the attack on Cleveland's pension policy. More careful scrutiny of claims in the pension office and the consequent greater number of rejections led to a large number of special pension bills. Cleveland used his veto freely on these bills and took occasion in his veto messages to show that many of the claims were ridiculous. ${ }^{3}$ In January, I887, Congress passed a dependent pension bill which provided a pension of twelve dollars per month for all veterans who had served at least three months and were unable to support themselves. Cleveland vetoed this bill on the ground that its provisions were vague, that there was no actual knowledge as to its cost and that it pauperized the veterans and made the pension list which should be a roll of honor a retreat for the dishonest. ${ }^{4}$ Republican papers declared that this veto was a direct insult to Union veterans and an attempt to curry favor with the South. They pointed out that Cleveland had signed a bill granting pensions to all dependent

${ }^{1}$ Public Opinion, June 8, I886; Peck, Twenty Years, p. I44.

${ }^{2}$ Nation, June II, I885.

${ }^{3}$ Richardson, vol. viii, p. 443 et passim.

I Ibid., p. 549. 
veterans of the Mexican war, ${ }^{1}$ presumably because this bill provided for southerners as well as northerners. ${ }^{2}$ The New York State Republican platform of 1887 condemned the "flippant, sneery language of the President in vetoing pension bills." "Some of the officials of the Grand Army of the Republic were very bitter against Cleveland and were so successful in stirring up feeling against him that he withdrew his acceptance of an invitation to address the encampment at St. Louis in 1887 . The organization, however, refused to pass a vote censuring Cleveland or to endorse a general dependency pension bill. ${ }^{4}$ Public opinion on the whole supported Cleveland in his pension policy. ${ }^{5}$ The fact that in spite of vetoes, appropriations for pensions grew steadily from sixty millions in I886 to eighty-one millions in I889 would seem to indicate that the veterans were not being neglected.

Financial interests had been inclined to distrust the Democrats because of the soft-money tendencies of a large section of the party. In 1885 the unwillingness of the country to use the silver dollars whose coinage was compulsory under the Bland act was causing silver to pile up in the treasury and imperiling the gold reserve. Cleveland made it clear from the start that he was as strong a champion of hard money as any Republican. Before his inauguration in an open letter to members of the forty-eighth Congress he condemned continued silver coinage ${ }^{6}$ and in his first message to Congress he declared that currency reform through suspension of silver coinage was the most important question before the country. ${ }^{7}$ He could not get much support for

${ }^{1}$ U. S. Stat. at Large, ch. 70, 1887. $\quad{ }^{2}$ Public Opinion, Feb. 19, 1887.

${ }^{3}$ Ann. Cyc., I887, p. 552.

4 N. Y. papers, Oct. I, I887; Dewey, National Problems, p. 82.

${ }^{5}$ Nation, July 14, I887; Public Opinion, Feb. 19, I887.

${ }^{6} \mathrm{McPherson,}$ I886, p. II6.

${ }^{7}$ Richardson, vol. viii, p. 342. 
his ideas, however, from either party in Congress and no action was taken. The increased demand for currency due to expanding trade, the withdrawal of bank notes with the redemption of bonds and the expedient hit upon by the treasury of issuing silver certificates of small denominations and replacing greenbacks with them, all helped to force more silver into use and to relieve the drain on the gold reserve so that the threatened disaster did not materialize. ${ }^{1}$ In April, r886, ninety-six Democrats and thirty Republicans in the House voted for free coinage of silver, while seventy Democrats and ninety-three Republicans voted against it. $^{2}$ On July I4, I886, a resolution calling on the Secretary of the Treasury to purchase bonds whenever the balance in the Treasury should exceed $\$ 100,000,000$ passed the House by a vote of 209 to 146 . Although the effect of this resolution would be to force the payment of bonds in silver, sixty-three Republicans were recorded with the majority. ${ }^{3}$ Neither party could as yet make the currency question a test of party orthodoxy but it was evident that hard-money adherents had little more to fear from the Democrats than from the Republicans, at least as long as Cleveland was President.

One other negative accomplishment of the Democrats was the fact that there were no big jobs or scandals during Cleveland's 'term. Appropriations increased gradually, it is true, but in spite of an overflowing treasury there was evidence of an intention to keep expenditures within reasonable bounds. Cleveland refused to sign the rivers and harbors bill of I887 and vetoed the bill passed in December I 888 to return to the states the direct tax of $186 \mathrm{I}$, declaring it to be a "bald gratuity". The nearest approach to a

1 Noyes, Forty Years of American Finance, p. 104.

${ }^{2}$ McPherson, 1886, p. 100.

${ }^{3}$ Nation, July 22, I886; Public Opinion, July 24, 1886.

' Richardson, vol. viii, p. 837. 
scandal was the implication of Attorney General Garland in the Pan Electric affair. Garland caused, or at least allowed, a suit to be brought by his department attacking the validity of the Bell Telephone Company's patent, a suit which if successful would greatly increase the value of Pan Electric stock, of which he was a large holder. The propriety of his action was sufficiently questionable to give Republicans in Congress and Republican newspapers a chance to declare the administration disgraced, but Democrats and independents generally refused to see anything improper in it. ${ }^{\text {' }}$

On the question of civil service reform the Democrats had both a negative and a positive task. The public sentiment for reform was weak and vague, but there was enough of it to make disastrous for the party any complete repudiation of what had been accomplished. On the other hand, if the Democrats wished to make reform an issue, to be known as a reform party, they must do much more than acquiesce in what had been clone. The fact that Cleveland had committed himself to civil service reform on various occasions by his actions as well as his words was one of the main factors in gaining him the support of the Independents and they naturally expected and demanded not only faithful execution of the law but an extension of the principle. The great majority of the leaders of the Democratic party, however, had no sympathy with reform. They had accepted Cleveland because they realized the necessity for Independent support, but they had no idea of making their party a reform party. While many of the Republican leaders professed to be ardent champions of reform, there was scarcely one among them who would not put partisan advantage above promotion of the idea. The personnel of the civil service was not satisfactory. It had been built up

1 House Rep., 49 C., I S., no. 3142; Public Opinion, July Io, 1886. 
for a quarter of a century on the principle that only Republicans should be appointed to office and they on the basis of partisan service rather than ability to perform the functions of the office. Many office-holders were inefficient and many would have no scruple against using their office to discredit a Democratic administration. Cleveland's task was, then, to remodel the service into one that would be efficient and non-partisan and to do this in a way that would satisfy the reformers, would not disrupt his own party and would not give the Republicans ground for attack.

Cleveland's attitude toward the civil service during the early months of his administration gained the hearty approval of the reformers. Although some of his appointments were criticized, in the main they were good, removals were comparatively few, some Republicans were appointed and others were retained after their terms expired. ${ }^{1}$ George W. Curtis in his presidential address before the National Civil Service Reform League in August, I885 said:

Any unprejudiced observer, Republican or Democrat, who considers the enormous difficulties and perplexities of the situation .. . will admit that since the spoils system was first generally introduced into our national administration no President has given such conclusive evidence both of his reform convictions and of his courage in enforcing his convictions as President Cleveland. ${ }^{2}$

Cleveland soon found, however, that the path of a reformer was by no means a smooth one. The pressure upon him from members of his own party to make a "clean sweep" of Republicans was tremendous. Many Democrats who claimed to be for reform interpreted reform to mean

${ }^{1}$ Nation, July 2, 23, Aug. 6, 13, I885, Feb. 4, 18, 1886; Schurz, Works, vol. iv, p. 367 .

${ }^{2}$ Curtis, Orations and Addresses, vol. ii, p. 300. 
replacing partisan Republicans by "good" Democrats. ${ }^{1}$. Every appointment that Cleveland made which gained the approval of the Independents brought down upon him a chorus of condemnation from members of his own party. ${ }^{2}$. Cleveland had to depend often on the advice of Democratic Congressmen as to removals and appointments and he was frequently deceived. Many of his subordinates in the executive departments had no real sympathy with his ideas. Congress obstructed rather than helped. In the first session of Congress during his administration two bills were introduced by Democrats for the repeal of the civil service act, one in the House by Seney of Ohio and the other in the Senate by Vance of North Carolina. ${ }^{3}$ Both of these bills were reported adversely, but in neither case was the committee unanimous. ${ }^{4}$. More dangerous than the direct attacks on the statute were proposals to amend it in such a way as to deprive it of much of its force. Among these proposals the most important was an amendment offered by Randall to an appropriation bill which provided that the names of all applicants found to be qualified should be reported to appointing officers, - the effect being to make the examination a mere pass examination instead of a competitive one. This was defeated on a point of order but another amendment of Randall's, which took I 50 places in the pension office out from the provisions of the statute by means of a reclassification, was adopted. ${ }^{5}$

The remarks of Vance in support of his bill, which were applauded in the Senate and quoted approvingly by several

${ }^{1}$ N. Y. Sun, March 15, I885; J. B. Eustis, in North American Rev., Oct. 1885 .

${ }^{2}$ N. Y. Sun, Nov. 28, 1885; Public Opinion, April 24, 1886.

${ }^{3}$ Cong. Rec., 49 C., I S., pp. 40I, 464.

${ }^{4}$ Ibid., p. 2287; House Rep., 49 C., I S., no. roor.

${ }^{5}$ Cong. Rec., 49 C., I S., p. 5489; Curtis, op. cit., p. $3^{12}$. 
Democratic newspapers, may be taken as an indication of the attitude of a large part of the party toward reform. Vance said:

No more unmistakable sign of the decay of public virtue in politics has been furnished by American history than the rise ... of that maudlin political sentiment which we recognize for want of a better, under the name of "Mugwumpism", a kind of sickly, sentimental, Sunday-school, "Goody TwoShoes" party, which appears desirous of ruling the world not as God has made it, but as they would have it. ${ }^{1}$

Democratic state platforms in 1886 and I887 while endorsing Cleveland's administration entirely ignored in most cases the question of civil service reform or gave it but perfunctory endorsement. In 1887 the New York Democrats renominated Hill, who had openly flouted reform, and declared in their platform that "In view of the radical changes in the administrative methods which grow out of the civil service laws and the difference of opinions which exist in relation thereto, we deem this subject one which might properly be submitted to the popular vote." 3 In the Congressional elections of 1886 the Democrats retained a majority in the House but lost fifteen seats, a result which the spoils papers were almost unanimous in declaring was due to Cleveland's "civil service nonsense." "

This pressure upon Cleveland from his own party had its effect. Removals became more frequent and since usually no reasons were given it was assumed that they were made from purely partisan considerations. Senator Hale in an attack on the administration in the Senate gave figures show-

${ }^{1}$ Cong. Rec., 49 C., I S., p. 2946.

${ }^{2}$ Ann. Cyc., 1887, passim.

${ }^{3}$ Ibid., p. 552.

${ }^{4}$ N. Y. Sun, Nov. 7, 10, 1886; Public Opinion, Nov. 6; Nation, Nov. II. 
ing that up to June I887, out of 56,134 more important officials who controlled others and whose change meant the change of others, 42,992 had been removed. ${ }^{1}$ George W. Curtis said in his address before the National Civil Service Reform League in August I887 that "almost as complete a change as was possible" had been made. ${ }^{2} \quad$ Cleveland seemed to have determined upon a sort of local option on the civil service question. Where there was considerable reform sentiment, as in New York and parts of New England, the appointments were usually good and removals comparatively infrequent; where there was a strong Democratic organization and little reform sentiment removals and poor appointments were common. Conditions in Indiana and Maryland were particularly bad, calling forth protests from reformers and reform organizations. It was charged that in these states and also in the Philadelphia post office the civil service law was systematically evaded. ${ }^{3}$

Cleveland came into conflict with the Senate on the question of removals. Committees of the Senate from time to time requested from heads of departments papers showing causes for removals. On advice of the President these requests were refused. Several nominations were held up, it being intimated that if there was a frank avowal that removals were made for purely partisan reasons, ratification would follow without further ado. ${ }^{4}$ The question came to a head when Attorney General Garland refused the request of the senate judiciary committee for papers in regard to the removal of a Republican district attorney for the southern district of Alabama. After Cleveland had sent a special

${ }^{1}$ Cong. Rec., 50 C., I S., p. 373.

${ }^{2}$ Curtis, op. cit., p. 342.

${ }^{3}$ Sen. Rep., 50 C., I S., no. 2373, passim ; Foulke, Fighting the Spoilsmen, chap. iii ; Nation, July 28, I887, March 7, I889.

${ }^{4}$ Cleveland, Presidential Problems, p. 42. 
message justifying his refusal to submit papers ${ }^{1}$ and the Senate had adopted resolutions condemning the Attorney General, declaring it to be their duty to refuse ratification in any case where papers were not submitted and condemning the removal of Union veterans, the matter was dropped. The sympathy of the public was with Cleveland in the dispute; for it was quite clear that the Senate was acting from partisan motives.

Schurz wrote Cleveland early in his administration that if he tried to please both Democrats and Independents by his civil service policy he would be in danger of "sitting down between two chairs. ${ }^{2}$ This was practically what Cleveland did; for although his yielding to the Democrats did not satisfy them, it alienated many of his Independent supporters. The Independents were ready to give Cleveland credit for the good accomplished but they were extremely critical of any lapses.. Cleveland resented these criticisms, feeling that the reformers did not appreciate the difficulties of his position. He was particularly jealous of his independence. The charges made during the campaign that his inexperience in politics would result in his being a puppet of the more experienced politicians heightened this feeling. He resented anything that remotely resembled interference in his own affairs whether it came from members of his own party or from the Independents. ${ }^{4}$ Schurz, whose advice Cleveland had at first welcomed, ${ }^{5}$ complained that after he had criticized certain appointments his letters to

${ }^{1}$ Richardson, vol. viii, p. 375 .

'Schurz, Works, vol. iv, p. 402.

'Ibid., pp. 317, 405, 414; Nation, July 23, Aug. 13, I885.

'Peck, Twenty Years, p. I59. Tilden complained that a recommendation from him was enough to ensure a request being denied. Bigelow, Tilden, vol. ii, pp. 306, 316.

${ }^{5}$ Works, vol. iv, p. 297. 
the President remained unacknowledged. ${ }^{1}$ In a letter of September I I, I885, accepting the resignation of Dorman B. Eaton as a member of the civil service commission, Cleveland spoke disparagingly of those

who profess friendliness for the cause, and yet mischievously and with supercilious self-righteousness, discredit every effort not in exact accord with their attenuated ideas, decry with carping criticism the labor of those actually in the field of reform, and ignoring the conditions which bound and qualify every struggle for a radical improvement in the affairs of government, demand complete and immediate perfection. ${ }^{2}$

In his special message of July 23, I888, submitting the report of the civil service commission to Congress he said: "The path of civil service reform has not at all times been pleasant nor easy... both friends and enemies have misunderstood and complained." 3

On July I4, I 886, Cleveland issued an executive order warning office-holders against activity in politics. "Individual interests and activity in political affairs are by no means condemned," he said, "but privileges are not enlarged by . . . office holding." " In pursuance of this order he removed during the Congressional campaign of the following fall two district attorneys, one a Republican the other a Democrat, for partisan activity. He later brought down upon himself a storm of protest from Republicans and Independents when he restored the Democrat to office but refused to restore the Republican. Schurz declared in a letter to Cleveland, "This was a retreat from a position of principle- - backdown, apparently for partisan reasons or under partisan dictation." ${ }^{5}$

1 Works, vol. iv, pp. 437, 475.

${ }^{3}$ Richardson, vol. viii, p. 618.

${ }^{5}$ Schurz, Works, vol. iv, p. 469.
${ }^{2} \mathrm{McPherson,}$ I886, p. II7.

"Ibid., p. 494. 
Although the Independents were disappointed with Cleveland's civil service record. the majority of them were willing to concede that his position had been a most difficult one and that the reform had been advanced. The Nation said: "Mr. Cleveland has in the matter of civil service reform fallen far short of his promises, he has as a matter of fact done far more for it than any of his predecessors." ${ }^{1}$ Har per's Weekly said: "If reform in the civil service has failed to receive from him the support which had been expected... those who best know the situation are least harsh in their censure... they have not questioned and do not doubt his honesty of purpose, his sincerity of conviction or the actual progress in reform which has been accomplished." ${ }^{2}$

Cleveland's success in converting the Democratic party into a reform party was not conspicuous. Some of the spoils papers, particularly the New York Sun, were inclined to boast that he had yielded on the question. ${ }^{3}$ In the Democratic national platform of I888 the only mention of the subject was a casual allusion to "honest reform in the civil service" in the list of the accomplishments of Cleveland's administration. ${ }^{4}$ Nevertheless Cleveland's feat of keeping the reform principle alive and the same time retaining the support of his party to such an extent that they renominated him without a contest, was no small one.

The Republicans made the most of the opportunity that Cleveland's lapses gave them to show the insincerity of all Democratic talk of reform. The most charitable among them said that Cleveland had probably done as well as his party would let him do. ${ }^{5}$ Others asserted that his adminis-

${ }^{1}$ June I4, I888; vide also Nation of Oct. 25, 1888, and March 7, 1889.

${ }^{2}$ Nov. I7, I888; vide also N. Y. Times, Nov. 4, 9, 1888.

${ }^{3}$ July 2, 7, Oct. 30, I888.

${ }^{4}$ Stanwood, Presidency, p. 469 ; vide also N. Y. World, June 7, 1888.

${ }^{5}$ Roosevelt in North American Rev., Oct. 1885. 
tration had been an orgy of spoils. ${ }^{1}$ The Republican members of the Senate committee on civil service after an investigation reported that many partisan changes had been made, that there had been wholesale removals of Union soldiers, and that federal officials had freely and openly participated in politics. ${ }^{2}$

Any fair estimate of the civil service record of the Democrats must be based on a consideration of conditions as they existed, not on any theory as to the necessity for or the practicability of reform. Civil service reform could not be put into effect by the enactment of a statute or by a Presidential proclamation. It required a long process of education. Cleveland realized this and attempted to lead public sentiment step by step. If his steps seem slow and faltering it must be remembered that a reform of the civil service was not the only thing he hoped to accomplish. The fact that the whole idea of reform was not repudiated, that the law, as it went, was fairly well enforced, was in itself a negative gain for the Democrats. There was even some positive accomplishment. The competitive principle was applied to promotions by an executive order of May, I887 and in March, I889 the law was extended to the railway mail service. $^{3}$ By this later extension and by the application of the law to additional postoffices and customs houses as the number of their employees reached fifty, the number of persons under the provisions of the law was raised from about 14,000 to over 28,000 during Cleveland's term. ${ }^{4}$ His administration may fairly be called a period of progress in civil service reform,--slow indeed, but still progress.

${ }^{1} \mathrm{H}$. C. Lea, in Independent, Oct. I8, 1888; vide also Indep., Oct. 25, Nov. I, 8 , and N.Y. Tribune, Nov. 4,8 .

${ }^{2}$ Sen. Rep., 50 C., I S., no. 2373.

${ }^{3}$ Richardson, vol. viii, pp. 572,845 .

${ }^{4}$ Report Civ. Ser. Com., I889. 
That it was even slow progress was due, as far as official action is concerned, to Cleveland's personal efforts. There was in Congress no member of their party who was an active worker for the reform.

The question which more than any other has attracted attention to Cleveland's administration is that of the tariff. The attempt at tariff reduction, the lack of harmony in the Democratic party on the question and the attitude of the two parties during the Presidential campaign of 1884 have already been told. ${ }^{1}$ It will be remembered that both parties while accepting the principle of protection had pledged themselves to reduce the tariff. It was the surplus revenue that led both parties to take this stand and it was the continued surplus that kept the question in the foreground. In spite of steadily increasing expenditures and in spite of the redemption of bonds to the amount of $\$ 195,000,000$ above the requirements of the sinking fund, business prosperity with increased consumption and increased imports ${ }^{2}$ kept the surplus continually mounting. The surplus for the fiscal year I 886 was ninety-three millions and for the three following years I03 millions, I I9 millions and I05 millions respectively. The unexpended balance in the treasury on June 30 , I885, was $\$ 521,000,000$ and on June 30 , I 889 $\$ 659,000,000 .^{3}$

Cleveland from the start gave evidence of his intention to live up to the pledges of his platform. In his inaugural and in his first message to Congress he pointed out the necessity for reducing taxes as the logical means of reducing the surplus. "The question of free trade is not involved," he said in his message of December, 1885, " nor is there now any occasion for the general discussion of the wisdom or expediency of the protective system." ${ }^{4}$ His first Congress

1 Vide supra, pp. II6 et seq., 215.

${ }^{3}$ U. S. Stat. Abst., I889, p. 2.
2 Noyes, op. cit., p. II3.

- Richardson, vol. viii, p. 34I. 
did nothing with the tariff. Neither party appeared to take its platform seriously. A large majority of the Democrats were in favor of reduction but a group of protectionists under the leadership of Randall were able by combining with the Republicans to prevent action. A tariff bill introduced by Morrison, chairman of the ways and means committee, which reduced duties and increased the free list, was killed June 17 , I886, by a vote of 140 to 157 , thirtyfive Democrats voting with the majority. ${ }^{1}$ Randall then introduced a bill which, it was estimated, would reduce internal revenues by $\$ 26,000,000$ and customs by $\$ 8,000,000$ but it was reported unfavorably by the ways and means committee. $^{2}$

The Democratic state platforms of 1886 in general followed the formula of the national platform of 1884 on the tariff. A few made stronger demands for reduction, Indiana declaring that taxation for any other purpose than revenue was robbery under the form of law and Missouri that any other than a revenue tariff was unconstitutional. California Democrats, however, demanded the restoration of the duty of 1867 on wool. The Republican platforms showed a stronger protectionist tone than previously, many demanding that the principle of protection be maintained and others attacking the Morrison bill as a step toward free trade and a blow at American workingmen. ${ }^{3}$ The Republican papers pretended to see in the results of the election, which reduced the Democratic majority in the House from forty-five to seventeen, and especially in the defeat of Morrison, a mandate against tariff reduction." Tariff reformers insisted that the tariff played little part in

${ }^{1} \mathrm{McPherson,} \mathrm{1886}$, p. 156.

IIbid., p. 157.

3 Platforms in Ann. Cyc., 1886.

${ }^{4}$ N. Y. Tribune, Nov. 4, 6, 1886. 
the campaign. ${ }^{1}$ Whatever the mandate was, Cleveland urged reduction more strongly in his message to Congress in December, I886. Although he based his argument mainly on the surplus, he declared that labor and the farmers were becoming suspicious of the benefits they gained from high duties and characterized the taking by taxation of more than was necessary for the needs of the government as " a violation of the fundamental principles of a free government." 2 Congress was still obdurate, however, and twenty-six Democrats joining with the Republicans prevented consideration of tariff bills by a vote of $\mathrm{I} 54$ to $148 .^{3}$

It was plain that strenuous measures were necessary if the Democratic party was to be united on any tariff policy. Cleveland boldly proceeded to take such measures by devoting his entire message of December, 1887 , to the question of the tariff. He began by pointing out the necessity for immediate action in regard to the surplus. Payment of the three-per cent bonds which were redeemable at the option of the government had furnished an outlet for the surplus but this relief was no longer possible as all such bonds had been redeemed. He expressed doubt as to the power of the Treasury to purchase bonds in the open market. The proposition to deposit money in the national banks he characterized as objectionable on the ground that it gave rise to charges of favoritism and brought about undesirably close relations between the Treasury and the business of the country. $\mathrm{He}$ declared that there was no complaint against the internal revenue taxes and that they laid no hardship on any part of the people, but that the tariff laws were "the vicious, inequitable and illogical source of unnecessary taxation." He then proceeded to attack some of

${ }^{1}$ N. Y. Times, Nov. 5, 1886.

${ }^{2}$ Richardson, vol. viii, p. 509.

${ }^{3} \mathrm{McPherson,} \mathrm{I888,} \mathrm{p.} 52$. 
the stock arguments for protection. He declared that in most cases it was a question of insuring to manufacturers not " moderately profitable returns" but "immense profits." $\mathrm{He}$ asserted that the tariff raised the cost of living to the entire country, that the only persons who could possibly be benefited were the $2,623,089$ employed in protected industries and that their supposed gain was nullified by the increased cost of the commodities that they had to purchase. Competition which might keep down prices was prevented, he asserted, by trusts. He repeatedly declared that it was not a question of doing away with the protective system,for example :

In a readjustment of our tariff the interests of American labor engaged in manufacture should be carefully considered, as well as the preservation of our manufactures. It may be called protection or by any other name, but relief from the hardships and dangers of our present tariff laws should be devised with especial precaution against imperiling the existence of our manufacturing interests.

\section{And again :}

Our progress toward a wise conclusion will not be improved by dwelling upon the theories of protection and free trade. This savors too much of bandying epithets. It is a condition which confronts us, not a theory. Relief from this condition may involve a slight reduction of the advantages which we award our home production, but the entire withdrawal of such advantages should not be contemplated. The question of free trade is absolutely irrelevant. ${ }^{1}$

The message focused the attention of the entire country on the tariff. Democratic and independent papers in general expressed hearty approval, although a small part of the

${ }^{1}$ Richardson, vol. viii, p. 580. 
Democratic press was inclined to question the wisdom of forcing the issue too strongly and to urge the reduction of internal revenues before attacking the tariff. Several Republican papers, among them the Chicago Tribune, the Providence Journal and the St. Paul Pioneer Press endorsed the message. The majority of the Republican papers, however, attacked the message as an argument for free trade. ${ }^{1}$ To characterize every scheme for tariff reduction as free trade or as a step toward free trade became the Republican policy from this time on.

Roger Q. Mills of Texas was appointed chairman of the House ways and means committee of the fiftieth Congress and on April 2, 1888, he reported a bill for the reduction of taxation. The bill provided for the repeal of all taxes on tobacco and its sale except those on cigars, cigarettes and cheroots. The estimated reduction in the internal revenue was $\$ 24,000,000$ and in the tariff $\$ 53,000,000-\$ 31,000,000$ by reduced rates and $\$ 22,000,000$ by additions to the free list. Wool, wood, salt, hemp, flax and tin plate were the principal additions to the free list. The reductions were general, the largest affecting woolen goods and materials made from hemp and flax on the theory that free raw materials made possible lower rates on the manufactured articles. Rates on sugar were reduced an average of twenty percent, the estimated reduction being $\$$ I I,000,000. ${ }^{2}$

The majority report dwelt primarily on the need for reducing the revenue, but also declared that the enactment of the bill would encourage manufacture by stimulating foreign trade. The report asserted that the committee had kept in view at all times "the interests of the manufacturer, the laborer, the producer and the consumer," and admitted

${ }_{1}$ Public Opinion, Dec. 12 ; Nation, Dec. $22 ;$ N. Y. Sun, Times, Tribune, World, Dec. 7-12, I887.

${ }^{2}$ House Rep., 50 C., I S., no. 1496. 
that the bill did not " depart from precedent that tariff legislation has been based on the principle of mutual concession." In his speech introducing the bill Mills pointed out that it reduced the average rate on dutiable articles to forty percent, which was practically the same as that of the Morrill tariff of 186I and not lower than that recommended by the tariff commission of $1883 .^{1}$

The minority of the committee attacked the bill as an avowedly political measure which, "with the President's free-trade message," was to constitute the issue and be the platform of the party. They declared the bill to be a " radical reversal of the tariff policy of the country" and asserted that it would " disturb every branch of business . . . retard ... prosperity and seriously impair our industrial independence." They declared that it would by stimulating imports increase rather than reduce the surplus and insinuated that the President had purposely created the crisis by refusing to buy bonds in the open market. They attacked the majority for not having held hearings on the bill and asserted that the minority had been excluded from any share in framing the schedules. Finally they asserted that it was a sectional measure which protected the iron ore of Alabama and Tennessee but not the steel of Pennsylvania, which protected Louisiana sugar and South Carolina rice but not the products of Republican states."

Debate on the bill began in the House April I 7 and continued with some interruptions until the final vote on July 2I. The fact that all debate was "educational " campaign material, since there was no hope of getting the two houses to agree on the tariff, made the discussion more rather than less bitter. All phases of the question were gone into but the main contention of the Democrats was the necessity

${ }^{1}$ Cong. Rec., 50 C., I S., p. 3057.

${ }^{2}$ House Rep., 50 C., I S., no. 1496. 
for revenue reduction, while that of the Republicans was that the bill was a step toward free trade and involved the overthrow of the protective system. Two Republicans, Fitch of New York and Nelson of Minnesota, spoke in favor of the bill. ${ }^{1}$ No Democrat spoke against the bill as a whole although several, among them Randall, offered amendments raising rates in specific schedules. Before the Mills bill was reported, Randall had introduced a bill providing for a reduction of $\$ 75,000,000$ in internal revenue duties and $\$ 20,000,000$ in customs, which had been referred to the ways and means committee without debate. ${ }^{2}$ On the final passage of the Mills bill he was absent because of illness but sent a letter asking for a pair. announcing that if he were present he would vote against the bill. ${ }^{3} \mathrm{He}$ was unable, however, to hold those who had previously followed his lead on the tariff.

The Democratic national convention met in June while the bill was still before the House. Nearly half of their platform was devoted to the tariff, and in a resolution adopted separately from the platform the Mills bill was specifically endorsed. ${ }^{4}$ This meant that Cleveland had succeeded in making tariff reduction a party issue. On the final passage of the Mills bill in the House the vote was I62 to I47, the majority containing three Republicans and two Independents and the minority four Democrats. ${ }^{5}$

The Republicans in their national platform of 1888 declared themselves to be " uncompromisingly in favor of the American system of protection " and protested against "its destruction as proposed by the President and his party."

${ }^{1}$ Cong. Rec., 50 C., I S., pp. 2504, 4277.

${ }^{2}$ Ibid., p. 1976.

${ }^{3}$ Ibid., p. 6660.

${ }^{4}$ Stanwood, Presidency, p. 468.

${ }^{5}$ McPherson, I888, p. 165. 
They asserted that they would effect all needful reduction in the revenue by the repeal of all taxes on tobacco and upon spirits used in the arts and for industrial purposes, and further, "If there shall still remain a larger revenue than is requisite for the wants of the government, we favor the entire repeal of internal taxes, rather than the surrender of any part of our protective system." ${ }^{1}$ In spite of this seemingly unequivocal declaration against any reduction whatever in customs duties, the finance committee of the Senate to which the Mills bill had been referred brought in in October, as a substitute for it, a bill reducing rates on sugar, adding to the free list certain articles not produced in the country and reducing internal taxes. ${ }^{2}$ The estimated reduction of the revenue was $\$ 6_{5}, 000,000$. The introduction of this bill was simply for political effect. Both the majority and the minority reports were stump speeches devoted mainly to an attack on and a defense of the Mills bill.

The campaign was conducted almost entirely on the issue of the tariff and the opinion was general that Cleveland's stand on the question was the main factor in his defeat. ${ }^{3}$ Throughout the campaign, however, as in the previous discussion in Congress, there was no agreement between the parties as to just what the issue was. The Democrats declared that it was simply a question of reducing the surplus by reducing tariff duties. The Republicans insisted that it was a question of whether free trade or protection was to be the policy of the country. This attitude on the part of the Republicans looks very much like an attempt to becloud the issue. It is true that Cleveland in his message used arguments which if carried to their logical conclusion would lead to free trade, but the arguments of the protectionists

${ }^{1}$ Stanwood, Presidency, p. 473.

${ }^{2}$ Sen. Rep., 50 C., no. 2332.

${ }^{3} C f$. newspapers and periodicals, Nov. I888. 
if carried to their logical conclusion would lead to the complete prohibition of imports. The point is that Ceveland did not carry or attempt to carry his arguments to their logical conclusion. He was simply arguing for a reduction of tariff duties, a step to which both parties were pledged. Any reduction in the tariff might be called a step toward free trade, but a step toward a certain policy does not necessarily involve the adoption of the policy. The Mills bill would have accomplished what the Republicans had promised to do in I884. Its rates were no lower than those often recommended by Republicans or by the tariff commission of 1883 .

While the Democrats did not succeed in reducing the tariff, they did perform a service to the country in partially clarifying the issue. Their action drove the Republicans definitely into the position of supporting high rates as a permanent policy and of resisting all attempts at reduction. The Democrats were definitely committed to reduction, although there might be doubt as to how far they would go. This clarification of the issues must be considered as a positive accomplishment of the Democrats. Here again Cleveland must be given the credit. It was he that forced the issue and compelled his party to redeem its platform pledges.

In the list of positive accomplishments of Cleveland's administration should be placed the change in policy in regard to the public lands. A large part of the public lands had fallen into the hands of speculators and corporations through evasion of the land laws and through leases made by railroads contrary to the terms of their grants. Both parties had been promising for years to reclaim the national domain for the use of actual settlers but nothing had been done. Congress passed an act in July, I888, forfeiting all such lands in railroad grants as lay along the right of way where the railroads were not yet completed. An amendment 
which would forfeit all grants to railroads where the roads had not fulfilled their contracts within the time limit received considerable support from Democrats but not enough for its adoption. ${ }^{1}$ By enforcing this law, by careful examination of other titles and by forfeiture of titles in cases of false entries and fraudulent claims over $80,000,000$ acres were restored to the public domain during Cleveland's administration. ${ }^{2}$

The navy department had been, ever since the civil war, a favorite field for spoilsmen. Appropriations had been wasted and the navy was obsolete and inefficient. President Arthur had aroused interest in the condition of the navy and a program of rehabilitation was started which Secretary Whitney carried on and extended during Cleveland's term. ${ }^{3}$

Republican control of the Senate throughout the period made impossible the passage of any strictly partisan legislation. Moreover, no question of importance, except the tariff, developed on which the Democrats presented a united front or which could really be called a party issue. There were, however, several sound laws passed, which, while nonpartisan in character, had Democratic support and may be placed on the credit side of the Democratic account. Among them were the Presidential succession act, ${ }^{4}$ the electoral count act, ${ }^{5}$ the repeal of the tenure of office act, ${ }^{6}$ the Dawes Indian act ${ }^{7}$ and the interstate commerce act. ${ }^{8}$ The bill for the repeal of the tenure of office act was introduced in the

${ }^{1} \mathrm{McPherson,}$ I888, p. 138.

Report of Sec. of Int., I889; Richardson, vol. viii, p. 795.

${ }^{3}$ Reports of Sec. of Navy, 1886, I889; Peck, Twenty Years, p. 65.

${ }^{4} U$. S. Stat. at Large, ch. 4 , 1886.

${ }^{5}$ Ibid., ch. 90, 1887.

'Ibid., ch. 353, I887.

"Ibid., ch. II9, I887.

${ }^{8}$ Ibid., ch. I04, I887. 
Senate by Senator Hoar but its supporters in both houses were mainly Democrats. ${ }^{1} \quad$ The Dawes act, which followed the lines of the President's recommendations in his first message, ${ }^{2}$ provided for the allotment in severalty of the land of any Indian reservation to the individual members of the tribe at the discretion of the President and also for the attainment of citizenship by Indians receiving allotments. The act marks the beginning of the policy of treating the Indian as a responsible person rather than a pauper and has been abundantly justified by the results.

Railroad abuses which followed the period of extensive construction of the sixties and seventies had aroused a demand, especially strong in the Middle West, for federal regulation of railroads. Bills had been introduced in every Congress during the period and the Democratic House in I 874 and again in 1878 had passed a bill providing for federal control. Reagan of Texas, the author of the bill of I878, was the leader of the movement in the House and continued to urge his bill in later Congresses. This bill, which came to be looked upon as the Democratic bill, providing for definite regulation of rates and the prohibition of certain abuses, was passed by the House in 1885 . The Senate passed another bill providing for a commission which had power merely to investigate and advise. ${ }^{3}$ In 1886 the Supreme Court in the Wabash decision ${ }^{4}$ decreed that a state had no power to regulate traffic which went beyond its borders. This increased the demand for federal regulation. Cleveland called attention to the necessity for it in his message of I886 and at the next session of Congress both

${ }^{1}$ McPherson, 1888, p. 46.

${ }^{2}$ Richardson, vol. viii, p. 355 .

3 Dewey, Nat. Probs., ch. vi; Johnson, Am. Railway Transportation, p. 317.

${ }^{4}$ II 8 U. S. 557. 
houses adopted the compromise which the conference committee reported. The bill as enacted provided that charges must be reasonable and schedules of rates must be public, prohibited rebates and pools and made it illegal to charge more for a short haul than for a long haul over the same line. It created a commission of five members with power. to administer the law, but failed to insure to the orders of the commission the force of the orders of a court.

The bill on its final passage received a large majority in both houses. $^{1}$ It was a proposition which no politician would care to vote against if a vote could not be avoided. While the bill cannot be called a partisan measure, the Democrats should get considerable credit for it. Public: opinion was bound to force some legislation sooner or later, but it was largely due to the Democrats that it came when it did and that it was as effective as it was. Many Republicans, while not opposing it openly in Congress or in the press, proposed amendments the purpose of which was to make the bill of little practical effect. ${ }^{2}$ Cleveland's appointments to the commission were approved by all parties. ${ }^{3}$.

The four years of Cleveland's administration were years of widespread discontent among the workingmen of the nation. The spectacle of increasing poverty in the midst of increasing wealth made labor feel that it was not getting its share of the prosperity and made it ready to listen to anyone with a remedy to suggest. Strikes and boycotts were frequent and violence in connection with labor troubles became more and more common. The 68,000 votes polled by Henry. George as the single-tax candidate for mayor of New York. City in 1887 are an indication of the spirit of the times.

\section{${ }^{1}$ McPherson, I888, p. I3.}

${ }^{2}$ McPherson, 1886, p. 136; Public Opinion, Jan. 8, 1887; N. Y. Tribune, Jan. 3, 1887.

${ }^{3}$ Public Opinion, April 2, I887. 
Cleveland in his various messages urged reduction of the tariff as a means of making labor more contented, and in a special message of April 22, 1886, he recommended the creation of a permanent commission for the voluntary arbitration of labor disputes. ${ }^{1}$ Congress did not accept this suggestion but later passed a bill providing for settlement of disputes between railroads and their employees. ${ }^{2}$ Other labor legislation of the period included an act establishing a department of labor, an act prohibiting any officer of the grovernment to hire out the labor of prisoners of the United States, an act providing for the incorporation of national trade unions and an act supplementing the Chinese exclusion1 act. The votes on all these bills were non-partisan, sany of them being passed without a division. ${ }^{3}$ There was no issue between the parties on these questions, as neither party had any definite policy toward labor or any program with which to meet the growing labor unrest.

The labor troubles of Cleveland's administration were a portent that the questions of the relation of labor and capital and of the attitude of the state toward each were to play a prominent part in American politics in the future. As the Republican party was becoming more definitely the party of Jarge financial interests, it might have been expected that the Democratic party would develop into a party which would champion the rights of the wage-earner against the rights of capital. The Democratic policy, or rather lack of policy, toward the labor situation made it clear that this was not to be the case. The Democrats could be depended upon to iend a more sympathetic ear than the Republicans to proposals to take away special privileges such as tariffs or land grants and to curb the more flagrant abuses of capital, but

Richardson, vol. viii, p. 395.

$=$ U. S. Stat. at large, ch. 1063,1888 .

McPherson, I886, 1888 , passim. 
on the fundamental question of the relation of the state to private property the parties differed in details rather than essentials. Both parties were controlled by and in the interests of capitalists. However sincere either was in its protestations of friendship for labor, the attitude was one of friendship rather than partnership. Labor was to be treated as a ward; its benefits were to be a by-product of the benefits to capital. There was no idea among the Democrats any more than among the Republicans of giving labor an effective voice in the party councils. The reputation of being a "safe" party on questions affecting labor and capital doubtless strengthened the Democrats but it drove into the Populist and Socialist movements those who desired something more than a "safe" policy.

The positive accomplishments of the Democrats during their four years of control may be summed up briefly. The laws enacted were few but they were necessary and sound. New policies in regard to the public lands, the Indians and the regulation of railroads were instituted. The principle of civil service reform was maintained and extended. The question of tariff reduction was forced to the front and an issue, tolerably clear, was drawn between the parties.

The main achievements of the Democrats, however, were negative rather than positive. They showed that they had accepted the results of the war, that they were not plotting the reestablishment of slavery nor the overthrow of the Union. They showed that the everyday affairs of the country went on much the same as when their opponents were in power: business was not disturbed; the currency was not debased; public obligations were not repudiated. They proved that their standards of administration were on the whole as high as those of the Republicans, that neither party had a monopoly of ability. In short, the Democrats had again become respectable. They had put themselves on 
a basis of equality with the Republicans where real issues could be discussed and decided on their merits.

Cleveland was responsible for a large part of the achievements of the Democrats, both negative and positive. He insisted from the start that the southern issue was dead, that the South should receive its due but no more than its due. He discouraged any inclination that his party might have had for action that would debase the currency or impair the credit of the government. Standing almost alone in his party for civil service reform, he restrained the spoilsmen, kept the principle of reform alive and extended it in practice. It was his bold action that made an issue of the tariff question. He was much the same sort of President as he had been governor and mayor-a hard-headed business man, practical, honest, direct, unimaginative, hardworking, never brilliant but never erratic. In spite of his limitations, his lack of experience, and the difficulties of his position, Cleveland in his first administration fairly earned an honorable place among our Presidents.

The question as to whether the results justified the action of the Mugwumps is more difficult since it involves a speculation as to what might have happened had the Republicans won in 1884 . The Independents were disappointed with Cleveland. Civil service reform did not make the progress that they had hoped and expected that it would. Judging from later events, however, it made fully as much progress as it would have been likely to make under a Republican administration and probably as much as could have reasonably been expected under the circumstances. The Mugwump movement itself attracted attention to the reform and did a great deal for that education of public opinion, on which all sound progress depends. After all, the Independents, with the possible exception of a few fanatics among them, were interested in civil service reform 
not as an end in itself but as a means of getting better government. The fact that a revolt caused by dissatisfaction with party methods and with the character of the party candidate had been instrumental in the defeat of that party. must make for better government in its effect on those who controlled party policies and selected party candidates. Indirectly also the Mugwump movement contributed to better government by helping to give the Democratic party an opportunity to show that it was as capable of administering the government as was the Republican party.

The reestablishment of the Democratic party as a real rival of the Republican must be considered the main result of the return of the Democrats to power. Hardly less important was its effect in solidifying the nation. If there was to be a real reunion in spirit the South as well as the North must forget the past. The South could not forget the past as long as the party which it believed to be the author of all its woes seemed to have permanent control of the national government. Southerners could not feel that they were responsible partners in the government as long as they were excluded from all share in the administration of it. A period of Democratic control was a necessary step in the restoration of respect and confidence between the North and South. 




RETURN CIRCULATION DEPARTMENT

TO $\rightarrow 202$ Main Library

\begin{tabular}{l|l|l}
\hline $\begin{array}{l}\text { LOAN PERIOD 1 } \\
\text { HOME USE }\end{array}$ & 2 & 3 \\
\hline 4 & 5 & 6 \\
\hline
\end{tabular}

ALL BOOKS MAY BE RECALLED AFTER 7 DAYS

1. month loans may be renewed by calling 642.3405

6-month loans may be recharged by bringing books to Circulation Desk

Renewals and recharges may be made 4 days prior to due date

\section{DUE AS STAMPED BELOW}

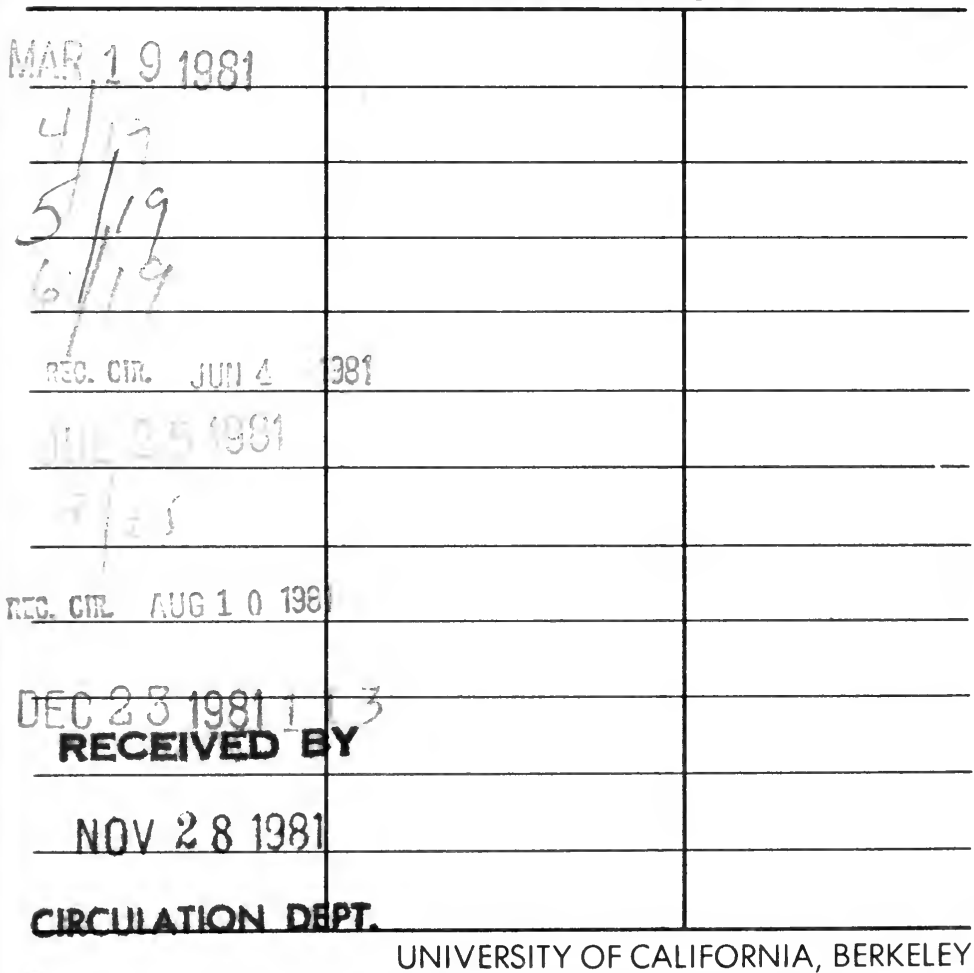

FORM NO. DD6, 60m, 3/80 BERKELEY, CA 94720

HEV Sin: YKU + $I \cdots$ 
Lis u-

$\pm$

$H=$

THE UNIVERSITY OF CALIFORNIA LIBRARY 


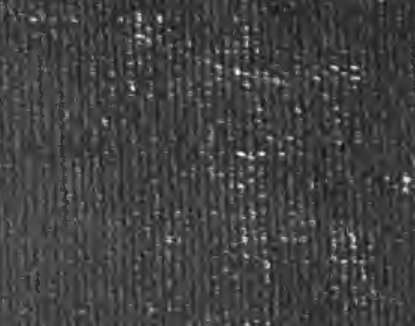

\section{6)} mond H. (3)

(5)

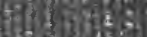

a) 3 3)

2.

y.th

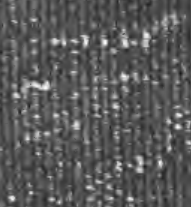

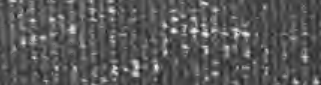

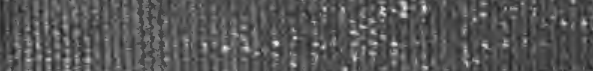

If

N19:

Hal

1

3

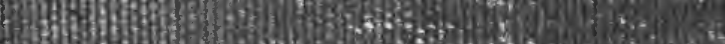

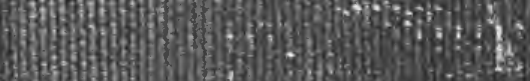

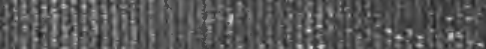

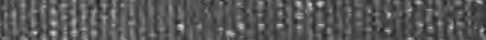

forits

stuth

4. 